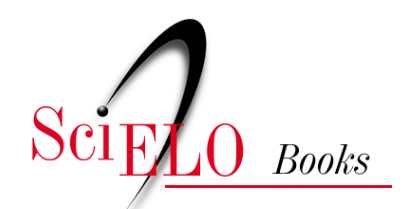

\title{
Educação das relações étnico-raciais avaliação da formação de docentes
}

\author{
Dalila Fernandes de Negreiros
}

\section{SciELO Books / SciELO Livros / SciELO Libros}

NEGREIROS, D.F. Educação das relações étnico-raciais: avaliação da formação de docentes [online]. São Bernardo do Campo, SP: Editora UFABC, 2017, 172 p. ISBN: 978-85-68576-94-6. https://doi.org/10.7476/9788568576946.

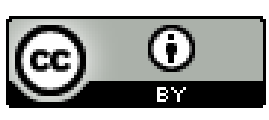

All the contents of this work, except where otherwise noted, is licensed under a Creative Commons Attribution 4.0 International license.

Todo o conteúdo deste trabalho, exceto quando houver ressalva, é publicado sob a licença Creative Commons Atribição 4.0.

Todo el contenido de esta obra, excepto donde se indique lo contrario, está bajo licencia de la licencia Creative Commons Reconocimento 4.0. 
Educação das Relações Étnico-raciais

avaliação da formação de docentes 


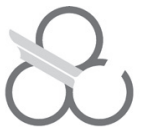 \\ UFABC}

\section{UNIVERSIDADE FEDERAL DO ABC}

Klaus Werner Capelle - Reitor

Dácio Roberto Matheus - Vice-Reitor

\section{Editora da UFABC}

Coordenação

Adriana Capuano de Oliveira

Conselho Editorial

Ana Claudia Polato e Fava

Ana Paula de Mattos Arêas Dau

Andrea Paula dos Santos Oliveira Kamensky

Artur Zimerman

Christiane Bertachini Lombello

Daniel Pansarelli

Daniel Zanetti de Florio

Douglas Alves Cassiano

Fernando Luiz Cássio Silva

João Rodrigo Santos da Silva

Júlio Francisco Blumetti Facó

Luciana Pereira

Marcelo Augusto Leigui de Oliveira

Márcia Helena Alvim

Margarethe Born Steinberger-Elias

Mario Alexandre Gazziro

Rodrigo de Alencar Hausen

Sidney Jard da Silva

Sílvia Dotta

Equipe Técnica

Cleiton Klechen

Natalia Gea 
Dalila Fernandes de Negreiros

\section{Educação das \\ Relações Étnico-raciais \\ avaliação da formação de docentes}

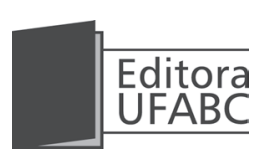

São Bernardo do Campo - SP

2017 
(C) Copyright by Editora da Universidade Federal do ABC (EdUFABC)

Todos os direitos reservados.

\title{
Equipe Técnica sob Coordenação da Gráfica e Editora Copiart
}

\author{
Revisão textual e Normalização ABNT \\ Marcia Regina Pereira Sagaz \\ Projeto Gráfico, Diagramação e Capa \\ Rita Motta \\ Impressão \\ Gráfica e Editora Copiart
}

\section{CATALOGAÇÃO NA FONTE \\ SISTEMA DE BIBLIOTECAS DA UNIVERSIDADE FEDERAL DO ABC \\ Responsável: Kátia Ellen Chemalle CRB: 8/7720}

Negreiros, Dalila Fernandes de

Educação das relações étnico-raciais : avaliação da formação de docentes / Dalila Fernandes de Negreiros - São Bernardo do Campo, SP : EdUFABC, 2017.

xvi, 172 p. : il.

ISBN: 978-85-68576-72-4

1. Ações afirmativas - Ensino Superior. 2. Relações Étnicas e Raciais. 3. Formação de professores. 4. Negros - Educação. 5. Políticas Públicas - Ensino Superior. I.Título

CDD 22 ed. -379.2

\section{EDITORA ASSOCIADA
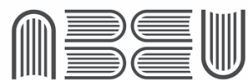 \\ Associação Brasileira das Editoras Universitárias}




\section{Agradecimentos}

Este livro, assim como o conjunto das recentes reflexões teóricas sobre racismo no Brasil e as formas de enfrentamento, é resultado de esforços coletivos de pessoas negras.

Começo agradecendo à minha mãe Darcy Negreiros por ter propiciado simplesmente tudo o que era possível, necessário e importante... sempre.

Às minhas tias Ana Maria Negreiros Santos, Sarah Negreiros, Rhodes Negreiros, Marli Negreiros, Maria Eunice Negreiros, Leni Negreiros e Diva Luci Pio.

Ao meu irmão Diogo Bruno Fernandes de Negreiros e a toda a minha família.

À Editora UFABC pela oportunidade de publicar esta reflexão.

À Fiocruz e ao IPEA que me proporcionaram um curso de mestrado profundo e instrumental que contribui para esta e para outras reflexões.

À minha orientadora no mestrado, Profa. Dra. Maria Aparecida Abreu, e aos demais membros da banca examinadora, Profa. Dra. Luciana Jaccoud e Prof. Dr. Frederico Barbosa.

À Sra. Bárbara Rosa e ao Sr. Roberto Sobral, do Ministério da Educação, pelo auxílio na coleta dos dados institucionais.

Ao Sr. Carlos Alberto Júnior pelo apoio na coleta dos dados na Secretaria de Políticas de Promoção de Igualdade racial. 
À Luiza Bairros e Ana Flávia Magalhães Pinto.

A todas e todos os EnegreSeres.

A Artur Antônio e todos do Nosso Coletivo Negro.

Às amigas e aos amigos queridos, Fabiana, Memê, Bia, Sara, Tawana, Letícia, Janaína, Allyne, Murilo, Paulo Victor, Felipe, Majoy, Dudu, Ingrid, Paula, Ana e Roseli Negreiros Santos (in memorium). A Samir Kolawole Akani Landou, por ter sido efetivamente minhas mãos e pernas enquanto eu escrevia o livro, e pelo companheirismo. 


\section{Prefácio}

Em Educação das Relações Étnico-raciais: avaliação da formação de docentes a pesquisadora e ativista social Dalila Negreiros analisa a formação de docentes na política de educação das relações étnico-raciais a partir da Lei n. 10.639/2003, por meio da avaliação de dois programas inaugurais do Ministério da Educação (MEC) intitulados Educação Africanidades Brasil (Africanidades) e Programa de Ações Afirmativas para a População Negra nas Instituições Federais e Estaduais de Educação Superior (Uniafro). Dalila explora os objetivos, informações programáticas, processos e resultados alcançados por esses programas. Igualmente, avalia como tem sido a coordenação federal desta política, e ainda recomenda indicadores de formação para o aprimoramento da política no campo da igualdade étnico-racial.

A autora nos mostra que a educação das relações étnico-raciais transforma-se em política pública a partir do ano de 2003, num período especialmente profícuo para o avanço das políticas de combate ao racismo no governo federal, sendo que as ações que visem a sua consecução devem considerar um conjunto de diretrizes para o enfrentamento à discriminação racial e à promoção da valorização da diversidade em território nacional, além de estabelecer articulação com os sistemas de ensino. Em que pesem alguns avanços no campo da política em prol da igualdade racial no país, 
sabemos que o combate ao racismo em nossa sociedade ainda não se constitui como elemento fulcral na agenda do Estado brasileiro, uma vez que as disparidades raciais ainda são enormes. Consecutivamente, os escassos programas de criação e/ou inflexão de políticas voltadas para a população negra não são percebidos como relevantes para o fortalecimento da nação. Na realidade, em muitas situações identifica-se que os esforços empreendidos nas últimas décadas têm sido interpretados - tanto no nível das instituições governamentais quanto na sociedade em geral - como ações que privilegiam apenas a população negra brasileira e não o conjunto da sociedade. Nesse sentido, o trabalho da pesquisadora Dalila traz à luz questionamentos e formulações sobre um problema que é político e também moral em nossa sociedade.

Para além disso, a fim de compreendermos o alcance dessa obra, devemos considerar que embora os estudos sobre a avaliação de políticas públicas no âmbito da educação sejam um tópico valorizado e explorado na construção de conhecimento, os estudos voltados para a análise das políticas públicas dirigidas ao combate do racismo e seus derivados no âmbito das instituições públicas são ainda pouco incentivados e, portanto, sua existência segue incipiente. Não por acaso, poucos e frágeis são os elementos dos quais dispõem os gestores para compreenderem a dinâmica de construção dessas políticas e todo processo de execução e avaliação necessário para medir eficiência e eficácia de tais ações, tanto em suas características unitárias quanto das articulações entre os vários programas no MEC, bem como de sua renossância na sociedade.

Diante desse cenário, Dalila confirma a ainda presente necessidade de uma ação coesa e potencializadora da implementação de políticas de combate ao racismo e de valorização da história e cultura africana e afro-brasileira, visto que essa não se configura 
como parte integrante de uma política mais ampla de inserção e implementação dessa temática nos sistemas de ensino nos estados e municípios. A autora também identifica lacunas e aponta limites ainda não superados no âmbito da formulação e da implementação de políticas públicas para formação de professores para a educação das relações raciais, história e cultura afro-brasileira e africana.

$\mathrm{O}$ que realmente precisamos diante desse contexto? Necessitamos de ter uma cidadania de fato, a qual deve ser forjada desde o interior do próprio MEC para assim atingir os sistemas de ensino como política de estado em prol da igualdade racial. Somente assim, teremos um desenvolvimento socioeconômico e cultural do Brasil como uma nação. Se, por um lado, o trabalho de Dalila nos coloca a par de estratégias que se mostraram ineficazes, por outro lado, nos leva a conhecer as primeiras tentativas do MEC em construir subsídios e fomentar experiências para a implementação da Lei n. 10.639/2003. Esse livro nos estimula a perceber perspectivas inovadoras, que resultaram em erros e acertos na implementação de políticas públicas para a consecução da citada lei. Mais importante, a leitura nos faz pensar sobre possíveis limites naturais da eficácia e eficiência das políticas de combate ao racismo; na medida em que formuladores e também receptores dessas políticas, mais especificamente os profissionais da educação - gestores e professores -, são, não somente os elementoschave de uma política de educação antirracista, mas em sua maioria os perpetradores de atitudes e práticas racistas no interior dos sistemas de ensino, bem como da sociedade mais ampla. Portanto, seriam essas estratégias mais eficientes se tratassem de tema aprazível entre os profissionais da educação?

Como ex-coordenadora da Coordenação Geral de Diversidade e Inclusão (CGDI/SECAD) do MEC, de 2004 a 2006, estando à frente do programa Africanidades Brasil, aqui analisado por 
Dalila, sou levada a relembrar os inúmeros esforços realizados por minha equipe para suprir todos os déficits na condução da política: capacidade humana, política, material e monetária, tanto no interior do MEC, de forma geral, quanto na equipe direta da Coordenação Geração de Diversidade e Inclusão Educacional - CGDI. Além dos mesmos déficits identificados nos parceiros que integravam às Secretarias Estaduais de Educação (SEE) e as Secretarias Municipais de Educação (SEM). Da experiência fica a certeza de que políticas para a implementação da Lei n. 10.639/2003 constituem uma questão pluridimensional que requer pensar cuidadosamente não somente sobre o alcance de resultados, mas também sobre a criação de indicadores que possam medir com precisão a extensão desses resultados ao longo do tempo. Certamente, é fundamental que haja uma coordenação eficaz entre a gestão organizacional, a gestão política e a gestão programática, assim como a atenção necessária ao cotidiano das instituições que impõem aos gestores ações imediatas relacionadas aos problemas práticos e burocráticos do cotidiano da administração pública. A gestão política sobre esse tema torna-se algo ainda mais complexo quando são consideradas as disputas político-partidárias, a resistência ativa de muitos gestores quanto à necessidade de implementação de políticas com base nas especificidades colocadas para o combate ao racismo na sociedade, sem contar a negação perversa da existência do racismo estrutural em nossa sociedade pela maioria deles. Assim, o que nasce como uma ação de efetivação de uma lei se transmuta para um cenário de confronto a questionamentos persistentes sobre a legalidade da lei e a existência ou não do racismo e dos seus prejuízos na sociedade brasileira.

Talvez, o trabalho de Dalila seja um alerta para a sociedade de que o fosso entre a formulação das políticas e os resultados alcançados não é meramente lacunar. Quem sabe sejam esses os elementos 
integrantes da ordem das deficiências naturais intrínsecas às políticas de transformação de componentes racistas e discriminatórios fortemente arraigados em nossa sociedade. Esta obra, certamente, nos direciona a pensar sobre o quanto os caminhos abertos para o cumprimento dessa legislação ainda são frágeis e pouco eficientes para a potencialização do processo de formação de professores, para o estabelecimento de um processo de ensino-aprendizagem equânime, bem como para o estabelecimento de igualdade racial como um todo. $\mathrm{O}$ trabalho de Dalila deixa evidente que não houve verticalização das políticas do MEC no que tange a formação de professores. Uma das indagações a ser feita seria: como alcançar e formar professores quando esses estão convictos de que: a) não são racistas, b) não existe racismo na sociedade e menos ainda nas escolas, e c) de que o conhecimento ofertado não é apenas irrelevante, mas também responsável por conturbar o fazer profissional de professores e ainda "carregar" o currículo escolar? Talvez as respostas a essas perguntas possam romper com a negação do racismo. Assim, finalizamos a leitura do trabalho de Dalila com inúmeros questionamentos e indagações, mas também com a certeza de haver limites e possibilidades da gestão de uma política pública que, para além de sua existência no arcabouço legislativo, não goza de prestígio social e tampouco tem respaldo para se afirmar como anseio de parcela significativa dos profissionais que integram os sistemas de ensino.

Mas, muito mais importante do que isso, esse trabalho lança convite para um desdobramento a instituições e pesquisadores interessados em ampliar conhecimento qualitativo sobre a temática, verificando a ressonância das políticas na sociedade, buscando responder questões mais amplas que fogem ao objetivo direto da política, articulando outros programas gerais e ligados à formação 
de professores, e questionando como essas políticas que foram implementadas acabaram não tendo continuidade ou aprimoramentos. Enfim, o estudo de Dalila prova que é imperioso expandir e sistematizar a avaliação das políticas públicas em prol de uma educação antirracista.

\section{Eliane Cavalleiro}

Doutora em Educação pela Faculdade de Educação da Universidade de São Paulo. Ex-professora adjunta da Faculdade de Educação da Universidade de Brasília. Pesquisadora afiliada ao Centro de Estudos Latino-Americanos - CLAS, Stanford University 


\section{Sumário}

INTRODUÇÃO 1

Capítulo 1

POLÍTICAS RACIAIS: A IGUALDADE POSSÍVEL ..............................17

1.1 A institucionalização da luta antirracista ......................... 21

1.2 Promoção da igualdade racial: as ações e omissões ......... 30

1.2.1 Políticas compensatórias .........................................42

1.2.2 Políticas repressivas................................................. 45

1.2.3 Políticas valorizativas ............................................. 48

Capítulo 2

EDUCAÇÃO DAS RELAÇÕES ÉTNICO-RACIAIS (S)EM PERSPECTIVA ... 57

2.1 Educação das relações étnico-raciais: breve histórico ......... 61

2.2 Panoramas, painéis e indicadores..................................71

2.2.1 Educação básica ................................................... 71

2.2.2 Educação superior ............................................... 77

Capítulo 3

AFRICANIDADES E UNIAFRO: EXPERIÊNCIAS INCONCLUSAS ..........93

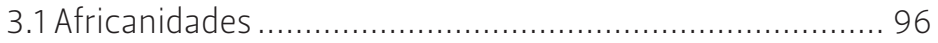

3.1.10 Projeto Educação Africanidades Brasil (Africanidades) .. 96

3.1.2 Execução e resultados ....................................... 100

3.1.3 Uma experiência no Africanidades ..........................101

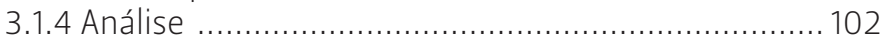

3.2 Programa de Ações Afirmativas para a População Negra

nas Instituições Federais e Estaduais de Educação Superior

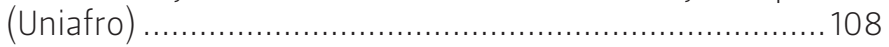

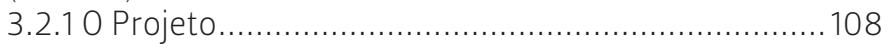

3.2.2 Execução e resultados.......................................... 113 


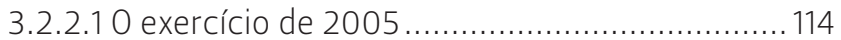

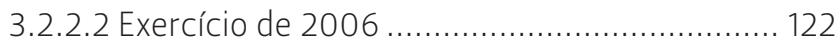

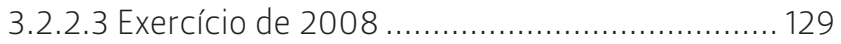

3.2.3.4 Exercício de 2009 ....................................... 132

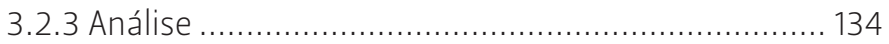

3.2.3.1 Dificuldade de celebração e pagamento dos projetos..................................................137

3.2.3.2 Incipiente estágio de articulação entre os NEAB e a baixa institucionalização dos núcleos nas instituições públicas de ensino superior ......... 139

3.2.3.3 Dependência do convênio com o MEC para a continuidade dos projetos. 


\section{Introdução}

A despeito dos 120 anos da abolição da escravatura, o Brasil ainda possui uma grande diferença entre as condições de vida de pessoas negras e pessoas brancas. ${ }^{1}$ Essa diferença perdura ao longo das décadas em virtude de uma série de práticas discriminatórias fundamentadas no racismo.

Para combater essas práticas e aproximar as condições de vida da população negra às da população branca, diversas políticas públicas têm sido elaboradas e implementadas no Brasil. Essas políticas partem do diagnóstico de que a sociedade brasileira é racista, buscando combater o racismo e seus efeitos, haja vista que esse racismo permeia comportamentos sociais e institucionais.

Uma das questões cerne para a sobrevivência, produção e reprodução do comportamento racista brasileiro refere-se ao processo de construção da história e identidade nacional, que inviabilizou

\footnotetext{
${ }^{1}$ Segundo o Censo Demográfico de 2010, em relação aos itens Características da População e Domicílios, apurou-se que a população negra (considerada pela junção das raças/cores preta e parda) é a maioria da população brasileira, chegando a 50,7\%. Contudo, quando examinamos a população a partir de seus indicadores sociais, a proporção não permanece a mesma. A população negra constitui: $66 \%$ do contingente de pessoas não alfabetizadas com mais de cinco anos, $70 \%$ das pessoas que recebem menos de $1 / 4$ do salário mínimo e possuem o rendimento médio mensal das pessoas com mais de 10 anos de aproximadamente $55 \%$ do rendimento de pessoas brancas (rendimento de pessoas brancas: $\mathrm{R} \$ 1.535,94$, pretas: $\mathrm{R} \$ 833,21$ e pardas $\mathrm{R} \$ 844,66)$ (IBGE, 2010).
} 
grupos não hegemônicos e vozes dissonantes da aparente harmonia da convivência entre os diversos grupos formadores do povo brasileiro (DEGLER, 1976; SKIDMORE, 1979; SODRÉ, 1999; MUNANGA, 2004).

A construção dessa história e dessa identidade nacional, empreendida a despeito da população negra, conformou a educação nacional e seu currículo, reforçando a exclusão da população negra de espaços de representatividade, de visibilidade e de poder.

A fim de combater essa prática, foi instituída a Lei n. 10.639, de 9 de janeiro de 2003, a qual tornou obrigatório o ensino de história e cultura africana e afro-brasileira. Consta da lei que:

[...] o conteúdo programático a que se refere o caput deste artigo incluirá o estudo da História da África e dos Africanos, a luta dos negros no Brasil, a cultura negra brasileira e o negro na formação da sociedade nacional, resgatando a contribuição do povo negro nas áreas social, econômica e política pertinentes à História do Brasil. (BRASIL, 2003).

Indicando a inclusão desse "novo" conteúdo no currículo escolar, o qual deveria somar-se aos demais presentes na Lei de Diretrizes e Bases da Educação, Lei n. 9.394, de 20 de dezembro de 1996 (LDB), em especial nas áreas da história do Brasil, literatura e artes, a Lei 10.639/2003 constitui um grande avanço para a discussão do combate ao racismo na educação e para a revisão dos conteúdos curriculares excludentes, não só em relação à população negra.

Promover uma educação inclusiva à população negra é um grande desafio. Questões relativas ao acesso à escola, como: há uma escola próxima? quanto se gasta para chegar até ela? quanto tempo se passa dentro dela? É possível conciliar o horário com o trabalho? colocam-se ao lado de outras, relativas ao currículo, como: o que é ensinado? para o que serve o que é ensinado? condiz com a realidade? 
Entende-se que todos esses fatores são possíveis causas da evasão escolar da população negra a partir do ensino médio. ${ }^{2}$ Ainda que essas questões estejam presentes na educação de toda a população, tornam-se ainda mais importantes quando consideramos a população negra, uma vez que, como já apontado nos dados, existe intersecção entre raça e classe, e há questões específicas no que tange à representação e à visibilidade da população negra.

A Lei 10.639/2003 foca essa inclusão no conteúdo ministrado, principalmente ao vislumbrar o currículo escolar como instrumento de difusão da subordinação racial, tentando inverter essa lógica para transformá-lo em instrumento da luta antirracista. Para promover o resgate da contribuição da população negra à história nacional e sua inclusão, seriam necessárias mudanças na formação dos docentes, nos livros didáticos, nos projetos político-pedagógicos das escolas, na avaliação da educação e, possivelmente, também deveriam ser adotados mecanismos indutores dessa inserção como a inclusão da temática nos conteúdos dos vestibulares.

Esse conjunto de ações recebeu a alcunha de educação das relações étnico-raciais ${ }^{3}$, a qual tem por objetivos possibilitar o

\footnotetext{
2 Segundo os dados do Censo Escolar 2010, enquanto a taxa de abandono escolar no Ensino Fundamental era de 3,1\%, o abandono escolar no Ensino Médio era de 11,6\%; a taxa de reprovação no Ensino Fundamental era 10,3\%, no Ensino Médio era 12,5\%; a distorção idade/série chegava a 23,6\% dos alunos no Ensino Fundamental, alcançando 37,8\% dos estudantes no Ensino Médio (MEC/ INEP/Censo Escolar, 2010). Porém, ao se analisar os dados da composição racial dos alunos em distorção na relação idade-série ou ausentes da escola, observa-se a predominância da população negra; entre os jovens de 15 a 17 anos, 85\% dos estudantes brancos frequentam a escola, enquanto somente $79 \%$ dos estudantes negros o fazem, e enquanto $58 \%$ dos estudantes brancos estão na série indicada para a sua idade, a proporção dos estudantes negros na mesma situação é de 39\%. (IBGE, PNAD, 2007)

3 Ao longo do trabalho, será adotada a grafia de étnico-raciais visto que de acordo com a Nova Ortografia o uso do hífen permanece para adjetivos compostos.
} 
reconhecimento de pessoas negras na cultura brasileira a partir de seu próprio ponto de vista, promover o conhecimento da população brasileira sobre a história do Brasil com a visão de mundo da população negra, formar os professores para ministrarem disciplinas que contemplem a perspectiva negra na história, cultura e sociabilidade do País, assim como saibam combater e discutir sobre o racismo e seus efeitos (dentro e fora do ambiente escolar), e finalmente propiciar a reeducação para relações étnico-raciais plurais e diversas.

É importante destacar que a educação das relações étnico-raciais é uma política pública que surge num período especialmente profícuo para políticas de combate ao racismo pelo governo federal, e tais ações se articulam por um conjunto de diretrizes para o enfrentamento ao racismo e para a promoção da população negra.

As iniciativas governamentais de promoção dessa política são coordenadas pela Coordenação-Geral de Educação das Relações Étnico-raciais do Ministério da Educação. Entre as competências dessa Coordenação-Geral está a promoção de ações para a formação de profissionais da educação a fim de qualificá-los a ministrar os conteúdos da educação das relações étnico-raciais e também a identificar e combater a discriminação racial no ambiente escolar. Entende-se que a formação de docentes é um dos principais eixos de ações para a educação das relações étnico-raciais tanto porque é efetivamente necessário habilitá-los para ministrar o conteúdo expresso pela legislação, quanto pela necessidade de mobilizá-los para o combate ao racismo na e por meio da escola.

Tendo isso em vista, em 2005 foram iniciados dois projetos com o objetivo de promover a formação docente nesses moldes:

\footnotetext{
Entretanto, esse entendimento não estava fixado quando boa parte da legislação sobre o tema foi promulgada, sendo encontrada nas citações também a grafia "etnicorracial".
} 
Programa Educação Africanidades Brasil (Africanidades), que contitui-se como um curso e visava à formação de docentes, e o Programa de Ações Afirmativas para a População Negra nas Instituições Federais e Estaduais de Educação Superior (Uniafro), que visa fortalecer os Núcleos de Estudos Afro-Brasileiros (NEAB) das instituições públicas de Ensino Superior, formar professores e elaborar materiais de apoio à educação das relações étnico-raciais.

O Africanidades teve somente uma edição, em 20064, enquanto o Uniafro tornou-se um dos principais programas da Coordenação-Geral de Educação das Relações Étnico-raciais.

Porém, quando da aprovação da Lei 10.639/2003, os mecanismos de implementação não foram estabelecidos. Somente em 2009 foi criado o Plano Nacional de Implementação das Diretrizes Curriculares Nacionais para a Educação das Relações Étnico-raciais e para o Ensino de História e Cultura Afrobrasileira e Africana.

Assim, durante um período de seis anos, não houve prazos, metas, nem um projeto claro de implementação com horizonte temporal e plano nacional, implicando que as iniciativas da implementação da educação das relações étnico-raciais fossem diversas e esparsas no tempo e no espaço.

Diante disso, propõe-se, com este trabalho, analisar a formação de docentes na Política de Educação das Relações Étnico-raciais a partir da Lei 10.639/2003, por meio de avaliação dos Programas Uniafro e Africanidades e, a partir disso, compreender como tem sido a coordenação nacional da Política, para, com isso, recomendar indicadores de formação para possibilitar melhoras nessa coordenação.

\footnotetext{
${ }^{4}$ Em 2006 houve a primeira formação de turmas do Curso Educação Africanidades Brasil. Contudo, no ano de 2007 foram contatados os alunos desistentes do curso para que o concluíssem e entregassem os trabalhos finais para a obtenção do certificado.
} 
Tal análise justifica-se na medida em que a proposição de um currículo escolar nacional que contemple a diversidade racial do País é, há muito, item central de pauta de diversas entidades do movimento negro. Parte dessa centralidade ocorre em virtude da crença de que o ensino a respeito da presença, da contribuição da população negra e da formação da identidade negra na história do Brasil é elemento-chave para o combate ao racismo e sua não reprodução. Analisar o processo de implementação da Política de Educação das Relações Étnico-Raciais é, assim, uma forma de avaliar parte significativa da construção de um projeto de sociedade que contemple a população negra em sua identidade.

Para Souza (2007), a principal distinção entre analisar políticas públicas e políticas sociais está no foco das pesquisas. Enquanto a pesquisa em políticas públicas tem a ênfase voltada ao andamento e ao desenvolvimento das políticas, as pesquisas em políticas sociais estariam mais interessadas em saber a relação entre os resultados apresentados frente à consecução do combate aos problemas sociais visados por essas políticas.

Theodoro e Delgado (2003) advertem que uma das questões cerne relativas às políticas sociais no Brasil é seu vínculo com o combate à desigualdade. Os autores indicam que o problema da desigualdade é histórico no País, sendo presente mesmo em momentos de crescimento econômico, indicando-se a necessidade de políticas sociais para sua consecução. Contudo, esses autores ressaltam que a ênfase dessas políticas tem-se concentrado no combate à pobreza, limitando a desigualdade em sua complexidade.

Para Draibe (1990), o histórico do estudo de políticas sociais no Brasil é recente, havendo duas grandes limitações: i) a fragmentação e setorialidade dos estudos e ii) a ênfase no diagnóstico em detrimento da prospecção. Segundo Souza (2007), a partir da década de 1990 há o ressurgimento do campo de políticas públicas 
no Brasil como área de conhecimento em virtude da necessidade de otimização dos gastos públicos e de equacionamento do desenvolvimento econômico com o desenvolvimento social.

Ainda que o estudo sobre as políticas sociais seja recente no Brasil, Santos (1987) indica que a grande gênese de sua formulação pelo Estado se deu no período de 1930 a 1943. Segundo o autor, de 1888 a 1931, haveria a impossibilidade de construção de um Estado de bem-estar social clássico no País em virtude da concentração do trabalho na atividade agrícola, ausência de mobilidade no trabalho e da repressão à organização dos trabalhadores na década de 1920.

A partir de 1930, com a revolução que culminou com a ditadura de Getúlio Vargas (1930-1945) e a organização e mobilização dos trabalhadores urbanos, há a conquista de políticas sociais por parte da classe trabalhadora organizada, constituindo aquilo que o autor denomina cidadania regulada. A cidadania regulada consiste na concessão da cidadania, em forma de acesso à proteção social, aos sujeitos inseridos no mercado de trabalho em ocupações reconhecidas e definidas em lei. Esse modelo de concessão de "benefícios" sociais por meio de inserção no mercado de trabalho somente teria sido transformado a partir da Constituição da República Federativa do Brasil de 1988, a qual transfere essas políticas da esfera do benefício para a do direito.

Draibe (1990) propõe uma análise de políticas sociais a partir das questões postas para o futuro, classificando o Estado de Bem-Estar Social como um sistema de regulação pública dos serviços sociais. Para Theodoro e Delgado (2003), o efetivo enfrentamento da desigualdade em sua plenitude e complexidade somente é possível se a ação pública tiver um escopo mais amplo. Assim, o combate à pobreza não poderia ser o objetivo único da política social, mas produto de um esforço mais geral e concertado da sociedade, no qual políticas de transferência de renda, assim como 
outras políticas mais estruturais, sejam parte integrante de um projeto nacional mais amplo de inclusão. Desse modo, para alcançar a inclusão dos grupos historicamente excluídos, como a população negra, as mulheres, os povos e comunidades tradicionais, entre outros, seriam necessárias políticas específicas.

Segundo Souza (2007), um dos modelos mais conhecidos de classificação de políticas públicas é o de Theodor Lowi (1972), o qual classifica as políticas como: i) distributivas, relacionadas às políticas que visam conceder beneficio a certos grupos ou regiões; ii) regulatórias, que determinam normas de funcionamento; iii) redistributivas, que redirecionam recursos de população mais abastada para população com menos condições financeiras; iv) constitutivas, que indicam os procedimentos a serem adotados.

A educação das relações étnico-raciais se caracteriza como política regulatória, uma vez que determina e cria condições para o ensino sobre a questão racial, especialmente a partir da Lei 10.639/2003, e também como política redistributiva no campo simbólico e cultural, uma vez que objetiva a valorização da história e cultura negra no País, propiciando à população negra o reconhecimento e a valorização da sua ancestralidade e dos valores culturais.

Assim, para analisar uma política com essas características é necessário tanto medir a adoção das normas fixadas a partir da legislação que embasa a educação das relações ético-raciais, quanto estimar se essas normas conduzem à execução do objetivo da política e, também, se o modelo de coordenação e execução da política são instrumentos de disseminação da valorização almejada.

Para o desenvolvimento de políticas públicas, essa avaliação da implementação da educação das relações étnico-raciais é importante na medida em que constitui um instrumento de avaliação que permite estender a análise desde os aspectos gerais do processo de identificação de uma demanda social, percorrendo 
todos os passos até a efetiva implementação da política pública que deveria dialogar com a mesma questão inicial. Também é relevante eventualmente observar as boas práticas, as vicissitudes e os aspectos necessários à implementação de uma política dessa natureza.

É imperioso indicar que essa política, que é ao mesmo tempo de educação e de promoção da igualdade racial, possui nessa dupla inserção, diversos elementos desafiadores para a análise de políticas públicas, tanto pela recente implementação quanto pela interinstitucionalidade que tais ações tendem a demandar.

\section{Metodologia}

Segundo Souza (2007), a área de análise de políticas públicas tem sua gênese na década de 1930 nos EUA. A tradição americana de análise é caracterizada pela visão da política como ação governamental não necessariamente vinculada essencialmente ao papel do Estado.

Para a autora, ao analisar uma política pública parte-se da concepção de que as ações idealizadas pela política são estruturadas com vistas à solução de um problema. Mas essas ações também são balizadas por ideias e interesses de diferentes atores relacionados à política. É também relevante destacar que a solução proposta ao problema não parte necessariamente de uma ação exclusivamente governamental, podendo contar com a cooperação de entidades da sociedade civil.

Segundo Souza, de modo geral, o olhar que guia a análise de políticas públicas assume a multiplicidade de fatores que influem nessas políticas, indicando a necessidade de uma análise holística. Assim, para a autora,

[...] pode-se, então, resumir política pública como o campo do conhecimento que busca, ao mesmo tempo, colocar 
o 'governo em ação' e/ou analisar essa ação (variável independente) e, quando necessário, propor mudanças no rumo ou curso dessas ações (variável dependente). (SOUZA, 2007, p. 69).

No caso específico da educação das relações étnico-raciais, esses fatores são expressos pela identificação de alguns problemas que essa política visa combater, como o racismo, a educação excludente e a formação deficitária da população no que tange aos temas africanos e afro-brasileiros.

A solução para esses problemas veio na forma da proposição da obrigatoriedade do ensino da questão racial sobre determinados parâmetros que garantam a valorização da história e cultura negras. Há, ainda, os interesses: i) da população negra, representada por diversas entidades do movimento negro que pautam essa demanda há décadas; ii) do MEC que é o órgão responsável pela coordenação de ações que garantam o objetivo da política; iii) dos docentes e das escolas, que são responsáveis pela execução da política; iv) do governo federal, que deseja demonstrar que tem executado ações para responder às demandas dos movimentos negros. Se por um lado há interesse da população negra em se ver representada no conteúdo escolar por meio de política pública específica, há também divergências entre os interesses dessa população e dos demais atores.

O MEC é responsável por coordenar a política educacional do País, mas não conta necessariamente com equipe e recursos financeiros robustos para a execução dessa política. No caso do Educação das Relações Étnico-Raciais, a ausência de recursos financeiros e/ou de pessoal impactaram no modelo de política adotado, ou seja, uma política rivaliza com as demais, pela disputa de recursos, de expertise e de decisão, dentro do MEC. 
O governo federal tem interesse em demonstrar a realização de ações, sem obrigatoriamente propiciar os meios de efetivação da promessa de inclusão expressa na legislação, porque para isso seria necessária uma priorização efetiva, por meio da disponibilização de recursos. Já na rede de educação básica, os docentes têm um conteúdo vasto e quase enciclopédico para ministrar, mas não contam, necessariamente, com formação e estrutura mínima que possibilite a inclusão dos novos temas.

Um dos modelos analíticos mais utilizados para a análise de políticas públicas é o ciclo da política, o qual prevê seis etapas constitutivas do processo de construção das políticas públicas, que são: definição da agenda, identificação das alternativas, avaliação das opções, seleção das opções, implementação e avaliação (SOUZA, 2007, p. 74).

A educação das relações étnico-raciais é uma demanda histórica do movimento negro no Brasil. ${ }^{5}$ Contudo, essa demanda só começou a entrar na agenda governamental de forma mais resolutiva a partir de 1995, em virtude dos desdobramentos da Marcha Zumbi dos Palmares, contra o Racismo, pela Cidadania e pela Vida, entre os quais se destaca a formação do Grupo de Trabalho Interministerial para a Valorização da População Negra (GTI População Negra), em 1996.

Como desdobramento das ações do GTI População Negra, em 2001, o Brasil contou com uma expressiva participação na III Conferência Mundial contra o Racismo, a Discriminação Racial, a Xenofobia e as Formas Conexas de Intolerância, em Durban, na

\footnotetext{
5 Na perspectiva das políticas de governo, destaca-se três momentos cruciais de apresentação da demanda da educação das relações étnico-raciais do movimento negro organizado: i) o Primeiro Congresso Negro Brasileiro, em 1950; ii) a Convenção Nacional do Negro na Constituinte em 1986; iii) a Marcha Zumbi dos Palmares, contra o Racismo pela Cidadania e a Vida, em 1995.
} 
África do Sul. O Plano de Ações aprovado nessa Conferência criou politicamente condições para a proposição de diversas políticas de promoção da igualdade racial.

Assim, em 2003, a Educação das Relações Étnico-Raciais foi transformada em política pública. Contudo, avaliar essa política significa avaliar uma ação que, apesar de possuir demandas antigas, tem um processo recente de implementação.

Considerando o modelo dos ciclos de políticas públicas, analisa-se a implementação da política, uma vez que assume-se que os problemas, os quais essa Política visa combater, já foram identificados, pois entraram na agenda governamental e receberam como resposta uma política curricular a qual possui diversas ações (capacitação dos docentes, apoio a projetos antirracistas nas escolas, revisão dos livros didáticos, estímulo de ações de valorização da cultura negra, inclusão do dia 20 de novembro no calendário escolar, entre outras) e está em fase de implementação.

Kingdom (1995) questiona os modelos de análise de políticas públicas tradicionais, com leis prescritivas como o ciclo das políticas públicas, uma vez que os processos sociais seriam imprevisíveis. Assim, o autor propõe um modelo com três fluxos relativos aos problemas, às soluções e às políticas.

No fluxo dos problemas o cerne da questão envolve a visualização de um problema como necessário ou prioritário para a formulação de uma política pública. Uma vez formulado e apresentado o problema, é iniciada a competição para adentrar a agenda governamental.

Sobre o fluxo das soluções, ou alternativas, é destacada a ausência de uma relação imediata entre o fluxo de problemas e o de soluções, podendo haver a proposição de soluções para problemas que ainda não tenham entrado na agenda, ou problemas que estão sempre na agenda e permanecerem sem solução. Nesse fluxo, são 
analisadas alternativas indicadas à solução dos problemas, as quais passam por um processo de seleção e sofisticação.

Finalmente, no fluxo das políticas, os fatores que determinam a proposição de determinada política seriam conjunturais, dependendo do humor nacional, da composição das forças políticas organizadas e das mudanças internas do governo.

A convergência dos fluxos do problema e a da política geram oportunidades para a entrada da questão na agenda política, enquanto o fluxo das soluções é relevante para que a agenda governamental se articule com a decisória, mas de modo geral, não há uma regra que determine relações de causalidade entre os fluxos, dependendo da aleatoriedade.

No caso da educação das relações étnico-raciais, o fluxo dos problemas seria objetivo de uma análise que remonta às demandas históricas de entidades do movimento negro organizadas, das relações raciais no País e a questão educacional. Esse problema esteve em evidência em diversos momentos históricos, indicando a necessidade de uma análise ao mesmo tempo holística e pormenorizada de existência de uma relação desse processo com o da política.

As soluções propostas, como a revisão do material didático, a formação de docentes, e, até mesmo, a proposta de obrigatoriedade do ensino da história e cultura africana e afro-brasileira foram resultado de inúmeras demandas dessa militância negra e da grande produção intelectual e acadêmica. Assim, a política seria resultado da luta desses movimentos e da relação dessa militância com o parlamento, com o MEC, com os governos estaduais, distrital e federal.

A partir desses dois modelos analíticos, o do ciclo da política e o dos fluxos, será feita a análise da formação de docentes para a educação das relações étnico-raciais. O ciclo das políticas públicas é útil na definição da implementação como etapa do processo de construção da política, resultado de um conjunto de etapas 
anteriores. O modelo dos fluxos de Kingdom (1995) é importante para problematizar esse ciclo, pois a realidade muitas vezes não há uma relação imediata e lógica entre a ordem das etapas, e no caso da educação das relações étnico-raciais há um processo extremamente complexo e randômico de construção da política, no qual não é sequer possível identificar algumas etapas do ciclo.

Desse modo, a fim de alcançar o objetivo dessa pesquisa, que é o de avaliar a formação de docentes na implementação da Política de Educação das Relações Étnico-raciais estabelecida a partir da Lei 10.639/2003 com ênfase na formação de docentes, por meio da análise dos Programas Africanidades e Uniafro, do MEC, foram definidos três objetivos específicos: i) descrever a Política de Promoção da Igualdade Racial, destacando a educação das relações étnico-raciais como um de seus elementos; ii) indicar o estado da implementação da educação das relações étnico-raciais por meio de pesquisas e consultas realizadas pelo MEC e pela Secretaria de Políticas de Promoção da Igualdade Racial (SEPPIR); iii) analisar o processo de implementação da formação de docentes na educação das relações étnico-raciais por meio dos Programas Africanidades e Uniafro do MEC.

Assim, no Capítulo 1, Políticas Raciais: a igualdade possível, são descritas e organizadas as políticas de promoção da igualdade racial a partir do conceito de Jaccoud e Beghin (2002), destacando o processo de inclusão dessa política na agenda decisória governamental como uma conquista da militância negra organizada.

No Capítulo 2, Educação das Relações Étnico-Raciais (S)em Perspectiva, é apresentado o histórico de aprovação da Lei 10.639/2003. Nessa seção são analisadas duas pesquisas independentes realizadas por intelectuais que traçam um panorama da educação das relações étnico-raciais na Educação Básica, são elas "Práticas Pedagógicas de Trabalho com Relações Étnico-Raciais na 
Escola na Perspectiva da Lei 10.639/2003”, realizada em 2012; e "Raça e Classe na Gestão da Educação Básica Brasileira”, realizada em 2010. Por fim, é analisada a consulta realizada pela SEPPIR às Instituições de Ensino Superior Públicas e Privadas (IES) , sobre a implementação da educação das relações étnico-raciais, sendo que, a partir desse resultado, é construída uma proposta de indicadores de formação de docentes.

No Capítulo 3, Africanidades e Uniafro: experiências inconclusas, são analisados os Programas Africanidades e Uniafro, nos seus aspectos relativos à formação de docentes.

Por fim, resumindo o conjunto das contribuições da pesquisa, a conclusão esboça algumas alternativas para a formação de docentes em educação das relações étnico-raciais. 

Para analisar a situação da população negra nos países da Diáspora Africana, Howard Winant (2001) formulou a teoria racial global. Essa teoria estabelece que a escravidão negra do século XVI ao XIX foi um dos principais fatores para a acumulação de riquezas do início da implantação do sistema capitalista, formando, inclusive, um sistema de significados e representações: a supremacia branca. Assim, a desigualdade inerente ao capitalismo seria tão estruturada pelo racismo como a cultura da sociedade.

No caso específico do Brasil, raça e classe são categorias que se sobrepõem em diversas análises sobre população negra. De modo geral, podemos afirmar que as demandas do reconhecimento da especificidade de ser negro e negra, no Brasil, são intrinsecamente ligadas aos apontamentos socioeconômicos desse pertencimento. Assim, as políticas destinadas à correção de distorções históricas voltadas à população negra, congregam os aspectos culturais e socioeconômicos dessa correção.

As políticas de promoção da igualdade racial conformam um conjunto de ações que objetivam a valorização da população negra em sua dimensão cultural, o combate ao racismo e à discriminação racial e a promoção social e econômica de pessoas negras. Segundo Jaccoud e Beghin (2002), a proposição de políticas específicas ao segmento social "população negra" parte do diagnóstico de que as políticas universais não são capazes de solucionar o problema do racismo e suas consequências. Assim, as autoras categorizam essas políticas em três tipos ${ }^{6}$ : políticas valorizativas, para combater o racismo e o preconceito; políticas repressivas e políticas compensa-

\footnotetext{
6 Destaca-se que esse esforço conceitual não necessariamente representa a concepção do órgão coordenador das políticas de promoção da igualdade racial, ou dos órgãos executores. Em verdade, ainda é possível encontrar a menção a políticas de promoção da igualdade racial em documentos oficiais da SEPPIR como algo que não engloba o combate ao racismo no aspecto repressivo.
} 
tórias, que combatem seus efeitos nas condições de vida da população negra.

As políticas compensatórias seriam semelhantes às ações afirmativas ou políticas de priorização da população negra em determinados programas com vistas à correção das distorções históricas que culminaram por fixar a população negra na base da pirâmide social. Elas combatem os efeitos do racismo nas condições de vida da população, contudo, encontram dificuldade em alcançar todo o viés cultural e subjetivo que sustenta a prática da discriminação racial.

As políticas repressivas visam o combate à discriminação racial na sua expressão mais concreta, como na criminalização do racismo no Código Penal Brasileiro. Esse tipo de política tem o objetivo de reprimir a prática da discriminação, contudo, não necessariamente atacando suas causas.

Já as políticas valorizativas visam o combate ao que sustenta a prática da discriminação racial - o preconceito racial -, ao mesmo tempo em que também objetivam a construção de uma nova perspectiva da visão do País e das relações raciais nele constituídas. Parte-se do pressuposto de que a subordinação racial à qual o País foi submetido impossibilitou a expressão e a visibilidade do que é ser negro no Brasil e do processo de construção da identidade negra. Assim, se por um lado busca-se combater as justificativas para atitudes racistas, por outro, visa-se à construção de uma identidade nacional que efetivamente repudie a prática do racismo, não negando a existência das raças e de um processo histórico de discriminação, mas por meio do reconhecimento do passado e da construção de um futuro equitativo e cidadão para o conjunto da população brasileira.

Para Santos (2010), todas as ações passíveis de serem enquadradas entre as definições de Jaccoud e Beghin (2002) são políticas 
de promoção da igualdade racial. Contudo, o autor indica a necessidade de coadunar ações específicas e universais por considerar que a promoção da igualdade racial não é dissociada da redução da desigualdade universal. Desse modo, indica Santos (2010) que

[...] a definição de políticas de promoção da igualdade racial é abrangente, visto que requer a articulação e interação de várias ações e/ou políticas, tais como ações repressivas, ações valorizativas, ações afirmativas, políticas universais e focalizadas. Isso se deve, entre outros fatores, porque, de um lado, o racismo é dinâmico, se renova e se reestrutura de acordo com a evolução da sociedade e das conjunturas históricas e, de outro lado, a luta contra o racismo também não é estática e, desse modo, as formas de reação e combate a ele são múltiplas, requerendo não apenas uma, mas várias ações e políticas públicas e/ou privadas. (MUNANGA, 1994, p. 178 apud SANTOS, 2010).

Outra questão relevante para Santos (2010) é que, a partir de 2003, com a ampliação do escopo de políticas de promoção da igualdade racial, e de 2004, com a política de cotas para negros em diversas IES, há uma maior divulgação das ações afirmativas como exemplo de políticas de promoção da igualdade racial, sendo em muitos casos consideradas sinônimos. Para o autor, essa acepção reduz a capacidade explicativa das políticas de promoção da igualdade racial, sendo necessário classificar claramente as ações afirmativas como políticas de promoção da igualdade racial compensatórias.

Entretanto, cabe reiterar que o processo de organização e efetivação das políticas de igualdade racial é extremamente recente, tendo vários marcos históricos, principalmente em 2003, com a criação da SEPPIR, a regulamentação do processo de titularidade das terras quilombolas e a própria obrigatoriedade do ensino da história africana e afro-brasileira. 
Este capítulo tem como objetivo apresentar um breve panorama das políticas de promoção da igualdade racial, destacando a educação das relações étnico-raciais como elemento de um conjunto de ações com características comuns, como: um histórico recente de institucionalização, uma forte relação com a agenda dos movimentos negros, e um processo de implementação que congrega mais de um órgão da administração pública. Para realizar esse panorama, a princípio é apresentado o surgimento dessas demandas na agenda governamental por meio do destaque de algumas atuações de instâncias da militância negra que as pautaram.

Em seguida, são apresentados os programas e ações relacionados à temática, organizados a partir do conceito de políticas de promoção da igualdade racial de Jaccoud e Beghin (2002). Para realizar tal levantamento foi considerado o relatório de Gestão da SEPPIR, de 2011, os Plano Plurianual (PPA) de 2004-2007, 2008-2011 e 2012-2015, e o Catálogo de Programas do Governo Federal do Ministério do Planejamento, de 2008.

É importante destacar que a partir do PPA 2004-2008 aparece uma nova categoria de programa que tem a população negra como público-alvo, com ou sem focalizaçãoำ É possível classificar as políticas de promoção da igualdade racial como específicas, voltadas especificamente à população negra ou a preservação cultural afro-brasileira, e transversais, os programas que mencionam a população negra e/ou quilombola como um dos públicos-alvo.

\subsection{A institucionalização da luta antirracista}

As políticas de promoção da igualdade racial tem uma estreita relação com as demandas das entidades do movimento negro.

\footnotetext{
7 É possível observar esse tipo de programa nos PPAs 2004-2007, 2008-2011 e 2012-2015.
} 
A luta pela promoção de melhores condições de vida para a população negra é paralela à chegada no Brasil dos primeiros africanos escravizados.

Contudo, a organização das demandas dessa população dentro de um movimento organizado num contexto republicano no País tem seu ponto de inflexão a partir da década de 1930, com a formação da Frente Negra Brasileira (BARBOSA, 1998). Constituída como movimento social em São Paulo, com vista à valorização das pessoas negras, a Frente chegou a se tornar um partido político em 1936, demandando ações como a inclusão de pessoas negras na guarda nacional no Governo Getúlio Vargas. Contudo, com o governo ditatorial de 1937, houve a extinção desse partido político.

A despeito de sua curta existência como partido, a Frente tornou-se uma referência de organização do movimento negro, sendo que, a partir de sua extinção, diversas entidades se formaram e se organizaram a fim de demandar do poder público medidas de combate à discriminação racial. Na década de 1940, a União dos Homens de Cor formada no Rio Grande do Sul se tornou um movimento de expressão nacional. E em São Paulo foi formado o Teatro Experimental do Negro (TEN), uma organização coordenada por Abdias do Nascimento, que viria a ser um dos principais expoentes e representantes da militância negra do País.

O TEN foi uma experiência revolucionária a partir da percepção de que na esfera artística e cultural havia também a exclusão dos atores negros, sendo necessária a constituição de uma companhia teatral toda formada por negros para possibilitar que esses atores tivessem papéis de destaque no teatro. $\mathrm{E}$ ao longo do tempo, o TEN se constituiu num movimento social amplo, realizando atividades de formação e alfabetização de pessoas negras, tendo em vista o baixo acesso à alfabetização, na década de 1940 . 
Em 1950, foi realizado o $1^{\circ}$ Congresso do Negro Brasileiro, em São Paulo. Entre as questões ali discutidas, destacaram-se a valorização da cultura negra e africana, a educação para pessoas negras, a promoção de debates culturais e científicos sobre a questão racial, a inclusão de pessoas negras em cargos públicos e a luta por meios de combate à discriminação racial.

Naquele mesmo ano, em turnê pelo Brasil, a dançarina afro-americana Katherine Dunham é proibida de entrar no Hotel Esplanada, em São Paulo. Até as décadas de 1940 e 1950 era comum que negros não pudessem frequentar determinados ambientes, não pela proibição legal, mas como prática social estabelecida. Contudo, a repercussão do caso de Katherine Dunham é considerada um fator de pressão da opinião pública contra a discriminação racial (DEGLER, 1976). Então, oportunamente, em 1951 foi promulgada a Lei n. 1.390, de 3 de julho de 1951, conhecida como Lei Afonso Arinos, que incluiu entre as contravenções penais a prática de atos resultantes de preconceitos de raça ou de cor.

A partir da segunda metade da década de 1970, há um processo de reorganização dos movimentos negros, fragmentados no período de ferro da ditadura militar. Em 1978, é fundado o Movimento Negro Unificado (MNU), com o nome autoexplicativo para convergir as demandas de diversas entidades negras de todo o País em uma pauta única extensa, tornando-se a referência nacional para representar a demanda do segmento social "população negra" como sociedade civil organizada (DOMINGUES, 2007).

Em 1985 a Lei n. 7.437, de 20 de dezembro de 1985, inclui, novamente, entre as contravenções o preconceito de raça e de cor, entre outros.

Em 1986, é organizada pelo MNU a Convenção Nacional do Negro na Constituinte, realizada nos dias 26 e 27 de agosto de 1986, em Brasília, DF. A partir dessa Convenção, foi elaborado um 
documento para a Assembleia Nacional Constituinte solicitando que a constituição garantisse os seguintes itens: obrigatoriedade do ensino de história da África e da história afro-brasileira; a descriminalização do aborto; a criação de um tribunal especial para julgamento dos crimes de discriminação racial; que a tortura física e/ou psicológica fosse considerada crime contra a humanidade; a criminalização do preconceito racial como crime inafiançável imprescritível, com pena de reclusão; a proibição de programas de controle de natalidade; a proibição do encarceramento de menores; a assistência social à família dos menores infratores; o combate à intolerância religiosa; a titularidade das terras quilombolas; a ruptura de relações diplomáticas e comerciais com países com práticas discriminatórias institucionalizadas.

A Constituição Federal é um grande marco no que tange à garantia de direitos e ao combate ao racismo como política de Estado no Brasil (JACCOUD, 2009a). No texto constitucional foram destacados temas, como a discriminação racial, a diversidade cultural e o reconhecimento dos direitos da população quilombola. Ainda que não tratasse especificamente da promoção da igualdade racial, questões transversais à promoção da igualdade racial e ao combate ao racismo foram desenvolvidas nos artigos: $1^{\circ}$ Dignidade da pessoa humana; $3^{\circ}$ Redução das desigualdades e recusa a qualquer preconceito ou discriminação; $4^{\circ}$ Prevalência dos direitos humanos; $5^{\circ}$ (inciso XLII) Repúdio ao racismo e caracterização como crime inafiançável e imprescritível; 70 (inciso XXX) proibição de diferença de salários, de exercício de funções e de critério de admissão por motivo de sexo, idade, cor ou estado civil.

Jaccoud (2009a) destaca que o sentido de igualdade na Constituição Federal não está restrito à defesa da liberdade, mas à ampliação dos direitos que permitam o exercício da liberdade, ressaltando que a defesa dos direitos difusos ou coletivos de grupos 
sociais específicos permite ao Ministério Público Federal a proposição de ações judiciais em prol das minorias.

No mesmo ano de aprovação da Constituição Federal, foi criada a Fundação Cultural Palmares, por meio da Lei 7.668, de 22 de agosto de 1988, a fim de realizar ações de promoção e preservação da cultura negra brasileira.

Em 1989, a Lei 7.437/1985 foi alterada pela Lei n. 7.716, de 5 de janeiro de 1989, conhecida como Lei Caó, atualmente em vigor, a qual define os crimes resultantes de preconceito de raça ou de cor.

No final da década de 1980 e começo dos anos 1990, são fundados novos grupos de expressão nacional representando a população negra com ênfase na interseção das questões de raça, de gênero, de território, de orientação sexual, de classe, entre outras questões transversais. Dentre esses grupos se destacam as entidades Fundação do Geledés - Instituto da Mulher Negra, em São Paulo, criada em 1988, e a Fundação da Criola, no Rio de Janeiro, fundada em 1992.

Ainda em 1992, a Central Única dos Trabalhadores (CUT) em parceria com o Centro de Estudos das Relações de Trabalho e Desigualdades (CEERT) apresentam à Organização Internacional do Trabalho (OIT) uma representação contra o governo brasileiro por descumprimento de acordo da Convenção n. 111 da OIT, sobre a Discriminação em matéria de Emprego e Profissão da qual o País é signatário.

Em novembro de 1995, foi realizado o I Encontro Nacional de Comunidades Negras Rurais Quilombolas. Nesse mesmo mês e ano foi realizada a Marcha Zumbi dos Palmares, contra o Racismo, pela Cidadania e pela Vida. A organização da Marcha entregou a representantes do governo federal um documento contendo demandas da população negra sobre temas, como: democratização da informação, mercado de trabalho, educação, cultura e comunicação, saúde, violência, religião e terra. 
No que tange à educação, as demandas eram por ampliação da oferta da educação pública de qualidade, eliminação da discriminação no ensino e no material didático, qualificação de docentes para trabalhar a diversidade e combater o racismo, programa de combate ao analfabetismo, auxílios financeiros para jovens negros concluírem a educação básica e ações afirmativas para estudantes negros ingressarem em universidades, em cursos técnicos e profissionalizantes.

Em resposta a esse documento, o governo federal criou o GTI composto por oito membros da sociedade civil pertencentes ao movimento negro, oito membros de ministérios governamentais e dois de secretarias, encarregados de propor ações de combate à discriminação racial, promover políticas governamentais antidiscriminatórias e de consolidação da cidadania da população negra e apoiar iniciativas públicas e privadas com a mesma finalidade.

No GTI a questão da saúde da população negra obteve alguns avanços com temas, como a inclusão do quesito cor, da anemia falciforme e da hipertensão nos questionários básicos dos sistemas de saúde. Em 1996, foi realizada uma mesa redonda sobre Saúde da População Negra no Ministério da Saúde discutindo alguns temas do GTI; nesse mesmo ano houve a inclusão do quesito cor nas declarações de nascidos vivos e de óbito, no Sistema de Informação sobre Mortalidade (SIM), e no Sistema de Informação sobre Nascidos Vivos (SINASC) e sujeitos de pesquisa, além da criação de programas e ações nacionais, estaduais e municipais sobre doença falciforme.

Em resposta ao GTI, à representação da CUT e do CEERT, na OIT, o Ministério do Trabalho criou um GT para a eliminação da discriminação no trabalho. Em 1997 foi criado o Programa Brasil, Gênero e Raça para a efetiva implementação da Convenção n. 111 da OIT. Também no âmbito do GTI foi articulado o apoio à participação brasileira da $3^{\text {a }}$ Conferência Mundial de Combate 
ao Racismo, Discriminação Racial, Xenofobia e Intolerância Correlata, em Durban, na África do Sul. Em 1999 foram realizados encontros nacionais para promover essa preparação por parte da sociedade civil e no ano 2000 foi formado o Comitê Impulsor Pró-Conferência.

Paralelamente, o governo federal lançou, em 1996, o Programa Nacional de Direitos Humanos (PNDH), o qual possuía entre seus objetivos o desenvolvimento de ações afirmativas para negros em universidades, escolas técnicas e profissionalizantes e a formulação de políticas compensatórias para a igualdade racial.

Entre os dias 31 de agosto e 8 de setembro de 2001, o Brasil participou expressivamente da Conferência de Durban com 42 delegados, mais de 300 participantes da sociedade civil, sendo a relatora geral da Conferência e militante negra brasileira, Edna Roland. Para diversos autores (SANTOS; MACHADO, 2008; JACCOUD; BEGHIN, 2002; SANTOS, 2005; BRAGA; SILVEIRA, 2007), tal Conferência é um marco nas políticas de promoção da igualdade racial por lançar as bases para uma série de políticas e ações que posteriormente foram adotadas pelo governo brasileiro.

Entre os principais resultados da Conferência são destaques, a solicitação aos países para proteger as vítimas de racismo e todas as formas de discriminação, promover a igualdade racial e criar melhores condições de vida para a população negra, desenvolver políticas públicas para mulheres e jovens negros, assegurar o acesso à educação de qualidade abordando a história e contribuição africana e de seus descendentes, realizar políticas compensatórias e ações afirmativas para as minorias.

Em 2002, o governo brasileiro lançou o $2^{\circ}$ Plano Nacional de Direitos Humanos, e esse plano reconheceu os males e os efeitos ainda vigentes causados pela escravidão, então tratada como crime contra a humanidade. 
No dia 13 de maio de 2002, foi instituído o Programa Nacional de Ações Afirmativas, no âmbito da Administração Pública Federal, pelo Decreto n. 4.228, de 13 de maio de 2002. O objetivo principal das ações afirmativas de tal programa era garantir a presença de pessoas negras, mulheres ou pessoas com deficiência no serviço público por meio de metas percentuais no preenchimento de cargos do Grupo Direção e Assessoramento Superiores (DAS); também deveria ser adequado o critério de pontuação nas licitações promovidas por órgãos da Administração Pública Federal, para beneficiar fornecedores que comprovassem a participação dos titulares do direito das ações afirmativas do programa, e estabelecimento de metas nas contratações de empresas prestadoras de serviços e de técnicos e consultores no âmbito de projetos desenvolvidos em parceria com organismos internacionais para a participação de pessoas com deficiência, negras ou mulheres. Tal decreto não foi implementado, as metas nunca foram instituídas e o Comitê de Avaliação e Acompanhamento do Programa Nacional de Ações Afirmativas não é ativo.

A partir de 2003, a questão racial ganha grande destaque na agenda governamental. Nesse ano foi criada a SEPPIR, o Conselho Nacional de Promoção da Igualdade Racial (CNPIR), foi aprovada a Lei 10.639/2003, e promulgado o Decreto 4.887, de 20 de dezembro de 2003, que regulamenta a titularidade das terras quilombolas.

Em 2005, ocorreu a $1^{\text {a }}$ Conferência Nacional de Promoção da Igualdade Racial (CONAPIR). Em 2009, são aprovados o Plano Nacional de Promoção da Igualdade Racial (PLANAPIR) e o Plano de Implementação da Lei 10.639/2003. Em 2010, é aprovado o Estatuto da Igualdade Racial.

No ano de 2012, é declarada pelo Supremo Tribunal Federal a constitucionalidade da reserva de vagas para negros nas instituições federais de ensino superior. Nesse mesmo ano, é aprovada a 
Lei n. 12.711, de 29 de agosto de 2012, que dispõe sobre o ingresso nas universidades federais e nas instituições federais de ensino técnico de nível médio, estabelecendo a reserva de 50\% das vagas dessas instituições a estudantes da rede pública de ensino com renda familiar per capita até 1,5 salário mínimo, e, dentro desse percentual as cotas raciais.

Diversas autoras (RIOS, 2012; LIMA, 2010; JACCOUD, 2009a) destacam esse período como de grande emergência da questão racial na agenda governamental. Contudo, observam também a continuidade das ações que foram iniciadas em 1995 com a Marcha Zumbi dos Palmares e o GTI.

Assim, ainda que a militância negra seja um movimento constante e ininterrupto na história do Brasil, considera-se relevante o destaque de três momentos: i) 1950, o $1^{\circ}$ Congresso do Negro Brasileiro; ii) 1986, a Convenção Nacional do Negro pela Constituinte; iii) 1995, a Marcha Zumbi dos Palmares contra o Racismo, pela Cidadania e a Vida, pois nesses três momentos, a militância consegue impor sua pauta na agenda governamental.

Indica-se também a necessidade de pontuar que não necessariamente a pauta dos movimentos negros é incorporada integralmente pelas ações governamentais que são formuladas para supostamente responder a essas demandas. Em casos específicos, como na aprovação do Estatuto da Igualdade Racial, explicitada no tópico seguinte, é possível observar uma grande disparidade entre as políticas demandadas e as efetivamente aprovadas.

Por fim, esse histórico tem como papel mostrar que as políticas de promoção da igualdade racial são fruto das demandas de instituições organizadas da militância negra. Tais políticas podem ser vistas como uma tentativa de aprofundamento no tratamento de questões que já estavam na pauta havia mais de meio século. 


\subsection{Promoção da igualdade racial: as ações e omissões}

A Política Nacional de Promoção da Igualdade Racial foi legalmente instituída pelo Decreto n. 4.886, de 20 de novembro de 2003; esse decreto reconhece a discriminação racial como estruturante para a organização social do País e recupera avanços então recentes sobre o tema, como a criação da SEPPIR e a Conferência de Durban.

O objetivo da Política Nacional de Promoção da Igualdade Racial é definido como a redução das desigualdades raciais no País, com ênfase à população negra. Estabelece-se a SEPPIR como coordenadora da política, sendo a sua execução atribuída a órgãos da administração pública direta. Os custos financeiros para a implementação da política fazem parte das despesas dos órgãos executores.

As ações que congregam o que vem a ser a promoção da igualdade racial estão presentes no anexo I do decreto, são elas:

- Implementação de modelo de gestão da política de promoção da igualdade racial, que compreenda conjunto de ações relativas à qualificação de servidores e gestores públicos, representantes de órgãos estaduais e municipais e de lideranças da sociedade civil.

- Criação de rede de promoção da igualdade racial envolvendo diferentes entes federativos e organizações de defesa de direitos.

- Fortalecimento institucional da promoção da igualdade racial.

- Criação do Sistema Nacional de Promoção da Igualdade Racial.

- Aperfeiçoamento dos marcos legais.

- Apoio às comunidades remanescentes de quilombos.

- Incentivo ao protagonismo da juventude quilombola.

- Apoio aos projetos de etnodesenvolvimento das comunidades quilombolas. 
- Desenvolvimento institucional em comunidades remanescentes de quilombos.

- Apoio sociocultural a crianças e adolescentes quilombolas.

- Incentivo à adoção de políticas de cotas nas universidades e no mercado de trabalho.

- Incentivo à formação de mulheres jovens negras para atuação no setor de serviços.

- Incentivo à adoção de programas de diversidade racial nas empresas.

- Apoio aos projetos de saúde da população negra.

- Capacitação de professores para atuar na promoção da igualdade racial.

- Implementação da política de transversalidade nos programas de governo.

- Ênfase à população negra nos programas de desenvolvimento regional.

- Ênfase à população negra nos programas de urbanização e moradia.

- Incentivo à capacitação e créditos especiais para apoio ao empreendedor negro.

- Celebração de acordos de cooperação no âmbito da Alca e Mercosul.

- Incentivo à participação do Brasil nos fóruns internacionais de defesa dos direitos humanos.

- Celebração de acordos bilaterais com o Caribe, países africanos e outros de alto contingente populacional de afro-descendentes.

- Realização de censo dos servidores públicos negros.

- Identificação do IDH da população negra.

- Construção do mapa da cidadania da população negra no Brasil. 
O Decreto 4.886/2003 não estabelece quais são os programas relacionados com essa política, ele tão somente traça linhas gerais de ações. Algumas ações mencionadas no decreto já estavam em execução por políticas anteriores como o "apoio" às comunidades quilombolas, outras ações jamais se realizariam, como algum acordo de cooperação no âmbito da Área de Livre Comércio das Américas (ALCA), haja vista que a ALCA não se efetivou na América. Sob o ponto de vista do tipo de ação há também uma considerável discrepância, algumas são ações práticas como a "[...] capacitação de professores para atuar na promoção da igualdade racial" e outras são linhas gerais desfocadas, como a "implementação da política de transversalidade nos programas de governo." (BRASIL, 2003).

Assim, pode-se dizer que esse Decreto não dispõe sobre a organização da administração pública para efetivar uma política governamental, mas lança uma intenção de organizar e classificar as políticas que já existiam e que viriam a seguir sob essa perspectiva.

Além disso, é mister destacar que o conceito de políticas de promoção da igualdade racial de Jaccoud e Beghin (2002) usado nesta pesquisa, não é necessariamente o mesmo conceito usado pelas políticas de promoção da igualdade racial implantadas na SEPPIR.

Ainda que a criação da SEPPIR seja uma resposta a uma demanda histórica dos movimentos negros, o uso de termos como "promoção da igualdade racial" ao invés de "combate ao racismo e suas consequências", e "racial com ênfase na população negra" são complexos. Ora, o racial da SEPPIR é mais negro e afro-brasileiro do que qualquer outra possível raça existente no País. Com exceção das ações voltadas a ciganos abrigadas na SEPPIR, ou pontuais ações voltadas aos povos indígenas, não é possível afirmar que haja outra raça que não a negra e suas interseções com a cultura, a 
religiosidade, a tradição de matriz africana, a territorialidade, entre outros fatores, como alvo dessas políticas.

Porém, essa escolha - de certa camuflagem - para os objetivos iniciais da SEPPIR, destacando a promoção da igualdade em detrimento das dimensões valorizativas, repressivas e até do enfrentamento ao racismo em seu título, tem impacto nos objetivos da Política Nacional de Promoção da Igualdade Racial, na medida em que esses objetivos dialogam mais com as políticas compensatórias, mesmo nas ações voltadas às comunidades quilombolas, do que com os aspectos valorizativos e repressivos.

Em 2003, foi instituído o Fórum Intergovernamental de Promoção da Igualdade Racial (FIPIR), com o objetivo de promover a incorporação da igualdade racial no âmbito federal, estadual e do Distrito Federal e municipal. ${ }^{8}$

\footnotetext{
8 Atualmente, os organismos de promoção da igualdade racial nos estados são: Secretaria de Estado e Justiça e Direitos Humanos do Acre; a Secretaria da Mulher, da Cidadania e Direitos Humanos de Alagoas, que possui uma Superintendência de Promoção de Cidadania e Direitos Humanos/Gerência Afro-Quilombola; a Secretaria de Estado de Justiça e Direitos Humanos do Amazonas; a Secretaria Extraordinária de Políticas para Afrodescendentes do Amapá, a Secretaria da Promoção da Igualdade Racial (SEPROMI) da Bahia; a Coordenadoria Especial de Políticas Públicas para a Promoção da Igualdade Racial do Ceará; a Secretaria de Estado da Igualdade Racial do Distrito Federal, a Secretaria de Estado de Políticas para Mulheres e Promoção da Igualdade Racial (SEMIRA) de Goiás; a Secretaria de Estado da Igualdade Racial do Maranhão; a Coordenadoria Especial de Políticas Pró Igualdade Racial de Minas Gerais; a Coordenadoria de Políticas para a Promoção da Igualdade Racial do Mato Grosso do Sul; o Conselho Estadual de Promoção da Igualdade Racial de Mato Grosso; a Assessoria de Promoção da Igualdade Racial do Estado do Paraná; Gerência de Equidade Racial - Secretaria de Estado da Mulher e da Diversidade Humana da Paraíba; Assessoria de Igualdade Racial e Comitê Estadual de Promoção Étnico Racial de Pernambuco; Gerencia de Igualdade Racial - Diretoria de Direitos Humanos do Piauí; Secretaria de Estado de Assistência Social e Direitos Humanos/Superintendência de Igualdade Racial do Rio de Janeiro; Coordenadoria de Políticas de Promoção da Igualdade Racial (COEPIR); Secretaria de Estado da Justiça e
} 
O Decreto n. 6.872, de 4 de junho de 2009, institui o PLANAPIR, resultado de propostas da I Conferência Nacional de Promoção da Igualdade Racial e do GTI instituído pelo Decreto n. 8, de novembro de 2005.

O PLANAPIR possui ações divididas nas seguintes linhas de ação: Eixo 1: Trabalho e Desenvolvimento Econômico; Eixo 2: Educação; Eixo 3: Saúde; Eixo 4: Diversidade Cultural; Eixo 5: Direitos Humanos e Segurança Pública; Eixo 6: Comunidades Remanescentes de Quilombos; Eixo 7: Povos Indígenas; Eixo 8: Comunidades Tradicionais de Terreiro; Eixo 9: Política Internacional; Eixo 10: Desenvolvimento Social e Segurança Alimentar; Eixo 11: Infraestrutura e Eixo 12: Juventude. De modo geral, as ações indicadas em cada eixo variam das mais gerais possíveis, como "Combater os estigmas contra negros, índios e ciganos" (Eixo 5, Ação VII), às mais específicas, como "Propor sistema de incentivo fiscal para empresas que promovam a igualdade racial” (Eixo 1, Ação VIII) (BRASIL, 2009). E, de modo específico, é possível afirmar que o acompanhamento e monitoramento do plano não se encontram representados no Relatório de Gestão de SEPPIR 2011, tão pouco o Comitê de Articulação e Monitoramento do PLANAPIR, criado pelo mesmo decreto que institui o Plano, está em atividade.

Em 2010, foi promulgada a Lei n. 12.288, de 20 de julho de 2010, que institui o Estatuto da Igualdade Racial. O Estatuto é

Cidadania do Rio Grande do Norte; Núcleo de Igualdade Racial - Secretaria de Estado de Assistência Social de Rondônia; Núcleo de Igualdade Racial - Secretaria de Estado da Justiça e da Cidadania - Departamento de Justiça, Direitos Humanos e Cidadania de Roraima; Coordenadoria da Igualdade Racial - Secretaria de Justiça e Desenvolvimento Social do Rio Grande do Sul; Coordenadoria de Estado da Igualdade Racial de Santa Catarina; Secretaria de Estado do Trabalho da Juventude e da Igualdade Social - Coordenadoria de Políticas para a Promoção da Igualdade Racial de Sergipe; Secretaria da Justiça e da Defesa da Cidadania - Coordenação de Políticas para a População Negra e Indígena de São Paulo. 
propagado pela SEPPIR como um “[...] importante instrumento para que as desigualdades raciais sejam reconhecidas e abordadas em diferentes níveis de governo." (BRASIL, 2010). Esse documento é um dos referenciais legislativos para a atual organização das políticas de promoção da igualdade racial. Faz-se necessário, antes da apresentação de seus principais elementos, realizar um breve resumo do seu processo de aprovação, o qual durou mais de 10 anos, para indicar o que se pretendia com tal legislação e o que efetivamente foi alcançado.

O documento original previa ações afirmativas nos serviços públicos e privados com indicação de percentuais mínimos para a reserva de vagas nesses e também nos partidos políticos, filmes, propagandas e peças publicitárias, além da especificação de procedimentos de titulação e reconhecimento das terras quilombolas, a fim de promover maior eficiência e efetividade nessas ações. Também era proposta a criação de um fundo específico para as políticas e ações aprovadas no âmbito do Estatuto.

Depois de cinco anos tramitando, o projeto de lei foi aprovado no Senado Federal e encaminhado à Câmara dos Deputados. Nessa casa legislativa, houve um processo intenso de desconstrução do Estatuto e esvaziamento do conteúdo transformador de suas propostas (SANTOS; DOS SANTOS; BERTÚLIO, 2011). Foram excluídas as menções aos percentuais de cotas; a questão da titularidade das terras quilombolas teve a supressão de seus principais artigos, e, de modo geral, o documento foi reescrito possuindo um caráter autorizativo, não obrigatório.

Em resposta a esse processo, na $2^{\text {a }}$ Conferência Nacional de Promoção da Igualdade Racial, ocorrida em setembro de 2009, diversas entidades do movimento negro ali representadas divulgaram conjuntamente o "Manifesto em Defesa dos Direitos e da Autonomia da População Negra", o qual defendia o texto original aprovado no Senado Federal em 2005. Assim o documento se opunha: 
Ao caráter autorizativo e não determinativo desta proposta de Estatuto, que delega aos gestores a decisão de cumprir ou não o que está escrito.

À eliminação do instrumento das cotas e a restrição das políticas de ação afirmativa apenas à parcela da população negra brasileira abaixo da linha da pobreza.

O não reconhecimento dos territórios tradicionais quilombolas - terras ocupadas por remanescentes de quilombos, utilizadas para a garantia de sua reprodução física, social, econômica e cultural, bem como as áreas detentoras de recursos ambientais necessários para a subsistência das comunidades, para a preservação da sua cultura, englobando os espaços de moradia, espaços sagrados e sítios históricos. A retirada da criação do fundo de recursos financeiros para a implementação de políticas públicas para a população negra. (MANIFESTO em defesa..., 2009).

A SEPPIR, dialogando com o teor do manifesto dos movimentos sociais, publicou a Nota de Esclarecimento - Estatuto da Igualdade Racial, de 3 de setembro de 2009, defendendo a versão da Câmara dos Deputados, sugerindo que as alterações no documento contemplam as propostas que havia anteriormente. Segundo a Nota da SEPPIR:

Do texto substitutivo:

A atual disposição dos artigos no substitutivo ao PL n. 6.264/2005 visa melhorar os eixos de atuação do instrumento normativo. Os artigos que tratavam de assuntos específicos inseridos em outros capítulos foram remanejados para a área pertinente, havendo apenas adequação estrutural, sem ferir o sentido original do projeto.

Das cotas:

O Projeto de Lei n. ${ }^{\circ} 6.264$ de 2005 prevê nos artigos 18, 19 e 20 a adoção de programas que assegurem a ocupação de vagas nos cursos oferecidos pelas instituições públicas 
federais, garantindo a inserção dos estudantes negros nas instituições públicas de ensino médio e superior.

Das políticas de ações afirmativas:

Desde o Projeto de Lei original constam indicativos de prioridade de atendimento às pessoas auto declaradas de cor preta/parda que se situem abaixo da linha de pobreza: "Art. 34. Entre os beneficiários das iniciativas de promoção da igualdade racial terão prioridade os que sejam identificados como pretos, negros ou pardos no registro de nascimento e que, de acordo com os critérios que presidem a formulação do índice de Desenvolvimento Humano do Programa das Nações Unidas para o Desenvolvimento, se situem abaixo da linha de pobreza."

O Substitutivo, publicado em 2008, reestruturou o artigo mantendo a premissa apontada segundo os índices do IBGE. Contudo, o Estatuto da Igualdade Racial contempla toda a população negra, garantindo condições de igualdade e oportunidade, econômica, social, política e cultural. Do direito dos remanescentes das Comunidades dos Quilombos às suas terras:

O PL no 6.264/2005 reafirma e resguarda o direito dos remanescentes dos quilombos as suas terras, na forma que dispõe o artigo 68 do Ato das Disposições Transitórias da Constituição Federal. Os procedimentos garantidores da regularização fundiária das áreas de remanescentes de quilombolas estão inscritos no Decreto n. ${ }^{\circ} 4.887$ de 2003, que é o instrumento legal específico à regulamentação da fruição do direito constitucional em relação às terras quilombolas. Financiamento das políticas públicas:

A supressão do fundo de financiamento deu-se após intenso debate com os demais órgãos do Governo, ficando assegurada a transversalidade das políticas públicas de igualdade racial. Ou seja, não apenas um ministério, mas todos os órgãos do Governo assumem a responsabilidade pela implementação de políticas afirmativas, com destinação de recursos próprios. Desta forma, haverá destinação crescente de recursos para implementação de políticas de inclusão dos segmentos alcançados pelo Estatuto. (SEPPIR, 2009). 
De modo bem imediato, é impossível afirmar que não estabelecer um percentual mínimo de cotas em ações afirmativas seja equivalente a mencionar a possibilidade de adoção de ações afirmativas pelo Estado brasileiro.

No que tange à regularidade das terras quilombolas, é importante indicar que, de fato, quando o Estatuto foi elaborado, o Decreto n. 4.887, de 20 de novembro de 2003, que regulamenta o processo de titularidade das terras quilombolas, não existia. Porém, frisa-se que em 2009, quando a movimentação para a aprovação do Estatuto estava já bastante acelerada, havia desde aquele momento a constatação por parte dos movimentos sociais de que esse processo de regularidade seria insuficiente para a resolução dos diversos problemas das comunidades, além de constituir um problema em si mesmo, em virtude da morosidade do processo.

E no que tange ao financiamento, é no mínimo equivocada a afirmação de que a não constituição de um fundo específico não seja uma derrota sob o ponto de vista do financiamento das políticas. Ainda que a SEPPIR tenha um caráter mais articulador e transversal do que executor, um fundo próprio com especificação da origem dos recursos garantiria a continuidade das ações sob-responsabilidade específica da Secretaria, além de propiciar o cofinanciamento das ações nos entes federados, uma vez instituído o Sistema Nacional de Promoção da Igualdade Racial (SINAPIR), previsto no Estatuto.

Assim, mantendo as exclusões propostas pela Câmara dos Deputados, o Estatuto da Igualdade Racial foi instituído. Nas Disposições Preliminares estão definidas discriminação racial, desigualdade racial, desigualdade de gênero e raça, população negra, políticas públicas, ações afirmativas, e reiterados direitos à igualdade e diversidade já garantidos na Constituição Federal.

No Título II, são definidos os Direitos Fundamentais: Direito à Saúde (Capítulo I), Direito à Educação, Cultura, ao Esporte 
e ao Lazer (Capítulo II), Direito à Liberdade de Consciência, de Crença e ao Livre Exercício dos Cultos Religiosos (Capítulo III), Acesso à Terra e à Moradia (Capítulo IV), Do Trabalho (Capítulo V), Dos Meios de Comunicação (Capítulo VI). No Título III, é instituído SINAPIR a fim de articular todas as políticas de promoção da igualdade racial no âmbito federal e dos estados e municípios.

A constituição do SINAPIR é a maior novidade trazida pelo Estatuto da Igualdade Racial, haja vista que as garantias previstas no Título II, dos Direitos Fundamentais, já eram asseguradas pela legislação vigente. Contudo, tal sistema carece de instrumentos de implementação, ainda não definidos.

Durante os meses de março e abril de 2013, foram disponibilizados para consulta e apresentação de propostas, o projeto básico do SINAPIR por meio do Programa de Governo Eletrônico Brasileiro. $\mathrm{O}$ projeto básico apresentado, que ainda será alterado a partir das contribuições da sociedade, indica a continuidade da Política Nacional de Promoção da Igualdade Racial e do Estatuto da Igualdade Racial, ou seja, uma legislação superficial e genérica.

O projeto de Sistema é dividido em 11 partes: A - Definição e organização do sistema; B - Marcos regulatórios; C - Objetivos do sistema; D - Princípios básicos do sistema; E - Fortalecimento das Políticas de Igualdade Racial com o sistema; F - Ações afirmativas no SINAPIR; G - Instrumentos necessários ao SINAPIR; $\mathrm{H}$ - Coordenação e composição do sistema; I - Estrutura do sistema; J - FIPIR: instituição, objetivos e competências, e K - Formas de gestão e atuação do SINAPIR.

De modo geral, de A a C há uma retomada de tudo o que a legislação anterior prevê. Em D, os princípios organizadores do sistema: descentralização, desconcentração, participação social, são misturados a atividades e estratégias como "[...] a comunicação e negociação entre os órgãos e entidades envolvidos na elaboração e implementação das políticas de igualdade racial”. 
Na parte E, são definidas o papel da SEPPIR, de coordenadora e articuladora, exatamente conforme a legislação que cria a SEPPIR, e do SINAPIR como o sistema que organiza o plano estratégico. Contudo, a forma de realização dessa organização não está definida em nenhuma parte.

Em F, é indicada a necessidade de adoção de ações afirmativas por parte dos órgãos que integram o SINAPIR. No entanto, ações afirmativas são usadas como sinônimos de políticas de promoção da igualdade racial, sendo que é indicado que "[...] as políticas de ação afirmativa podem ser colocadas em prática mediante a adoção de sistema de cotas, sistema de metas, sistema de oferta de bolsas, entre outras medidas, nos termos da legislação vigente.", ou seja, o estatuto não define a forma de adoção e o SINAPIR também não.

Em G são definidos os instrumentos necessários ao SINAPIR que são o PPA, o PLANAPIR e a Rede-SINAPIR, que é a rede a ser criada por meio do sistema para que ele efetivamente funcione. $\mathrm{O}$ documento define que, entre outros itens como o cadastramento dos organismos de promoção da igualdade racial e o lançamento de um site, a Rede deve, para ser lançada, realizar o "[...] aperfeiçoamento e da disseminação dos instrumentos e técnicas de avaliação e monitoramento das ações do SINAPIR e do impacto destas nas condições de vida das populações negra e indígena." (BRASIL, 2013).É importante destacar que: i) a questão indígena ainda permanece pairando entre as ações da SEPPIR de forma totalmente complexa, haja vista que há uma política e um órgão específicos voltados a esse público; ii) a formação da Rede, que em tese é o que faria o plano funcionar, carece ainda da definição de instrumentos e técnicas de monitoramento das ações, que era exatamente o que o SINAPIR deveria propor.

No item $\mathrm{H}$ é dito, novamente, que a SEPPIR coordena o SINAPIR, e é apresentada a composição por, basicamente, todos 
os ministérios com pautas sociais, e os estados e municípios por meio de instrumento de adesão não definido. Em I, é definida a estrutura do Sistema, indicado os organismos integrantes, e na letra $\mathrm{J}$ é re-estruturado o Fórum Intergovernamental de Promoção da Igualdade Racial (FIPIR).

Ao final, na letra $K$, são definidos os modos de gestão do SINAPIR, definindo como requisito mínimo a existência de um conselho de promoção da igualdade racial, sendo considerada a gestão plena referente à existência de um organismo específico de promoção da igualdade racial, a intermediária pela questão racial ser tema de um órgão, ainda que não específico, e a básica quando a questão racial é coordenada por uma institucionalidade sem autonomia financeira.

Por fim, no que tange ao SINAPIR, espera-se que com as contribuições da sociedade ao texto básico, seja mais bem definido como esse Sistema vai ajudar a organizar as políticas de promoção da igualdade racial já em curso, qual o papel dos estados nas políticas implementadas pela SEPPIR e vice-versa, além de quais e como esses instrumentos criados ajudarão efetivamente a aprimorar a implantação dessas políticas. Porém, a falta de objetividade e a generalidade das proposições do texto apresentado para a consulta pela SEPPIR, indicam uma total consonância com as demais legislações relativas à promoção da igualdade racial, sem apresentar novidades do ponto de vista de determinações aos executores da Política de Promoção da Igualdade Racial.

Assim, foram apresentados a Política Nacional de Promoção da Igualdade Racial, o PLANAPIR e o Estatuto da Igualdade Racial, instrumentos organizadores das políticas de promoção da igualdade racial do governo federal, e a proposta do SINAPIR. Os limites e potencialidades desses instrumentos são resultado das pactuações que se efetivaram para a garantia da existência dessa legislação. 


\subsubsection{Políticas compensatórias}

As políticas compensatórias têm um foco na promoção da equidade e equiparação de distorções na igualdade pretendida. Elas se encontram em diversas modalidades: reserva de vagas, priorização de público como destinatário da política, entre outras.

A adoção por parte do Estado brasileiro de práticas de reserva de vagas para a inclusão de grupos específicos e minorias não é recente no País9. Contudo, a menção ao termo "ação afirmativa" para esse tipo de política na legislação somente é iniciado pelo Decreto n. 1.904, de 13 de maio de 1996, que institui o Primeiro Programa Nacional de Direitos Humanos, o qual possuía entre seus objetivos "[...] desenvolver ações afirmativas para o acesso dos negros aos cursos profissionalizantes, à universidade e às áreas de tecnologia de ponta." (BRASIL, 1996).

Em 2001, o Brasil foi um dos países participantes e signatários da $3^{a}$ Conferência Mundial Contra o Racismo, a Discriminação Racial, a Xenofobia e a Intolerância Conexa, em Durban, África do Sul. Entre os resultados da Conferência, destaca-se a solicitação da adoção de ações afirmativas por parte dos países signatários, indicando a necessidade de

9 Lei n. 5.465/1968: previa a adoção de reserva de vagas de 50\% para as escolas de Agronomia e Veterinária para candidatos agricultores ou filhos destes, proprietários de terras ou não, que residissem na zona rural ou em locais que não possuíam estabelecimentos de ensino.

Lei n. 8.112/1990: estabelece reserva de vagas para pessoas com deficiência no serviço público da União.

Lei n. 8.213/1991: dispõe sobre a reserva de vagas para pessoas com deficiência na iniciativa privada;

Lei n. 8.666/1993: estabelece a dispensa de licitação para contratação de instituições filantrópicas de pessoas com deficiência.

Lei n. 9.504/1997: cria reserva da vagas para mulheres nas candidaturas partidárias. 
[...] desenvolver programas destinados aos afrodescendentes alocando recursos adicionais aos serviços de saúde, educação, moradia, energia elétrica, saneamento, medidas de controle ambiental e promover a igualdade de oportunidades no emprego, bem como em outras iniciativas de ações afirmativas ou positivas. (NAÇÕES UNIDAS, 2001).

As ações afirmativas são políticas públicas, ou privadas, compensatórias com vistas à correção das distorções históricas que culminaram por fixar determinados grupos étnicos, sociais ou raciais, como a população negra, em situação de desvantagem social (JACCOUD; BEGHIN, 2002). As ações afirmativas raciais objetivam o combate aos efeitos do racismo nas condições de vida de pessoas negras. Nessa esfera, há ações afirmativas nas áreas de trabalho, saúde, educação e cultural no âmbito federal.

No eixo do trabalho, as ações são acompanhadas das do Ministério do Trabalho no Subcomitê de Promoção da Igualdade Racial e Trabalho Decente, no contexto da Agenda Nacional do Trabalho Decente.

No caso das ações no que tange à saúde, em 2007 foi instituída a Política Nacional de Saúde Integral da População Negra, que visa a atenção às demandas de saúde relativas à população negra, com especial destaque à necessidade da correta identificação do quesito raça/cor como ponto de partida para diagnósticos populacionais; a sensibilizações e capacitações dos profissionais da saúde no trato com pessoas negras; e ao Programa de Anemia Falciforme.

Há coordenações ou comitês de Saúde da População Negra do Âmbito das Secretarias Estaduais de Saúde nos estados de São Paulo, Pernambuco, Rio Grande do Sul, Paraíba e Acre.

O eixo da cultura tem um grande histórico de ações de promoção da igualdade racial, especialmente em políticas valorizativas, 
a serem analisadas ao longo deste capítulo. Contudo, no que tange às políticas compensatórias, são realizadas ações relativas ao incentivo e apoio a produções culturais negras, com reserva de vagas e priorizações.

A adoção de reserva de vagas para estudantes negros em universidades públicas foi iniciada pioneiramente na Universidade Estadual do Bahia (UNEB), que aprovou a reserva de $40 \%$ de suas vagas para estudantes afrodescendentes em 2002 e iniciou a implementação em 2003. Nesse mesmo ano, a Universidade de Brasília (UnB) aprovou a adoção do sistema de cotas para negros no seu vestibular, iniciando essa prática em 2004. Atualmente cerca de 180 IES adotam algum tipo de ação afirmativa, de acordo com a autonomia das universidades estabelecida pela Constituição Federal.

Segundo dados do Grupo de Estudos Multidisciplinar e de Ações Afirmativas da Universidade Estadual do Rio de Janeiro, até 2012, onze estados decretaram leis que instituem programas de ação afirmativa em IES. São eles: Alagoas, Lei n. 6.542, de 7 de dezembro de 2004; Amapá, Leis Estaduais n. 1.022 e n. 1.023, de 30 de junho de 2006 e Lei n. 1.258, de 18 de setembro de 2008; Amazonas, Lei n. 2.894, de 31 de maio de 2004; Goiás, Lei n. 14.832, de 12 de julho de 2004; Maranhão, Lei n. 9.295, de 17 de novembro de 2010; Mato Grosso do Sul, Leis n. 2.605 e n. 2.589, de 2003; Minas Gerais, Lei Estadual n. 15.259, de 27 de julho de 2004 e Lei Estadual n. 13.465, de 12 de janeiro de 2000; Paraná, Lei n. 13.134, de 18 de abril de 2001, da Casa Civil, modificada pela Lei Estadual n. 14.995, de 9 de janeiro de 2006; Rio de Janeiro, Lei Estadual n. 4.151, de 4 de setembro de 2003; Rio Grande do Norte, Lei Estadual n. 8.258, de 27 de dezembro de 2002; Rio Grande do Sul, Lei n. 11.646, de 10 de julho de 2001 (GEMAA, 2012).

No âmbito nacional, a Lei n. 12.711, de 29 de agosto de 2012, instituiu a reserva de vagas para alunos oriundos da rede 
pública nas IES vinculadas ao MEC, sendo que as vagas devem ser preenchidas por autodeclarados pretos, pardos e indígenas, em proporção no mínimo igual ao percentual dessa população conforme definido no último Censo, do Instituto Brasileiro de Geografia e Estatística (IBGE).

No que tange à adoção de reserva de vagas no serviço público, o estado do Paraná estabeleceu, pela Lei n. 14.274, de 24 de dezembro de 2003, cotas de $10 \%$ para afrodescendentes nos cargos públicos do estado e o Mato Grosso do Sul estabeleceu, pelas Leis n. 3.594, de 10 de dezembro de 2008 e n. 3.994, de 12 de julho de 2010, a reserva de vagas em concursos públicos para pessoas negras (10\%) e indígenas (3\%). Os municípios que também têm estabelecido reserva de vagas para pessoas negras em leis específicas são: o Rio de Janeiro, RJ, por meio da Lei n. 4.978, de 9 de dezembro de 2008 , que estabelece a reserva de $25 \%$ de vagas para afrodescendentes dos respectivos gêneros, sendo $10 \%$ das vagas reservadas para homens e $10 \%$ para mulheres nos concursos públicos municipais; Viamão, RS, a Lei n. 3.211, de 29 de março de 2004 estabelece cotas de $44 \%$ para afro-brasileiros em cargos de confiança da administração pública municipal, e Campinas, SP, a Lei n. 12.156, de 13 de dezembro de 2004 estabelece a reserva de 30\% dos cargos comissionados do executivo a afrodescendentes.

No âmbito federal, atualmente há uma discussão em curso no Ministério do Planejamento, Orçamento e Gestão (MPOG), sobre a adoção de reserva de vagas para pessoas negras em concursos públicos federais, porém ainda não há nenhum resultado desse processo.

\subsubsection{Políticas repressivas}

As políticas repressivas à prática do racismo são as que possuem o histórico mais antigo entre as demais de promoção da 
igualdade racial, em virtude da criação da Lei Afonso Arinos, no último governo de Getúlio Vargas. Essa lei estabeleceu multas a estabelecimentos que se recusassem a receber, atender ou empregar pessoas negras, e também punição para clubes recreativos e estabelecimentos de lazer que se recusassem a permitir a entrada de pessoas negras, e também para instituições de ensino que obstassem a matrícula de pessoas por preconceito de raça ou cor.

A lei inclusive instituía a possibilidade de o servidor público que obstasse a contratação de outrem em razão de preconceito ser demitido. Assim como era indicada a possibilidade de suspensão do funcionamento de estabelecimentos particulares em virtude da reincidência nesse tipo de contravenção.

A Lei n. 7.743, de 28 de junho de 1989, conhecida como Lei Caó, é uma atualização da Lei Afonso Arinos nos seguintes aspectos: i) indica a contravenção na prática de atos resultantes de preconceito de raça ou cor, sexo ou estado civil, assim pretende-se combater a prática de racismo, sexismo e misoginia; ii) há a possibilidade de prisão de três meses a um ano acompanhada de multa nas mesmas situações indicadas pela Lei Afonso Arinos.

No que tange o aspecto da criminalização do racismo, o texto constitucional representou um grande avanço. $\mathrm{O}$ repúdio ao racismo é princípio constitucional que rege as relações internacionais estabelecidas pelo País. No artigo 5\%, inciso XLII, há a classificação do racismo como "[...] crime inafiançável e imprescritível, sujeito à pena de reclusão.” (BRASIL, 1979).

Contudo, esse crime tem uma elevada impunidade, tanto pela naturalização da discriminação racial no cotidiano de pessoas negras, quanto pelo racismo institucional arraigado no Sistema de Justiça. Dados do Relatório Anual das Desigualdades Raciais no Brasil 2009-2010, realizado pelo Laboratório de Análises Econômicas, Sociais e Estatísticas das Relações Raciais (LAESER), da 
Universidade Federal do Rio de Janeiro (UFRJ), baseados em julgamentos de Tribunais de Justiça estaduais e do Distrito Federal e dos Territórios mostram que no período de 2007 a 2008 somente 148 casos de discriminação racial foram julgados, sendo que, desses, $66,9 \%$ dos réus foram vitoriosos, contra $29,7 \%$ de vitória das vítimas.

De modo geral, essa é uma linha de complexo acompanhamento. Para a efetividade da punição do racismo, é necessária a consolidação de uma rede de atendimento que vai do acolhimento e efetivo registro da denúncia na delegacia, à apuração do inquérito, julgamento do mérito pelo tribunal até a efetiva condenação e punição dos responsáveis.

Nesse aspecto, diversas iniciativas têm sido realizadas, especialmente pelos movimentos sociais, tanto para a conscientização da população de que racismo é um crime e o devido registro e acompanhamento dessa demanda é um direito legal da vítima ${ }^{10}$, pois não há um sistema geral de acompanhamento dessas denúncias em nível nacional, nem qualquer informação institucional sobre o levantamento dos dados de denúncias de crimes com motivação racial no Brasil.

A Ouvidoria Nacional da Igualdade Racial, da SEPPIR, acompanha a questão das denúncias do crime de racismo, sendo inclusive responsável por promover o acesso da população à Justiça nesses casos. Entretanto, não constam informações sobre o estabelecimento de parceria formal com o Ministério da Justiça no acompanhamento dessa demanda e da incorporação dessa demanda na SEPPIR como parte das ações de promoção da igualdade racial.

10 O Ministério Público de Pernambuco é uma referência na temática por ter constituído um Grupo de Trabalho específico contra o Racismo e ter publicado uma Cartilha com orientações para a vítima. 
Assim, ainda que seja a primeira das políticas de promoção da igualdade racial a possuir uma lei específica, o combate ao racismo no âmbito criminal é uma ação que carece de sistematização e coordenação de dados, a fim de efetivamente formar uma rede com uma série de atores e um conjunto de responsabilidades e ações que possam tornar efetiva a criminalização do racismo no País.

Outro ponto de extrema relevância para o debate, é a criminalização do racismo como solução para a repressão à discriminação racial no Brasil. Ainda que reste a incontestável conquista das entidades do movimento negro com a criminalização da discriminação racial como ação governamental, é discutível a eficiência dessa medida para o que ela visa combater. A mera inserção dessa questão no Código Penal, numa sociedade racista institucionalmente como a brasileira, ocasiona o fato acompanhado pelo LAESER: a extrema inefetividade dessa ação, fazendo com que os poucos cidadãos que procuram a Justiça para denunciar a discriminação percam suas ações.

\subsubsection{Políticas valorizativas}

No período de 1988 a 2000, é possível observar o ensejo de políticas versando sobre a questão racial principalmente no âmbito da cultura e do reconhecimento das comunidades quilombolas. Em 1988 houve a criação da Fundação Cultural Palmares pela Lei n. 7.665/1988, com o objetivo de promover ações na área da cultura afro-brasileira, africana e diaspórica e para certificar as comunidades quilombolas no Brasil.

Assim, no PPA de 2000 a 2003, a única menção a programas que versam sobre a questão racial, ou negra, é o Programa Cultura Afro-brasileira, sob a responsabilidade da Fundação Cultural Palmares, o qual tinha como objetivo promover a valorização da cultura negra no Brasil, por meio do apoio e fomento a projetos culturais 
afro-brasileiros, do reconhecimento, demarcação e titulação de comunidades quilombolas. Dentre as ações desenvolvidas no âmbito do programa no período, são destaques a identificação de 724 comunidades remanescentes de quilombos, sendo 43 oficialmente reconhecidas e 18 tituladas. E o apoio a eventos sobre a questão racial à restauração de referenciais culturais afro-brasileiros.

No período seguinte, de 2004 a 2007, o Programa Cultura Afro-brasileira deixou de ser completamente responsável pela regularização fundiária quilombola. $\mathrm{O}$ programa ainda abrangia algumas ações destinadas às comunidades quilombolas referentes à capacitação de docentes para atuarem nessas comunidades e apoio jurídico; porém a ênfase nas ações foi totalmente voltada à questão cultural, com apoio a projetos nessa área e a implantação de centros de referência culturais afro-brasileiros.

A partir de 2004 a questão quilombola ganha um programa específico: o Programa Brasil Quilombola (PBQ), uma iniciativa governamental que visa aglutinar as políticas públicas destinadas ao segmento social quilombola dentro de um só programa de governo, estabelecendo que a coordenação e o acompanhamento dessas ações devem ser realizados pela SEPPIR.

Dentre as diretrizes do $\mathrm{PBQ}$, destacam-se a implementação de ações governamentais nas comunidades dentro de um modelo de gestão para a igualdade, o estímulo ao protagonismo das comunidades no processo decisório das ações, a promoção do acesso à rede de proteção social e aos direitos, merecendo destaque os direitos territoriais, relativos ao reconhecimento, regularização e titulação das comunidades.

Mesmo com o recente período de vigência do programa, é impossível falar do $\mathrm{PBQ}$ sem indicar os sérios problemas de execução e o fracasso retumbante no seu principal objetivo: garantir a titularidade das terras às comunidades. É importante destacar que 
a regularização fundiária, além de demanda histórica das entidades dos movimentos negros e quilombola, é ponto de partida para algumas ações previstas no plano, no que tange à instalação de equipamentos públicos nas comunidades.

O processo de regularização de uma comunidade quilombola passa por uma série longa de etapas. Primeiro a comunidade deve ser certificada pela Fundação Cultural Palmares, depois deve ser iniciado o processo no Instituto Nacional de Colonização e Reforma Agrária (INCRA), responsável por elaborar um Relatório Técnico de Identificação e Delimitação (RTID), que inclui a elaboração de relatório antropológico, levantamento fundiário, planta e memorial descritivo, assim como o cadastramento das famílias quilombolas; depois o RTID deve ser publicado, em seguida há a abertura de contraditório para interessados e julgamento de possíveis contestações ao RTID; depois o INCRA deve publicar a portaria de reconhecimento do território; depois deve haver a decretação do território como de interesse social; depois ocorre a desintrusão dos ocupantes não quilombolas com pagamento de indenização pela terra nua e pelas benfeitorias; na sequência é realizado georreferenciamento e cadastramento do território no SNCR; e finalmente a titulação e registro do título emitido.

Atualmente, há 2.024 comunidades quilombolas certificadas no Brasil pela Fundação Cultural Palmares, dessas comunidades somente 206 possuem o título de suas terras. Atualmente há 1.193 processos abertos no INCRA para a regularização fundiária de comunidades. Considerando que no período de 2003 a 2011 o governo federal emitiu 13 títulos no âmbito do $\mathrm{PBQ}$, seguindo esse ritmo, os processos abertos até 2013 no INCRA seriam efetivados no ano 2819.

De 2004 a 2011 esteve vigente o Programa Educação para a Diversidade e Cidadania (PPA 1377) do Ministério da Educação, 
que consistia na organização de uma série de ações que objetivavam promover a diversidade na educação e o acesso equitativo de diversos segmentos sociais à educação. Esse programa partia da premissa de que a escola pode ser um lócus de disseminação de conceitos e práticas que negam a diversidade brasileira, sendo necessárias ações específicas para habilitar os profissionais da educação a tratar com as temáticas dessa diversidade e para promover o acesso à educação a grupos sociais historicamente alijados do processo educacional no País.

No PPA 2008-2011, são definidos os seguintes objetivos para o Programa Educação para a Diversidade e Cidadania:

Objetivo de Governo: Propiciar o acesso da população brasileira à educação e ao conhecimento com eqüidade, qualidade e valorização da diversidade.

Objetivo Setorial: Promover a educação para a diversidade e o fomento ao exercício da cidadania como direito público subjetivo.

Objetivo do Programa: Reduzir as desigualdades étnico-racial, de gênero, de orientação sexual, geracional, regional e cultural no espaço escolar. (BRASIL, 2007).

Se por um lado o objetivo do governo versa sobre o acesso ao conhecimento para a diversidade, o qual é reforçado pelo objetivo setorial, o objetivo do programa em si é pouco claro, uma vez que as desigualdades étnico-racial, de gênero, orientação sexual, geracional, regional e cultural podem se apresentar de diversas formas no ambiente escolar.

É possível que haja disparidade racial e de gênero entre os professores e demais profissionais da educação, objetivo para o qual o programa não possui ações; não há nenhuma indicação de ações para reduzir as desigualdades geracionais no espaço escolar; é extremamente enganoso afirmar desejar reduzir a "desigualdade 
cultural", uma vez o objetivo do programa é promover a diversidade a fim de alcançar uma educação plural. Contudo, há possivelmente um problema de terminologia, sendo o real objetivo o nivelamento do conhecimento difundido na rede educacional.

As áreas abrangidas pelo escopo do programa eram a Educação do Campo, Educação Escolar Indígena, Educação das Relações Étnico-raciais, Gênero e Ações Educativas Complementares. Os indicadores do programa, segundo o Relatório Anual de Avaliação do PPA 2004-2007, são:

[...] índices de igualdade, que permitem identificar e mensurar desigualdades e assimetrias sócio-educacionais, tais como: as desigualdades étnico-raciais; de gênero e identidade de gênero; a assimetria entre a população do campo e as áreas urbanas; a população indígena; a população remanescente de quilombos; a alfabetização e a educação de jovens e adultos e outras populações consideradas em situação de vulnerabilidade e risco social. (BRASIL, 2007).

Contudo, não está explícita, nem no PPA, nem nos relatórios de avaliação dos Planos Plurianuais 2004-2007 e 2008-2011, a metodologia de cálculo de tais índices. De acordo com a definição apresentada no resultado do PPA 2004-2007, esse índice é avaliado mediante a proporção de estudantes de determinado segmento diante do total de estudantes, o que é extremamente complexo. No que tange à questão de gênero na educação, é importante explicitar o que vem a ser esse índice de igualdade, uma vez que escolarização das mulheres já é mais elevada que a masculina na educação básica, mas ainda há elevados índices de evasão no ensino médio. Observadas as variáveis sexo (masculino) e raça (negra) essa evasão é muito elevada. 
No caso específico da educação do campo, indígena e quilombola, há uma legislação específica que assegura uma educação diferenciada com escolas nas comunidades. Assim, além da proporção de estudantes, é necessário avaliar a rede de oferta de serviços de educação específicos para esses segmentos, a formação de docentes, a qualidade do material didático, entre outros fatores.

A educação das relações étnico-raciais era realizada no âmbito do programa, sendo que suas principais atividades, consistiam na capacitação de profissionais da educação para a implementação do previsto na Lei 10.639/2003 em sala de aula.

É importante destacar que, em 2005, houve uma série de ações no âmbito da formação para a educação das relações étnico-raciais. Além do lançamento dos dois programas, que são objetos de análise desta pesquisa, houve a publicação de uma série de livros de referência sobre relações étnico-raciais, no âmbito da então Secretaria de Educação a Distância, Alfabetização e Diversidade (SECAD) e também uma série de eventos e atividades a serem pormenorizadas no próximo capítulo.

No PPA 2012-2015, a educação das relações étnico-raciais aparece nominalmente no Programa: 2016 - Políticas para as Mulheres: Enfrentamento à Violência e Autonomia, com as metas de formação de 140 mil profissionais pelo Programa Gênero e Diversidade na Escola e de 40 mil gestoras e gestores em políticas públicas nas temáticas de gênero e relações étnico-raciais e a partir da publicação da Portaria n. 1.328, de 23 de setembro de 2011, a formação dos docentes em parceria com as Instituições Públicas de Ensino Superior passou a ser realizada pela Rede Nacional de Formação Continuada dos Profissionais do Magistério da Educação Básica Pública.

De certa forma, a questão da educação das relações étnico-raciais possui uma controvérsia complexa em relação às demais 
políticas de promoção da igualdade racial apresentadas, como o PBQ e as ações afirmativas estimuladas pela SEPPIR no âmbito das áreas setoriais: educação, saúde, trabalho, cultura, etc. A duplicidade dessa ação, como política educacional e de promoção da igualdade racial, deveria indicar uma dupla coordenação, porém na prática a decisão das ações tende a pender para o lado da educação. Contudo, a análise do conjunto dessas ações será pormenorizada no Capítulo 2.

Este capítulo teve como objetivo traçar um panorama das políticas de promoção da igualdade racial, a fim de indicar como elas estão organizadas e quais as potencialidades e deficiências apresentadas até então por meio de um exercício teórico, a partir do conceito de políticas de promoção da igualdade racial de Jaccoud e Beghin (2002) e da procura por ações nos PPA.

Ainda que ao longo de todo o capítulo seja destacado o processo de intensa relação da incorporação da questão racial nas ações governamentais por meio das demandas da militância negra, observa-se uma grande imprecisão na legislação que versa sobre esse tema, ora padecendo de nebulosidade para definir a população negra como foco, ora com um grande escopo de ações com pouco conteúdo prático do alcance dos objetivos.

Nesse contexto, a aprovação do Estatuto da Igualdade Racial foi um grande ponto de embate entre essa militância que possibilitou a existência dessa política - e consequentemente da institucionalidade que a coordena - e o governo.

No que tange especificamente às ações, é importante destacar que muitas possuem legislação específica. As ações repressivas são amparadas em lei, a educação das relações étnico-raciais e as ações afirmativas têm lugar nas IES, e as ações voltadas às comunidades quilombolas são reguladas por decreto. 
Por fim, não é demais reafirmar que há o desafio da adoção de ações afirmativas para além das universidades e há, também, indícios de sérios problemas em ações voltadas às comunidades quilombolas e na efetivação da criminalização do racismo. 


\section{Educação das relações étnico-raciais (s)em perspectiva}

O processo de constituição da educação das relações étnico-raciais como política pública é completamente paralelo à composição das políticas de promoção da igualdade racial, como observado no capítulo anterior. É possível afirmar que o ponto de afluência dessa política é a aprovação da Lei 10.639/2003, ocorrida no mesmo período de diversas legislações que estabelecem e organizam as políticas de promoção da igualdade racial no Brasil. Contudo, no contexto das políticas educacionais, essas ações relativas à temática étnico-racial são recentes. $\mathrm{O} M E C$ possui mais de 80 anos de existência, enquanto a Secretaria de Educação Continuada, Alfabetização, Diversidade e Inclusão (SECADI) ${ }^{11}$ foi criada em 2004, mas somente a partir da Constituição Federal de 1988 há a

11 Quando criada, a Secretaria chamava-se Secretaria de Educação Continuada, Alfabetização e Diversidade (SECAD), instituída formalmente por meio do Decreto n. 6.320, de 20 de dezembro de 2007. Contudo, aos poucos foi sendo incorporada a questão da inclusão da pessoa com deficiência no escopo de suas ações, e no Decreto n. 7.480, de 16 de maio 2011, houve a oficialização da mudança de nome para SECADI. 
atribuição ao Estado da obrigação pela universalização do ensino fundamental no País. A constituição anterior, de 1967, estabelecia a corresponsabilização entre pais, empresas e poder público pela universalização do ensino primário (correspondente atualmente da segunda a nona séries do ensino fundamental); o ensino secundário (ensino médio) não era obrigatório, sendo gratuito aos comprovadamente pobres. Nesse contexto, no final da década de 1980, quando houve a promulgação da Constituição, a situação educacional do País era uma população adulta - com 15 anos ou mais de vida - com uma média de cinco anos de estudos, sendo que $20 \%$ dessa mesma população com menos de um ano de estudo e $20 \%$ completamente analfabeta (IBGE, [20--]).

Segundo Moreira (1990), até a década de 1920 não havia uma proposta curricular única e sistemática no Brasil. Nessa década, mais de $85 \%$ da população era analfabeta e aos que alcançassem o nível educacional secundário o currículo era um conjunto de matérias literárias e acadêmicas com caráter eminentemente elitista $\mathrm{e}$ enciclopédico. A partir dessa década, foram iniciadas reformas em alguns estados - São Paulo, Bahia e Minas Gerais -, com ênfase na alfabetização.

$\mathrm{Na}$ Bahia, houve uma reorganização da educação com uma coordenação curricular - o que por si só era revolucionário - realizada por Anísio Teixeira. O currículo escolar foi organizado de modo a formar o cidadão, com os conhecimentos e habilidades necessários à convivência em sociedade.

Em Minas Gerais, a reforma proposta pelos educadores Mário Casassanta e Francisco Campos sugeria um modelo de organização escolar de preparação para a vida em sociedade, de modo que as atividades realizadas no ambiente escolar refletissem os desafios e organização da sociedade especialmente por meio de metodologias de ensino (trabalhos em grupo, integração aluno e professor, etc). 
Os educadores - Anísio Teixeira, Mário Casassanta e Francisco Campos - são considerados os pioneiros do currículo escolar brasileiro. Suas contribuições são importantes para caracterizar o currículo como instrumento de transmissão de conhecimentos importantes do conjunto da sociedade.

A partir do Estado Novo, a questão curricular é institucionalizada nacionalmente com a criação do Ministério de Educação e Saúde. Essa institucionalização ganha importância ainda mais específica com a criação do Instituto Nacional de Estudos e Pesquisas Educacionais (INEP), na década de 1950, com a nomeação de Anísio Teixeira como diretor.

O INEP realizava cursos sobre currículo e editava uma revista sobre o tema, além de livros de referência para a formação docente sobre o currículo. $O$ conteúdo ministrado era definido de acordo com o considerado adequado ao meio social de inserção do aluno. Nesse sentido “[...] desejava-se um currículo que contribuísse para a coesão social, que formasse o cidadão de um mundo em mudança, e que atendesse às necessidades da ordem industrial emergente." (MOREIRA, 1990, p. 120).

As bases que estabeleciam o conteúdo mínimo ainda não eram nacionalmente definidas, o que ocorreu tão somente a partir de 1961, com a Lei 4.024, de 20 de dezembro de 1961, Lei de Diretrizes e Bases da Educação (LDB/1961). Com essa lei há o estabelecimento da flexibilização dos currículos, de matérias obrigatórias comuns no primeiro ciclo do grau médio da escola primária para o estabelecimento de um currículo mínimo, a definição da obrigatoriedade do ensino de línguas, história e literatura no nível ginasial. O autor indica as décadas de 1970 a 1990 como cruciais para a fundamentação do currículo no País tanto como disciplina acadêmica quanto como parte do planejamento educacional. 
Segundo Moreira (1997), não há um consenso a respeito do que vem a ser o currículo da educação. Na literatura são encontradas várias ocorrências com conceitos diferentes. De modo geral, o uso mais recorrente indica duas acepções mais comuns: uma referente ao conhecimento escolar planejado pela escola, que os alunos e alunas devem possuir, e outra referente ao conjunto de experiências de aprendizagem vivenciadas pelos alunos no ambiente escolar. Em ambas as acepções usadas, Moreira (1997, p. 11) destaca que:

[...] o currículo constitui significativo instrumento utilizado por diferentes sociedades tanto para desenvolver os processos de conservação, transformação e renovação dos conhecimentos historicamente acumulados como para socializar as crianças e os jovens segundo valores tidos como desejáveis.

Assim, basicamente, o currículo abarca tudo o que é considerado imprescindível para a formação do cidadão. Isso se tornou efetivamente mais assertivo no Brasil a partir da Constituição de 1988, que estabelece a necessidade de uma formação básica comum no ensino fundamental, cujo conteúdo mínimo vem a ser definido pela Lei n. 9.394, de 20 de dezembro de 1996, Lei de Diretrizes e Bases da Educação (LDB).

Somente a partir da LDB a educação é compreendida como um sistema que engloba: Educação Infantil, Educação Básica, Educação de Jovens e Adultos, Educação Profissional, Educação Superior e Educação Especial. Nessa lei a educação é classificada como dever do Estado, com igualdade de acesso e condições de permanência aos estudantes.

A Lei 10.639/2003 veio obrigar o ensino de Historia e Cultura-Brasileira e Africana na Educação Básica, alterando a LDB a fim de promover um currículo escolar antirracista e valorizativo da população negra. 
Este capítulo tem o objetivo de apresentar alguns levantamentos da implementação da educação das relações étnico-raciais na educação básica e no ensino superior, considerando que uma relação de complementaridade entre educação básica e superior é fundamental para a implementação da lei.

No primeiro tópico é feita uma contextualização da educação das relações étnico-raciais explicando o processo de construção dessa política e indicando ações que foram desenvolvidas. Para tanto, será analisado o processo legislativo da aprovação da Lei 10.639/2003 e da legislação e regulamentações subsequentes que versam sobre a temática.

Num segundo momento, será apresentado um panorama da educação das relações étnico-raciais na Educação Básica por meio das pesquisas "Práticas Pedagógicas de Trabalho com Relações Étnico-Raciais na Escola na Perspectiva da Lei 10.639/2003” e "Raça e Classe na Gestão da Educação Básica Brasileira”, ambas com a pesquisa de campo realizadas em 2009.

Nesse mesmo capítulo, será analisado o processo $n$. 00041.000247/2010-20 da SEPPIR, que realizou um levantamento com as IES sobre a implementação da educação das relações étnico-raciais.

A partir da organização e sistematização das informações desse processo, será feira uma proposta de indicadores de implementação.

\subsection{Educação das relações étnico-raciais: breve histórico}

A questão sobre o papel da escola e a questão racial - ou o papel da escola na questão racial - são temas observados na legislação ainda antes da Constituição de 1988. Na LDB/1961, já havia a coibição de tratamento diferencial na escola baseado na raça. 
Segundo Dias (2005), a despeito da menção à rejeição à discriminação na LDB de 1961, não houve ações de acompanhamento dessa norma e também não se observou avanço nas legislações educacionais subsequentes, como a Lei n. 5.540, de 28 de novembro de 1968, a qual fixava normas de organização e funcionamento do ensino superior e sua articulação com a escola média, e a Lei n. 5.692, de 11 de agosto de 1971, revogada, a qual fixava as Diretrizes e Bases para o ensino de $1^{\circ}$ e $2^{\circ}$ graus.

A partir da Constituição de 1988, há uma nova etapa no desenvolvimento das políticas de educação. $\mathrm{O}$ texto constitucional classifica a educação como política social universal, com o objetivo de formar os estudantes para a vida e para o mercado de trabalho. Há também a ratificação do princípio da igualdade, do padrão de qualidade e do respeito à diversidade.

A educação com respeito à diversidade é uma meta institucional proposta na Constituição e reforçada posteriormente na LDB. Segundo o texto original da lei, o currículo escolar deve ter uma base comum que condiga com os valores culturais do País e o respeito às características regionais no currículo específico de cada região. Também é indicada a necessidade do ensino da história do Brasil que inclua e contemple a participação de pessoas negras e indígenas em sua formação.

A questão racial ganha algum destaque no que tange ao aspecto curricular dentro do debate da educação, principalmente em razão da participação de entidades do movimento negro e de organizações indígenas na proposição de políticas públicas. A LDB estabelece que o ensino de história deva considerar as matrizes africanas, indígenas e européias da formação do Brasil. Para Dias (2005) essa inclusão:

É muito pouco, diante de toda a produção existente sobre a tensão no Brasil no que se refere à raça e, em 
especial, às condições da população negra, mas representa um avanço, se considerada a total omissão no projeto apresentado pelas entidades dos professores.

De 1989 a 1996 foram promulgadas sete leis de estados, municípios e do Distrito Federal instituindo a inclusão da história afro-brasileira no currículo escolar. São elas: a Constituição do Estado da Bahia, de 5 de outubro de 1989; a Lei Orgânica do Município de Belo Horizonte, MG, de março de 1990; a Lei n. 6.889, de 5 de setembro de 1991, do Município de Porto Alegre, RS; a Lei n. 7.685, de 17 de janeiro de 1994, do Município de Belém, PA; a Lei n. 2.221, de 30 de novembro de 1994, do Município de Aracaju, SE; a Lei n. 2.639, de 16 de março de 1998, do Município de Teresina, PI, e a Lei n. 1.187 de 13 de setembro de 1996, do Distrito Federal (SANTOS, 2005).

Segundo Augusto dos Santos (2005), em virtude da aproximação de entidades do movimento negro e de representantes políticos das esferas municipais e estaduais, a inclusão da temática entendida hoje como educação das relações étnico-raciais foi transformada em legislação antes da iniciativa federal.

Estimulados pelo mesmo tipo de aproximação mencionada acima, em 11 de março de 1999, os então Deputados Federais Esther Grossi (PT/RS) e Ben-hur Ferreira (PT/MS) apresentaram na Câmara dos Deputados o Projeto de Lei 259, apresentado em 11 de março de 1999, o qual instituía a obrigatoriedade na rede oficial de educação do ensino de história e cultura afro-brasileira e dava outras providências. A redação oficial dos principais aspectos do projeto de Lei era a seguinte:

Art. $1^{\circ}$ Nos estabelecimentos de ensino de primeiro e segundo graus, oficiais e particulares, torna-se obrigatório o ensino sobre História e Cultura Afro-Brasileira. 
$\int 1^{\circ} \mathrm{O}$ conteúdo programático a que se refere o caput deste artigo incluirá o estudo da História da África e dos Africanos, a luta dos negros no Brasil, a cultura negra brasileira e o negro na formação da sociedade nacional, resgatando a contribuição do povo negro nas áreas social, econômica e política pertinentes à História do Brasil.

$\int 2^{\circ}$ Os conteúdos referentes à História e Cultura Afro-Brasileira serão ministrados no âmbito de todo o currículo escolar, em especial nas áreas de Educação Artística e de Literatura e História Brasileiras.

$\S 3^{\circ}$ As disciplinas de História do Brasil e Educação Artística, no ensino de $2^{\circ}$ grau deverão dedicar pelo menos $10 \%$ de seu conteúdo anual ou semestral na temática da lei.

Art. $2^{\circ}$ Os cursos de capacitação para professores deverão contar com a participação de entidades do movimento afro-brasileiro, das universidades e de outras instituições de pesquisas pertinentes à matéria.

Art. $3^{\circ} \mathrm{O}$ calendário escolar incluirá o dia 20 de novembro como 'Dia Nacional da Consciência Negra'. (PROJETO DE LEI 259, 1999).

Para justificar a proposição da lei, os deputados alegavam que a educação difundida no País era eurocêntrica, culminando com a perpetuação do ensino de uma história do Brasil que não condizia com a experiência da população no território brasileiro.

Durante três meses o projeto foi analisado na Comissão de Educação, Cultura e Desporto da Câmara Legislativa, sendo disponibilizado em maio do mesmo ano para emendas, porém nenhuma foi proposta. Em agosto, o relator, o então Deputado Evandro Milhomen, encaminhou parecer "favorável" ao projeto, o qual foi aprovado unanimemente pela Comissão e encaminhado para a Comissão de Constituição e Justiça e de Redação, a qual também não apresentou-lhe emendas. $\mathrm{O}$ relator, Deputado André Benassi, considerou constitucional a proposição, apenas 
suprimindo um artigo formal, não alterando em nada o conteúdo do projeto de lei, tendo sido seu voto acompanhado pela Comissão. Uma vez aprovado pelos deputados na Câmara Legislativa, o Projeto foi para o Senado Federal.

No Senado, o projeto foi encaminhado para a Comissão de Educação, tornando-se o Projeto de Lei Complementar n. 17/2002. O relator, Senador Gerald Cândido, emitiu parecer favorável à aprovação, a partir das desigualdades raciais no País analisadas pelo Instituto de Pesquisa Econômica Aplicada (Ipea), inclusive por causa dos desdobramentos da Conferência de Durban. O Projeto, aprovado pela Comissão de Educação, foi então encaminhado à Comissão Diretora, a qual manteve o conteúdo original na redação oficial.

Contudo, consultado pela Comissão Diretora do Senado, o MEC manifestou-se pelo veto de duas propostas, a do $\$ 3^{\circ}$ do artigo $1^{\circ}$, que estabelecia que o conteúdo da educação africana e afro-brasileira deveria conter pelo menos $10 \%$ do conteúdo das disciplinas de História do Brasil e Educação Artística, e o artigo 2º, que indicava a necessidade de participação de universidades, instituições de pesquisas e entidades do movimento negro nas capacitações aos docentes.

O MEC alegou que a obrigatoriedade desse percentual mínimo de $10 \%$ de inserção de assuntos sobre africanas e afro-brasileiras no currículo era contrária ao princípio de respeito aos valores culturais regionais e locais na definição do conteúdo mínimo. Segundo o Veto Parcial 04/2003 ao PLC 17/2002

Ao descer ao detalhamento de obrigar, no ensino médio, a dedicação de dez por cento do seu conteúdo programático à temática mencionada, o referido parágrafo não atende ao interesse público consubstanciado na exigência de se observar, na fixação dos currículos mínimos de 
base nacional, os valores sociais e culturais das diversas regiões e localidades do país. (MEC, 2003).

O uso dessa argumentação para rejeitar a proposta é questionável, uma vez que a população negra está presente em todo o País, e ainda que não estivesse, a base de uma educação antirracista e valorizativa à população negra seria um elemento importante do currículo nacional, ainda que pudesse não haver população negra significativa em algumas localidades. Deve-se inclusive destacar que esse limite mínimo de $10 \%$ seria restrito às disciplinas de História do Brasil e Educação Artística. A indicação de que a definição da base comum do currículo deva partir da anuência e participação dos estados é um argumento importante, contudo é equivocado afirmar que somente a definição do percentual mínimo fere a necessidade de garantir a participação das "diversas regiões", ao invés de todo o Projeto de Lei.

No que tange à participação de entidades do movimento negro, universidades e institutos de pesquisa especializados na temática racial na formação de docentes, o MEC apresentou razões para o veto do artigo, alegando que a $\mathrm{LDB}$ não versa sobre como deve ser a formação docente, fazendo com que esse artigo ficasse deslocado dentro da lei. De fato, não é possível observar nenhum item da LDB que verse sobre como deve ser a formação docente.

Assim, em nove de janeiro de 2003, a Lei 10.639/2003 foi promulgada, mantendo-se os vetos indicados pelo MEC. Contudo, ainda assim, a lei promoveu a inserção da história e cultura africana e afro-brasileira, porém sem estabelecer um limite temporal para a sua implementação, nem o mínimo dessa inserção no currículo. No entanto, a partir de sua aprovação, foi aberto espaço para uma série de definições, pareceres, resoluções e ações do MEC, no que viria a se chamar educação das relações étnico-raciais. 
Destaca-se que mesmo com a retirada de algumas propostas em virtude da intervenção do MEC, o texto da Lei 10.639/2003 contempla integralmente a proposição expressa pelo MNU na Convenção do Negro na Constituinte em 1986, que indicava: "É obrigatória a inclusão nos currículos escolares de $1^{\circ}$ e $2^{\circ}$ graus, do ensino de História da África e da História do Negro no Brasil." (Convenção do Negro na Constituinte, 1986).

A definição sobre como deve ser uma educação para as relações étnico-raciais é construída a partir do Parecer CNE/CP 03/2004, de 10 de março de 2004 e da Resolução n. 1, de 17 de junho de 2004. Essa Resolução foi elaborada por meio da consulta a especialistas no tema, entidades dos movimentos negros, conselhos estaduais e municipais de educação, professores e alunos. A resolução é destinada aos profissionais da educação e dos sistemas de ensino, gestores de políticas e programas educacionais e à sociedade brasileira (estudantes e suas famílias). Nela, relações étnico-raciais são caracterizadas como relações entre pessoas negras e brancas. ${ }^{12}$

Os objetivos da educação das relações étnico-raciais são possibilitar o reconhecimento de pessoas negras na cultura brasileira a partir de seu próprio ponto de vista, promover o conhecimento da população brasileira sobre a história do Brasil com a visão de mundo da população negra, formar os professores para ministrarem disciplinas que contemplem a perspectiva negra na história, cultura e sociabilidade do País assim como que saibam combater e discutir sobre o racismo e seus efeitos (dentro e fora do ambiente escolar), e finalmente propiciar a reeducação para relações étnico-raciais plurais e diversas.

12 Apesar de o Parecer classificar relações raciais estritamente como sendo entre pessoas negras e brancas, há diversas indicações, no próprio Parecer e em outros documentos do MEC, de que as relações raciais são entre todas as raças e etnias. Contudo, o conteúdo referente à educação das relações étnico-raciais é focado na cultura negra e africana. 
Desse modo, essa resolução acompanha a recomendação de entidades do movimento negro realizada no Documento da Marcha Zumbi dos Palmares, contra o Racismo, pela Cidadania e pela Vida, de que o governo brasileiro desenvolva “[...] programas permanentes de treinamento de professores e educadores que os habilite a tratar adequadamente com a diversidade racial, identificar as práticas discriminatórias presentes na escola e o impacto destas na evasão e repetência das crianças negras." (MARCHA Zumbi..., 1995).

Em 2009, foi publicado o Plano Nacional de Implementação das Diretrizes Curriculares Nacionais da Educação das Relações Étnico-raciais e para o Ensino de História e Cultura Afro-brasileira e Africana, Lei 10.639/2003, sistematizado por meio das contribuições de diversos encontros regionais.

O Plano atribui responsabilidades e competências e também resgata o arcabouço legal que embasa a educação das relações étnico-raciais. Entre as atribuições do governo federal, o plano estabelece diversas ações, entre as quais podem ser apontadas as seguintes:

a) Incluir as Diretrizes Curriculares Nacionais para Educação das Relações Etnicorraciais e Ensino de História e Cultura Afro-Brasileira e Africana e os conteúdos propostos na Lei 11645/2008 nos programas de formação de funcionários, gestores e outros (programa de formação de conselheiros, de fortalecimento dos conselhos escolares e de formação de gestores).

b) Incluir na Política Nacional de Formação dos Profissionais do Magistério da Educação Básica, sob a coordenação da CAPES, as Diretrizes Curriculares Nacionais para Educação das Relações Etnicorraciais e História da África e Cultura Afro-Brasileira e Africana, com base no Parecer CNE/CP n. 03/2004 e Resolução CNE/CP n. 01/2004 e a Lei 11645/08.

c) Incluir como critério para autorização, reconhecimento e renovação de cursos superiores, o cumprimento do 
disposto no Art. $1^{\circ}, \mathbb{S} 1^{\circ}$ da Resolução $\mathrm{CNE} / \mathrm{CP}$ n. $01 / 2004$.

d) Reforçar junto às comissões avaliadoras e analistas dos programas do livro didático a inclusão dos conteúdos referentes à Educação das Relações etnicorraciais e à história da cultura afro-brasileira e africana, assim como a temática indígena, nas obras a serem avaliadas.

e) Apoiar e divulgar a Ouvidoria da SEPPIR para questões Etnicorraciais, na área de educação.

f) Encaminhar o Parecer CNE/CP n. 3/2004, a Resolução CNE/CP n. 01/2004, a Lei n. 11645/2008 e este Plano aos conselhos universitários, sublinhando a necessidade do cumprimento dos preceitos e orientações neles contidos.

g) Incluir questões no Censo Escolar sobre a implementação das Leis 10639/2003 e 11645/2008 e aplicação das Diretrizes Curriculares Nacionais da Educação das Relações Etnicorraciais em todos os níveis e modalidades de ensino da educação básica.

h) Desagregar os dados relativos aos resultados das avaliações sistêmicas (Prova Brasil, ENEM, ENADE), assim como as informações do Censo Escolar sobre fluxo escolar (evasão, aprovação, distorção idade/série/ciclo e concluintes acima de 15 anos de idade) por escola, município e estado a partir de recortes por perfis socioeconômicos, etnicorraciais e de gênero.

i) Divulgar os dados coletados e analisados (escolas e estruturas gerenciais das secretarias estaduais e municipais, MEC), de forma a colaborar com o debate e a formulação de políticas de eqüidade.

j) Promover ações de comunicação sobre as relações etnicorraciais com destaque para realização de campanhas e peças publicitárias de divulgação das Leis 10639/2003 e $11645 / 2008$ e de combate ao preconceito, racismo e discriminação nos meios de comunicação, em todas as dimensões.

k) Promover, de forma colaborativa, com estados, municípios, Instituições de Ensino Superior e Entidades sem 
fins lucrativos a Formação de Professores e produção de Material Didático para atendimento das Leis 10639/2003 e $11645 / 2008$.

1) Criar mecanismos de supervisão, monitoramento e avaliação do Plano, conforme Resolução $\mathrm{CNE} / \mathrm{CP}$ n. 01/2004;

m) Instituir e manter comissão técnica nacional de diversidade para assuntos relacionados à educação dos afro-brasileiros, com o objetivo de elaborar, acompanhar, analisar e avaliar políticas públicas educacionais, voltadas para o fiel cumprimento do disposto nas Leis 10639/2003 e 11645/2008, visando a valorização e o respeito à diversidade etnicorracial, bem como a promoção da igualdade etnicorracial no âmbito do MEC. (BRASIL, 2009).

Destaca-se que, das doze atribuições do governo federal, não são encontradas ações para o item c, "Incluir como critério para autorização, reconhecimento e renovação de cursos superiores o cumprimento do disposto no Art. $1^{\circ}, \int 1^{\circ}$ da Resolução CNE/ CP n. 01/2004.", e para o item e, "Apoiar e divulgar a Ouvidoria da SEPPIR para questões Etnicorraciais, na área de educação". O item c será avaliado no tópico a seguir, mas de modo geral não há nenhum acompanhamento sistemático da formação dos docentes nas universidades com atenção à educação das relações étnico-raciais, e o item e é totalmente anômalo ao conjunto do documento, pois a Ouvidoria da SEPPIR é a Ouvidoria Nacional da Igualdade Racial, definida no Estatuto da Igualdade Racial como unidade para o acolhimento e atendimento de denúncias de racismo por parte da população. O plano não indica como e para que essa ouvidoria deva ser apoiada, nem como ou para que ela deva ser divulgada para questões étnico-raciais na área da educação.

Uma questão importante para se realizar qualquer avaliação sobre as ações que versam sobre educação das relações étnico-raciais é que nenhum dos instrumentos legais estabelece a atuação do 
MEC, da SEPPIR, dos órgãos de educação estaduais e municipais ou das instituições de ensino, nem institui prazos ou metas. ${ }^{13}$

Dessa forma, não há no referido Plano um horizonte com parâmetros de implementação, isto é, prazo para que todos os professores estejam aptos a ministrar o conteúdo, nem estimativa para que todos os livros comprados pelas escolas tenham os conteúdos inclusivos.

\subsection{Panoramas, painéis e indicadores}

$\mathrm{Na}$ presente seção são apresentadas principais avaliações nacionais sobre a implementação da educação das relações étnico-raciais bem como são sistematizados e analisados registros da consulta às instituições de ensino superior realizada pela SEPPIR.

\subsubsection{Educação básica}

A partir dos documentos publicados pelo MEC, não é possível precisar quantas e quais escolas implementam de forma plena a educação das relações étnico-raciais na Educação Básica em nível nacional. É preciso ponderar que tal informação tem uma dimensão considerável de apuração, considerando que o Brasil possui 146.241 instituições de ensino fundamental e 26.944 de Ensino Médio (MEC/INEP/DEED, 2011). Outros problemas importantes

\footnotetext{
13 A legislação que estabelece e execução da educação das relações étnico-raciais é composta por: Lei n. 10.639/2003, Lei n. 11.645/2008, o Parecer CNE/CP 003/2004, a Resolução CNE/CP 01/2004 e o Plano Nacional de Implementação das Diretrizes Curriculares Nacionais da Educação das Relações Étnico-raciais e para o Ensino de História e Cultura Africana e Afro-brasileira. O plano estabelece um prazo para o seu acompanhamento e consequentemente, a resposta do poder público com as ações realizadas, contudo, não indica metas objetivas com relação ao contingente ou proporção de instituições aptas a ministrarem o conteúdo da educação das relações étnico-raciais em prazos determinados.
} 
são qual modelo de avaliação contempla esse tipo de política, quais indicadores são relevantes, como obter essa informação de forma confiável e, a partir dela, quais ações possíveis de serem executadas.

Jannuzzi et. al. (2009) aponta algumas críticas a avaliações de políticas governamentais, entre as quais resumidamente podemos destacar: i) diversas avaliações contratadas pelo próprio governo tem um caráter generalista, não sinalizando as imprecisões conceituais do programa; ii) muitas pesquisas tem baixo poder explicativo, ou não podem ser generalizadas para o conjunto dos casos semelhantes; iii) há programas em estágios muito iniciais de implementação, cuja avaliação prematura já parte com o diagnóstico da não implementação.

No dia 23 de janeiro de 2012, o Instituto de Advocacia Racial e Ambiental - IARA, protocolou uma ação no Supremo Tribunal Federal requerendo a suspensão de diversos cursos superiores em virtude da não implementação da educação das relações étnico-raciais. $\mathrm{Na}$ ação os autores afirmam que o MEC não tem regulado a implementação da educação das relações étnico-raciais no Ensino Superior, solicitando, assim, providências da Presidenta da República.

Entretanto, entende-se que para afirmar categoricamente se as IES têm efetivamente implementado ações, faz-se necessário considerar as diversas ações indicadas para a implementação da política, além de realizar diagnóstico da situação dessa temática nas instituições, anteriormente à aprovação da legislação, a fim de estabelecer uma linha de base para comparação.

Destaca-se inclusive que, se a educação básica, que está sujeita a mais formas de controle e acompanhamento nos âmbitos federal, estadual e municipal não possui um diagnóstico quanto à implementação da educação das relações étnico-raciais, menos ainda tem o ensino superior, um vez que as instituições públicas têm maior autonomia e as particulares recebem pouco acompanhamento. 
Porém, em 2009 foram realizadas duas pesquisas com essa finalidade. Ambas se enquadram nos estudos definidos como os de "baixo poder de generalização" (JANNUZZI et. al., 2009, p. 102) que, apesar de não indicarem o status nacional da implementação, levantaram indicadores e casos a serem exemplificados.

Destaca-se que as pesquisas têm sua ênfase na escola como lócus de implementação e no impacto das ações das secretarias municipais de educação, não se aprofundando na relação entre as ações realizadas nas escolas e nas secretarias com as ações em curso na gestão nacional da política de educação.

Uma das pesquisas, que neste trabalho serve de subsídio, financiada pelo MEC: "Práticas Pedagógicas de Trabalho com Relações Étnico-Raciais na Escola na Perspectiva da Lei n. 10.639/2003", realizada no âmbito do Programa de Ensino, Pesquisa e Extensão Ações Afirmativas na Universidade Federal de Minas Gerais e do Núcleo de Estudos e Pesquisas sobre Relações Étnico-Raciais e Ações Afirmativas (NERA/CNPq).

$\mathrm{O}$ objetivo da pesquisa foi analisar a implementação da educação das relações étnico-raciais na educação básica. Para isso foram selecionadas escolas por meio das secretarias estaduais e municipais de educação, de acordo com as informações constantes no Plano de Ações Articuladas (PAR) sobre a "Formação inicial e continuada de professores da Educação Básica para cumprimento da Lei n. 10.639/2003".

O PAR é um instrumento de gestão educacional, no qual são inseridas uma série de informações das instituições. A metodologia de pesquisa considerou que o preenchimento dos quesitos relativos à educação das relações étnico-raciais no PAR era um indicador relevante. Contudo, é mister destacar que as instituições podem preencher esses itens no PAR e não desenvolverem tais ações efetivamente, conforme foi observado em alguns casos, ou, então, não 
preencherem adequadamente o PAR e possuírem ações concretas de implementação.

Foram solicitadas também indicações dos NEAB e dos selecionados pelo Prêmio "Educar para a Igualdade Racial”, realizado pela organização social Centro de Estudos das Relações de Trabalho e Desigualdades (CEERT). Assim, de acordo com o Relatório, foram selecionadas instituições distribuídas da seguinte forma:

Considerando os informantes-chave, contabilizou-se um total de 825 indicações de escolas (555 indicadas pelas Secretarias Municipais de Educação, 194 pelas Secretarias Estaduais de Educação e 76 pelos NEABs). Foram também selecionadas 65 escolas premiadas pelo CEERT em uma das três primeiras edições. Ao todo 890 escolas foram indicadas pelos atores-chave: 232 na Região Sul; 340 na Região Sudeste; 61 na Região Centro-Oeste; 138 na Região Nordeste (sendo 107 na Regional Nordeste I e 31 na Regional Nordeste II); e 119 na Região Norte. (MEC, 2010, p. 78).

Desse conjunto, foram selecionadas 36 escolas para participarem da pesquisa. Essa redução ocorreu porque muitas das escolas selecionadas não possuíam os indicadores de implementação definidos pela pesquisa, e, também, houve recusa de participação de algumas instituições, e outras não foram encontradas.

Os indicadores de implementação selecionados pela pesquisa foram: tempo de implementação (excluindo-se as escolas com tempo inferior a um ano); percentual de professores que desenvolvem atividades referentes à educação das relações étnico-raciais; quantidade de modalidades educacionais em que a temática está inserida e a sua incorporação no projeto político-pedagógico (PPP) da escola.

Como resultado, encontrou-se um grande desnível em termos de implementação entre as escolas. E essa resposta é extremamente 
complexa porque foram selecionadas exatamente as instituições que: i) acreditam já implementar as ações de educação das relações étnico-raciais; e ii) são referenciadas por outras instituições como exemplos de implementação.

Ainda que esse panorama não tenha representado, de forma alguma, a tentativa de uma análise do contexto nacional a partir das escolas visitadas, tal estudo de caso apontou para um horizonte de dificuldade de implementação da política, sendo que o grau de comprometimento e entendimento dos docentes quanto ao que significa ministrar o conteúdo da educação das relações étnico-raciais foi um dos fatores de convergência nos dados encontrados.

De modo geral, os professores e professoras que entendem e ministram o conteúdo são intimamente ligados à temática, por se considerarem negros e negras e/ou militarem em prol da questão racial. Assim, o estudo conclui que

Por mais distante da perspectiva da Lei e das Diretrizes Curriculares Nacionais que uma prática observada pudesse ser, não se pode dizer que a temática étnico-racial fosse totalmente desconhecida pelo conjunto de profissionais entrevistados(as). Isso não quer dizer que a equipe da coordenação regional não tenha encontrado educadores(as) com profundo desconhecimento da Lei n. 10.639/2003, mas um fato deve ser apontado: o grau de ignorância em relação à temática racial está relacionado com a postura pessoal e política dos profissionais das escolas. As entrevistas de educadores(as) resistentes à implementação da Lei nas escolas, sobretudo aqueles(as) que ocupam o lugar da gestão e da coordenação pedagógica revelam não somente a introjeção do racismo ambíguo e do mito da democracia racial os quais resultam em visões preconceituosas, estereotipadas e até mesmo racistas sobre a questão africana e afro-brasileira como também visões e posturas conservadoras sobre a educação e a prática da gestão de maneira mais geral. 
Ou seja, a pesquisa aponta que o enraizamento de práticas pedagógicas na perspectiva da Lei em escolas cuja direção e/ou coordenação são conservadoras e autoritárias tende a ser muito mais fraco. As iniciativas pedagógicas existentes ficam a critério de um(a) professor(a) específico(a) e algumas vezes de um pequeno coletivo de docentes (negros e brancos, mas na sua maioria negros), comprometidos com a questão racial. (MEC, 2010, p. 459).

Nesse mesmo ano, a pesquisadora Renísia Cristina Garcia Filice realizou a pesquisa "Raça e Classe na Gestão da Educação Básica Brasileira" como requisito para a obtenção do doutorado na UnB. O objetivo da pesquisa foi avaliar a implementação de Lei $10.639 / 2003$ a partir da perspectiva da gestão institucional no município, para tanto foram analisadas respostas de questionários aplicados aos gestores educacionais em períodos distintos de 2007 a 2009.

A pesquisa analisou 133 questionários que já haviam sido aplicados anteriormente, em 2007, pelo Núcleo de Estudos Negros em parceria com a União Nacional dos Dirigentes Municipais de Educação (Undime) para gestores municipais. Em 2009, foram aplicados novos questionários a um conjunto de gestores.

Ao longo da pesquisa, são agrupadas e comparadas as respostas das regiões, identificando uma pretensa implementação mais acentuada na região Sudeste em detrimento das demais. Todavia, ainda que a pesquisa ressalte a distribuição regional (todas as regiões tiveram algum município que respondeu a pergunta), esse conjunto de respostas não é representativo para realizar tal constatação, uma vez que não foi realizada amostra para realizar generalizações, além de não haver equivalência entre a quantidade de respostas das regiões e a quantidade de municípios, ou populacional ou de instituições educacionais. 
Nessa fase, observou-se que muitas das secretarias municipais que afirmam ter implementado a educação das relações étnico-raciais realizam atividades esparsas e pouco articuladas com o currículo. Os principais motivos alegados pela não implementação, das que admitem não fazê-lo são a falta de material e de capacitação aos professores ${ }^{14}$.

Ainda que ambas as pesquisas não possam ser parâmetros para um diagnóstico básico, elas indicam sérios problemas de implementação. Basicamente, a inclusão dos conteúdos ocorreu somente de forma parcial, quando ocorreu nas instituições, e a questão da capacitação dos docentes, ou mais especificamente a ausência, como um eixo-central para a efetivação da implementação.

\subsubsection{Educação superior}

Ainda que a Lei 10.639/2003 obrigue exclusivamente a inclusão da educação das relações étnico-raciais na Educação Básica, há uma relação direta entre a educação superior e a básica, condicionando o sucesso da inclusão de um currículo na educação básica à sua entrada na formação de docentes nas licenciaturas.

O Parecer CNE 03/2004 compartilha a responsabilidade de inclusão das temáticas entre a Educação Infantil, a Básica, Superior e de Jovens e Adultos. O Parecer estabelece: i) que as IES devem implementar a educação das relações étnico-raciais, pois possuem autonomia para compor seus projetos pedagógicos e disciplinas, podendo ser estabelecidas parcerias com entidades, inclusive dos

\footnotetext{
14 Ressalta-se que, num segundo momento, foi aplicado outro questionário, solicitando informações sobre as ações que o município desenvolve, e também sobre o conhecimento do gestor sobre o que vem a ser a educação das relações étnico-raciais. Contudo, esse segundo questionário foi aplicado em um grupo ainda menor e tinha o foco na percepção do gestor da questão como fator relevante para a gestão da política.
} 
movimentos negros, para auxílio na implementação; ii) que o ensino pode dar-se por projetos de diversas naturezas, não necessariamente em disciplinas; iii) que os NEAB podem auxiliar na seleção de conteúdos e procedimentos de ensino e de aprendizagens.

Sobre as IES, o Plano Nacional de Implementação estabelece as seguintes responsabilidades:

a) Incluir conteúdos e disciplinas curriculares relacionados à Educação para as Relações Etnicorraciais nos cursos de graduação do Ensino Superior, conforme expresso no $\$ 1^{\circ}$ do art. $1^{\circ}$, da Resolução CNE/CP n. 01/2004.

b) Desenvolver atividades acadêmicas, encontros, jornadas e seminários de promoção das relações etnicorraciais positivas para seus estudantes.

c) Dedicar especial atenção aos cursos de licenciatura e formação de professores, garantindo formação adequada aos professores sobre História e Cultura Afro-Brasileira e Africana e os conteúdos propostos na Lei 11645/2008.

d) Desenvolver nos estudantes de seus cursos de licenciatura e formação de professores as habilidades e atitudes que os permitam contribuir para a educação das relações etnicorraciais com destaque para a capacitação dos mesmos na produção e análise critica do livro, materiais didáticos e paradidáticos que estejam em consonância com as Diretrizes Curriculares para Educação das Relações Etnicorraciais e para o Ensino de História e Cultura Afro-brasileira e Africanas e com a temática da Lei 11645/08. e) Fomentar pesquisas, desenvolvimento e inovações tecnológicas na temática das relações etnicorraciais, contribuindo com a construção de uma escola plural e republicana.

f) Estimular e contribuir para a criação e a divulgação de bolsas de iniciação científica na temática da Educação para as Relações Etnicorraciais.

g) Divulgar junto às secretarias estaduais e municipais de educação a existência de programas institucionais 
que possam contribuir com a disseminação e pesquisa da temática em associação com a educação básica. (BRASIL, 2009).

Em 2010, a SEPPIR realizou uma consulta às IES solicitando informações sobre a implementação da educação das relações étnico-raciais. Foram enviados ofícios a 856 instituições. O ofício solicitava que as instituições informassem:

Cópia do conteúdo de disciplinas e atividades curriculares dos cursos ministrados contendo "Educação das Relações Étnico-Raciais” como disciplina, bem como do tratamento de questões e temáticas que dizem respeito aos afrodescendentes, nos termos explicitados no Parecer CNE/ CP 3/2004. (art. 10 da Resolução n. 01, de 17 de junho de 2004, do Conselho Nacional de Educação).

Informações sobre ações, metas e prioridades para constar no PLANAPIR - Plano Nacional de Promoção da Igualdade Racial - Decreto 6.872/2009, art. 4o, inciso I, II e III. Experiências práticas de implementação da Lei da História da África e Cultura Afro-brasileira e indígena, que, a seu juízo, possam ser encaminhadas pela Ouvidoria da SEPPIR para o monitoramento do PLANAPIR. (SEPPIR, 2010).

Destaca-se que, em 2010, o Brasil possuía 2.378 IES (INEP, 2012), assim, essa consulta realizada pela SEPPIR abrangeu $36 \%$ do conjunto das instituições. Não houve uma definição dos critérios de seleção das IES, porém foram consultadas todas as universidades federais.

Os ofícios foram enviados no período de 01/04/10 a 05/08/10. E as respostas foram recebidas de 05/2010 a 01/2011. Em virtude do volume do processo - que possui mais de 7 mil páginas - e de processos administrativos no âmbito da SEPPIR, as 
informações sobre o processo só começaram a ser sistematizadas a partir de setembro de 2012.

Somente 341 IES responderam ao ofício, ou seja, cerca de $40 \%$ das instituições selecionadas, e somente $14 \%$ do universo das IES do País. Desse modo, destaca-se que devido aos aspectos estatísticos da não realização de uma pesquisa censitária, nem de uma amostra representativa, não é possível a partir do resultado dessa consulta generalizar o conteúdo do processo para avaliar a implementação da educação das relações étnico-raciais em todas as IES no Brasil.

Das 856 instituições, 55 são universidades federais, dessas somente 26 responderam; 38 são universidades estaduais, das quais somente 16 responderam; e 763 são instituições privadas, sendo que 299 responderam. ${ }^{15}$

No que se refere aos aspectos metodológicos da consulta, não foram definidos pela SEPPIR nem o formato de organização das informações sobre as disciplinas, nem quais as atividades acadêmicas eram importantes serem informadas, pois foi considerado que as instituições de ensino sabiam de antemão o que era ministrar os conteúdos da educação das relações étnico-raciais. Essa falta de rigor na metodologia gerou discrepâncias bastante significativas nas respostas da IES. ${ }^{16}$

É importante destacar que definir o que é ministrar o conteúdo das relações étnico-raciais era essencial para qualificar a

\footnotetext{
15 Registre-se também que algumas das instituições informaram não formarem docentes, exatamente 29 faculdades.

16 Algumas instituições encaminharam uma página com a lista de disciplinas que consideravam atinentes, como a Universidade de São Paulo (USP) e outras mandaram processos com dezenas de páginas, com todas as atividades desenvolvidas nos últimos 5 anos, como a Universidade Federal Tecnológica do Paraná (UFTPR).
} 
resposta, porque muitas instituições crêem que qualquer disciplina que mencione a população negra ou a África pode se enquadrar na temática, sendo que a legislação explicita a necessidade de um conteúdo valorativo e ressignificativo à contribuição negra e africana. $\mathrm{O}$ mesmo se aplica às palestras, seminários e demais atividades acadêmicas e culturais. A definição prévia do formato de organização das informações a serem enviadas também era necessária, a fim de estabelecer parâmetro de comparação entre as instituições, mas isso também não ocorreu.

Assim, a partir de esforço de sistematização, as respostas das IES foram lidas e resumidas. E por fim, observou-se as respostas prevalentes, organizando-se as informações fornecidas em 15 categorias: i) Disciplinas Específicas; ii) Disciplinas transversais; iii) Atividades Acadêmicas sobre a temática racial; iv) Atividades de Extensão sobre a temática racial; v) NEAB ou Similar; v) Resolução da instituição sobre o tema; vii) Pesquisas sobre a temática; viii) Pós-graduação sobre a temática; ix) Cursos de extensão, atualização, mini-cursos sobre educação das relações étnico-raciais; x) Participação de docentes e técnicos da universidade em atividades sobre a temática ofertadas por outra instituição; xi) Publicações sobre a temática; xii) Fórum Estadual/Municipal Permanente de Educação e Diversidade; xiii) Semana da Consciência Negra; xiv) Eventos culturais; xv) Convênio com países Africanos.

Faz-se necessário enfatizar que informação mais precisa solicitada nos ofícios enviados foi sobre a presença de disciplinas que versassem em sobre a educação das relações étnico-raciais. ${ }^{17}$

17 Os ofícios enviados solicitavam a cópia do conteúdo das disciplinas e atividades curriculares contendo "Educação das Relações Étnico-raciais” como disciplina. Porém, não houve nenhuma orientação em documentos oficiais de que as disciplinas que versem sobre a temática supracitada devessem possuir em seu nome "Educação das Relações Étnico-raciais". O termo "Educação das 
Algumas instituições prestaram somente essa informação, mas isso não significa que elas não tenham publicações sobre a temática ou não desenvolvam outras atividades. Portanto, o dado quantitativo mais seguro em relação às atividades que as instituições desenvolvem é referente às disciplinas, os dados referentes à presença ou ausência de atividades acadêmicas, de extensão ou outras não são seguros por não terem sido citadas especificamente no ofício que realizou a consulta.

Duas categorias são destinadas às disciplinas. Das instituições que responderam, a maioria indica possuir disciplinas específicas. No entanto, ao se analisar as informações sobre conteúdo, observa-se que diversas não versam sobre temas específicos sobre a questão africana ou afro-brasileira. Assim, avaliou-se a resposta das instituições definindo como específicas as disciplinas que versassem sobre os temas definidos na Lei 10.639/2003: História da África e dos Africanos; Luta dos negros no Brasil; Cultura negra brasileira; e Negro na formação da sociedade nacional, que resgatam a contribuição do povo negro nas áreas social, econômica e política pertinentes à história do Brasil. Todas as demais foram consideradas transversais.

Em torno de $40 \%$ das instituições que responderam ao questionário afirmaram possuir disciplinas específicas, entre as quais as mais presentes são história(s) da África e literatura(s) africana(s). Aproximadamente $65 \%$ dos cursos informaram ter disciplinas transversais, e $60 \%$ cursos afirmam não possuírem nem disciplinas específicas nem transversais sobre a temática. A ocorrência desse evento pode se dever ao fato de que algumas instituições efetivamente não identificaram entre o seu rol de disciplinas nada

Relações Étnico-raciais” refere-se ao conjunto de temas relativos à questão racial, podendo, ou não, ser transformada em uma disciplina específica com esse nome. 
específico às relações étnicos-raciais. Já algumas instituições consideraram que todas as disciplinas das áreas humanas e/ou sociais contemplavam a questão racial.

De acordo com o Plano Nacional de Implementação, a realização de atividades acadêmicas sobre a temática racial são ações necessárias a serem realizadas pelas IES. Essas atividades são seminários, palestras e demais eventos acadêmicos que versam sobre a questão racial. Considera-se que a inserção de tal temática no calendário de atividades acadêmicas é parte da formação dos discentes, além de ser indicador da inserção geral da temática na instituição. As atividades mais citadas foram seminários e palestras, sendo que 100 instituições informaram realizar atividades acadêmicas sobre a temática, perfazendo a parcela de $29 \%$ das pesquisadas. Porém observando-se os estabelecimentos que possuem disciplinas transversais, ou específicas, ou atividades acadêmicas sobre a temática, chega-se ao total de 297 estabelecimentos, ou seja, $86 \%$ do total.

As ações de extensão são desenvolvidas no âmbito dos Projetos de Extensão de Ação Continuada ou atividades e eventos das Semanas de Extensão, ou em outras datas no contexto da extensão. Tal levantamento é importante para observar a disseminação do conhecimento sobre a temática das instituições para a comunidade. Somente 33 instituições informaram realizar atividades de extensão e entre as ações mais citadas destacam-se os Projetos de Extensão de Ação Continuada em temáticas relativas à cultura afro-brasileira.

A existência dos NEAB é um fator importante para a inserção da temática no ambiente acadêmico, especialmente no âmbito da pesquisa. Tal dado é extremamente relevante pelo fato de os NEAB serem parceiros em ações de capacitação do MEC no âmbito dos programas de formação de docentes, como o Uniafro. Apenas 17 estabelecimentos informaram seus NEAB como forma de implementação. Entre os similares foram citados Centros de 
Estudos Afro-orientados/PUC/SP18 e UFBA), Programa de Estudos e Extensão Afro-brasileiro - PROAFRO/PUC/GO ${ }^{19}$, Núcleo de Estudos em Educação e Relações Étnicas - NEERE/PUC/ $\mathrm{PR}^{20}$ ) e Núcleo de Identidade, Gênero e Relações Interétnicas Nigéria/Universidade Feevale/RS.

Duas instituições levaram a questão da educação das relações étnico-raciais para dentro de suas resoluções e normas a fim de coordenar a inserção da temática. Ainda que tal procedimento não seja essencial à efetivação da implementação, indica um sério grau de compromisso com a questão.

A presença de pesquisas sobre a temática, tanto na graduação quanto na pós-graduação, são importantes tanto para avaliar a produção do conhecimento sobre a questão, como para indicar o nível de inserção. $\mathrm{O}$ quantitativo de 41 instituições informou realizar pesquisas no âmbito da temática, sendo que a maioria foi no âmbito de monografias e trabalhos de conclusão de cursos na graduação.

Diversas instituições possuem pós-graduações sobre a temática. Fator fundamental para a formação de docentes nas IES aptas a formar profissionais da educação básica. Das 21 instituições que informaram ter programas de pós-graduação sobre a temática, 17 eram especializações e as demais eram programas stricto sensu.

Tal indicador encontra-se destacado porque muitos desses cursos são ofertados em parceria com as secretarias de educação estaduais, assim a instituição atua na formação do seu corpo discente e de docentes em atividade no sistema de educação estadual e municipal.

O quantitativo de 42 instituições informou ministrar cursos para a comunidade discente e externa sobre a temática da educação das relações étnico-raciais e da aplicação de conteúdos.

18 Pontifícia Universidade Católica/SP.

19 Pontifícia Universidade Católica/GO.

${ }^{20}$ Pontifícia Universidade Católica/PR. 
A capacitação do corpo discente na temática é um fator potencial para a formação dos estudantes. Porém algumas instituições ainda não possuem professores formados para tal, e investem em possibilitar ao seu corpo docente a capacitação em outras instituições: quatro instituições informaram propiciar ao seu corpo docente a capacitação em outras instituições de ensino.

Além de produzir pesquisas, algumas instituições têm possibilitado a publicação de textos acadêmicos sobre a temática, aumentando o potencial de disseminação do conhecimento. Nove instituições informaram publicar revistas sobre a temática.

Ainda que não seja uma questão essencial para mensurar como tem sido ministrado o conteúdo da temática no ensino superior, as instituições têm informado a participação nos fóruns de implementação da educação das relações étnico-raciais para indicar a participação do corpo docente da instituição na implementação em nível local. Somente cinco instituições informaram participarem dos fóruns de educação e diversidade.

Alguns estabelecimentos de ensino informaram a Semana da Consciência Negra ou atividades no dia 20 de novembro, eventos culturais, como o "dia do folclore" e convênios com países africanos como formas de inserção da temática em seus ambientes. Apenas 18 instituições informaram a comemoração da semana da consciência negra como forma de complementação da educação das relações étnico-raciais, sendo que, dessas, metade realiza atividades exclusivamente no dia 20 de novembro; 28 estabelecimentos informaram a realização de eventos culturais como forma de implementação e 9 instituições informaram os convênios e parceria com países para a concessão de bolsas para alunos africanos como forma de inserção da temática.

Para efeito da sistematização, é importante considerar todas as informações disponibilizadas pelas instituições consultadas, 
todavia tornar obrigatório determinado conteúdo na educação básica carece, necessariamente, de garantir a sua inserção no currículo da educação superior. No entanto, nem todas as categorias levantadas na pesquisa partem dessa premissa. A existência de atividades sobre a temática, ainda que importante instrumento de divulgação, não é tão relevante quanto uma disciplina específica, do mesmo modo que respostas categorizadas pouco dizem a respeito da formação do docente em relação a ministrar o conteúdo da educação das relações étnico-raciais. Assim, podemos agrupar esses indicadores pelo que eles efetivamente podem qualificar com relação às informações prestadas pelas IES.

Primeiramente, é preciso destacar que quase todas as instituições que responderam ao ofício, informaram implementar a educação das relações étnico-raciais. Até mesmo as 59 instituições que não possuem nem disciplinas específicas, nem disciplinas transversais. Contudo, ainda que uma IES convide palestrantes para eventos, no seu estabelecimento, em que a questão racial é tema, pergunta-se: essa iniciativa é suficiente para formar o docente a ministrar o conteúdo em sala de aula?

Ainda que essas categorias coadunem-se com a legislação, em que medida é possível saber se o aluno dessas instituições têm acesso às informações que podem ajudá-lo a incluir conteúdos da educação das relações étnico-raciais na sua prática docente?

Jannuzzi (2005, p. 138) define indicadores sociais como formas de medir um conceito abstrato. Assim, para o autor, "[...] indicadores apontam, indicam, aproximam, traduzem em termos operacionais as dimensões sociais de interesse definidas a partir de escolhas teóricas ou políticas realizadas anteriormente”.

Assim, a fim de transformar as categorias resultantes da consulta da SEPPIR em indicadores para o que se deseja avaliar na presente pesquisa, ou seja, a implementação da educação das relações 
étnico-raciais na formação de docentes, pode-se reagrupá-las a fim de tentar aproximá-las do que elas efetivamente mensuram.

A presença de disciplinas específicas é o principal indicador para a formação de docentes, uma vez que é a única que efetivamente garante o conhecimento sobre o conteúdo da educação das relações étnico-raciais.

Nesse caso, é importante observar que essa presença é diferenciada: há universidades com um rol extenso de disciplinas sobre a temática em diversas áreas, ${ }^{21}$ enquanto a maioria possui disciplinas restritas à história da África e literatura africana. Então, dentro dessa categoria há a possibilidade de hierarquização no que tange à quantidade de disciplinas, à diversidade temática e à obrigatoriedade para a conclusão do curso.

Outra categoria importante é a presença de pós-graduações sobre a temática, ainda que essas não formem docentes, os cursos específicos sobre temas da educação das relações étnico-raciais capacitam docentes já formados e formam professores para IES.

A presença de (i) disciplinas transversais; (ii) atividades acadêmicas; (iii) atividades de extensão; NEAB ou similar; (iv) pesquisas; (v) publicações; (vi) cursos de extensão, atualização, mini-cursos sobre a temática são indicadores de formação complementar, porque garantem a entrada da temática de modo geral e transversal no ambiente acadêmico.

\footnotetext{
${ }^{21}$ A Universidade Federal do Rio de Janeiro apresentou o maior número de disciplinas: Arte Africana Afro-brasileira; Tópicos Especiais em Dança e Cultura Afro-Brasileira; Dança Afro-brasileira; Tópicos especiais em Dança Afrobrasileira; Emergência dos Países Africanos; História da Arquitetura Africana; Laboratório de Pesquisa em África Austral; História da África Contemporânea I, II, II e IV; História da África I e II; O Negro no Pensamento Social; Geografia Regional da África; Literatura Africana de Língua Portuguesa I e II; Poesia Africana em Língua Portuguesa; Ficção Africana em Língua Portuguesa.
} 
Por outro lado, os cursos de extensão e atualização, assim como as especializações, podem medir a formação de docentes fora da comunidade universitária, visto que esse tipo de curso é muito procurado para a capacitação de docentes da rede pública de ensino temática, tópico a ser analisado no próximo capítulo, sobre o Uniafro.

A participação de docentes e técnicos das IES em atividades sobre a temática ofertadas por outra instituição ou no Fórum Estadual/Municipal Permanente de Educação e Diversidade e a existência de resolução da instituição sobre o tema indicam o grau de priorização dessa temática no contexto da IES. Contudo, esse fator engloba os demais, uma vez que todas as atividades desenvolvidas na instituição sobre a temática indicam em algum grau a priorização e/ou o compromisso com a implementação da educação das relações étnico-raciais.

E, por fim, as categorias relativas à comemoração da Semana da Consciência Negra, eventos culturais e convênio com países africanos tão somente indicam o grau de desconhecimento da instituição sobre a temática. Três instituições informaram como ação de implementação atividades referentes ao "folclore", ou seja, exatamente o oposto ao pretendido com a educação das relações étnico-raciais. Ainda que o dia da consciência negra esteja inserido no calendário da educação básica como forma de valorização da cultura e resistência negras e de Zumbi dos Palmares como herói nacional, uma IES informar esse tipo de inserção da temática é completamente anacrônico e pouco conectado ao grau de aprofundamento da temática que o ensino superior exige. E, por fim, os convênios com países africanos para a vinda de estudantes somente seriam relevantes se garantissem um intercâmbio real de conhecimento entre esses estudantes estrangeiros e os docentes e discentes da IES, mas essa ação não foi informada.

Assim, sugere-se para as avaliações da educação das relações étnico-raciais no ensino superior na formação de docentes nas licenciaturas, o Quadro 1: 
Quadro 1 - Indicadores

\begin{tabular}{|l|l|}
\hline $\begin{array}{l}\text { Indicadores de formação de } \\
\text { docentes }\end{array}$ & Indicadores de formação complementar \\
\hline Disciplinas específicas & Disciplinas transversais \\
\hline \multirow{2}{*}{$\begin{array}{l}\text { Pós-graduações sobre a educação } \\
\text { das relações étnico-raciais }\end{array}$} & $\begin{array}{l}\text { Atividades acadêmicas (seminários, } \\
\text { palestras, pesquisas) }\end{array}$ \\
\cline { 2 - 2 } & $\begin{array}{l}\text { Atividades de extensão (cursos, seminários } \\
\text { projetos) }\end{array}$ \\
\hline
\end{tabular}

Fonte: Elaborado pela autora desta obra

Os indicadores de formação de docentes são os que efetivamente capacitam os profissionais a ministrarem o conteúdo da educação das relações étnico-raciais de forma valorativa, pormenorizada, qualitativa e específica.

Ainda que a legislação que versa sobre a educação das relações étnico-raciais em nenhum momento indique a obrigatoriedade de disciplinas específicas ou obrigatórias sobre o tema, entende-se que a inclusão é mais qualitativa, na medida em que promovida por meio de disciplina, pois pode abordar a questão de forma específica e profunda, ou seja, não generalista e panorâmica.

Nesse caso, pode-se indicar que a instituição forma docentes de modo ideal, na medida em que ela possui disciplinas específicas nas áreas de pedagogia, história, artes, literatura e outras, e forma docentes de maneira básica, quando ela não possui disciplinas específicas em algumas dessas matérias em destaque na Lei 10.639/2003.

Sob esse ponto de vista, das 341 instituições que responderam à consulta da SEPPIR, somente possibilitam a formação de docentes de maneira ideal 3 instituições: a Universidade de São Paulo (USP), a Universidade Federal do Rio de Janeiro (UFRJ) e a Universidade Estadual do Rio de Janeiro (UERJ). 
As Pós-Graduações são um indicador de formação, porém desarticulado da licenciatura. Assim, elas influem tanto de formação suplementar, como no caso das ofertas de especializações a profissionais da educação, quanto de formação ao nível de pré-requisito de ingresso da docência superior.

É importante mencionar o elevado grau de desarticulação da existência de Pós-Graduações sobre a temática com a existência de disciplinas nas licenciaturas. Das 21 instituições que informaram possuírem Pós-Graduações sobre a temática, 10 não possuem nenhuma disciplina na graduação e/ou licenciatura sobre o tema.

Tal fato é extremamente incoerente para a efetivação dessa política. Ao mesmo tempo em que a instituição tem a expertise técnica necessária para ofertar a formação, ela opta por somente fazê-la na Pós-Graduação. Tal fator pode ser explicado tanto pela ausência de um acompanhamento dessa inclusão nas licenciaturas superiores, especialmente nas instituições privadas, quanto pela existência de demanda de formação nessa área, que gera a existência das especializações sobre a temática.

Os indicadores de formação complementar avaliam mais a inserção da temática na comunidade acadêmica. Na medida em que eles existam, há o debate e a possibilidade do desenvolvimento de um ambiente reflexivo acerca dos temas. Contudo, não é possível equivaler palestras e seminários à existência de uma disciplina formal, ou seja, o seu impacto na formação de docentes para ministrarem seus conteúdos é mais indireto, ainda que na formação em geral da comunidade acadêmica possa haver uma maior relevância.

De modo geral, as três pesquisas apresentadas, ainda que não avaliem nem comprovem a situação no País sobre a implementação, indicam problemas restritos ao universo pesquisado que corroboram as denúncias em nível nacional, como a do IARA.

A pesquisa "Práticas Pedagógicas de Trabalho com Relações Étnico-Raciais na Escola na Perspectiva da Lei 10.639/2003" 
destaca problemas no desconhecimento dos professores e da coordenação pedagógica das escolas em como abordar a temática, enquanto a pesquisa "Raça e Classe na Gestão da Educação Básica Brasileira" volta-se ao papel dos gestores municipais em virtude do seu também desconhecimento da questão. Por fim, a consulta da SEPPIR às IES indica que há inserção da temática em grande volume de instituições pesquisadas, porém, poucas desenvolvem um trabalho efetivamente qualitativo de formação, que possibilite aos professores condições para abordar a temática conforme a legislação determina.

Porém, esses indícios de resultado não são desarticulados da gestão da política educacional ou das de promoção da igualdade racial em nível nacional. Há ações de formação para educação das relações étnico-raciais coordenadas pelo MEC que dialogam com esse resultado.

Seria enganoso responsabilizar exclusivamente os professores e as escolas, ou as gestões estaduais e municipais de educação. Assim como indica o Plano Nacional de Implementação das Diretrizes Curriculares Nacionais da Educação das Relações Étnico-raciais e para o Ensino de História e Cultura Afro-Brasileira e Africana essa é uma responsabilidade compartilhada entre as três esferas federativas, somadas às instituições e seus profissionais. 
Capítulo 3

\section{Africanidades e Uniafro: experiências inconclusas}

A fim de articular as ações intersecionais das políticas de promoção da igualdade racial no âmbito da educação, em 2003 foi firmado Protocolo de Intenções entre o MEC e a SEPPIR, com o objetivo de desenvolver parcerias em programas e ações que versassem tanto sobre políticas valorizativas - implementação da educação das relações étnico-raciais e de educação antirracista -, quanto políticas compensatórias, como estímulo à adoção de ações afirmativas para acesso e permanência de pessoas negras nas escolas tanto na infância quanto na idade jovem e adulta.

No contexto desse protocolo, foram iniciados projetos, como o A Cor da Cultura, parceria entre MEC, SEPPIR e Fundação Cultural Palmares, financiado pela Petrobras e executado pela Fundação Roberto Marinho, com objetivo de produzir materiais de caráter valorativo à diversidade para as escolas do País; foi instituída a Comissão Técnica Nacional de Diversidade para Assuntos Relacionados à Educação dos Afro-Brasileiros (CADARA), com o objetivo de acompanhar, analisar e avaliar as políticas educacionais voltadas para a educação das relações étnico-raciais, além da 
realização de seminários e da indução à formação de fóruns permanentes de educação das relações étnico-raciais nos estados.

Em 2005, em uma parceria do Centro de Ensino a Distância da Universidade de Brasília (CEAD/UnB) com a Coordenação de Diversidade e Inclusão Educacional da SECADI, começou o processo de construção do curso a distância intitulado Programa de Formação Continuada em Educação e Relações Etno-raciais.

O objetivo do curso era capacitar 50 mil professores das redes estaduais e municipais de ensino a ministrar o conteúdo da educação das relações étnico-raciais. $\mathrm{O}$ material instrucional seria elaborado por professores da $\mathrm{UnB}$, que seriam também os coordenadores do curso, enquanto o CEAD seria responsável pela logística técnica e administrativa do curso à distância e da tutoria.

Tal curso veio a se chamar Educação Africanidades Brasil e foi realizado em 2006, formou cerca de quatro mil professores, e, apesar de algumas repescagens na tentativa de possibilitar a conclusão da primeira turma, não houve nenhuma reedição. No site do MEC não há nenhuma informação sobre esse curso. ${ }^{22}$

Nesse mesmo ano, 2005, o MEC firmou Acordo de Cooperação com os NEAB, e demais centros e núcleos correlatos das universidades públicas, para a execução do Programa Uniafro. O objetivo do programa era fortalecer a implantação dos NEAB e auxiliar a promoção de ações afirmativas voltadas à população negra.

A partir do Edital n. 01 do Uniafro, de 26 de abril de 2005, é possível assumir que apoiar ações afirmativas, no âmbito desse programa, significava apoiar ações de promoção da igualdade racial, uma vez que o edital previa o apoio a projetos em diversos eixos: i) publicação voltada à temática racial; ii) formação de

\footnotetext{
22 A única referência encontrada no site do MEC é uma matéria jornalística intitulada "Diversidade étnico-racial nas salas de aula", de 8 de maio de 2006.
} 
docentes para a educação das relações étnico-raciais; iii) apoio ao acesso e permanência de estudantes negros nas instituições públicas de ensino.

Quando o projeto de pesquisa que originou este estudo foi concebido, seu principal objetivo era analisar os programas Africanidades e Uniafro, considerando que o Africanidades teve uma única tentativa de implementação e o Uniafro continuava vigendo, ambos iniciados em 2005.

Porém, no decorrer da pesquisa, em 2012, foi confirmada pela Coordenação de Educação das Relações Étnico-raciais a não continuidade do Uniafro. Assim, se anteriormente a ideia era comparar os modelos de implementação desses dois programas a fim de encontrar razão para a descontinuidade e não do outro, agora, esse é um trabalho sobre dois programas finados.

Faz-se necessário destacar que o processo de levantamento de dados para a realização desta pesquisa foi extremamente difícil no que tange ao Africanidades. As informações não estão disponíveis, e foi necessário lançar mão da Lei n. 12.527, de 18 de novembro de 2011, Lei de Acesso à Informação, para obter o pouco material disponibilizado.

A pesquisa que originou esse capítulo teve dois níveis, de acordo com Gil, (2008): i) descritivo, a fim de apresentar o modelo de funcionamento e implementação dessas ações; ii) explicativo, a fim de entender o processo de constituição desses programas, relacionar seus objetivos com os problemas que eles visam sanar, com destaque para a necessidade de capacitação do corpo docente das instituições de ensino da educação básica para implementar a educação das relações étnico-raciais.

Ao realizar tal análise, buscar-se-á responder três perguntas: i) por que esses programas não tiveram continuidade? ii) Caso esses programas tivessem uma execução eficiente eles ajudariam a 
sanar o problema que visavam combater? iii) Qual aprendizado institucional que se pode extrair dessa experiência para a gestão dessa política? Para isso, serão analisados documentos administrativos referentes aos programas.

No caso do Africanidades, a análise parte do Projeto Básico do Programa de Educação Continuada em Ensino de História e Cultura Afro-brasileira e Africana, originário da Lei 10.639/2003, que gerou o programa, do Plano de Trabalho e do Relatório Físico-Financeiro, além de arquivos e das planilhas administrativas do CEAD/UnB.

A análise sobre o Uniafro ocorre por meio dos quatro editais datados de 2005, 2006, 2008 e 2009, das informações publicadas no Diário Oficial da União (DOU) sobre os processos seletivos e dos pareceres técnicos disponibilizados pelo MEC sobre os convênios com as universidades contempladas pelos editais.

\subsection{Africanidades}

Na presente seção serão apresentadas informações sobre o Africanidades a partir da análise de documentação do CEAD/ UnB, serão analisados o projeto, a execução e os resultados.

\subsubsection{O Projeto Educação Africanidades Brasil (Africanidades)}

O curso intitulado Projeto Educação Africanidades Brasil partiu da perspectiva de que a falta de formação dos docentes em atividade nas escolas era um entrave à implementação da educação das relações étnico-raciais.

No Projeto Básico, o curso tinha como objetivo “[... formar professores multiplicadores e outros profissionais da educação, com conhecimento sobre a História da África e do negro no Brasil, para que fossem capazes de formar cidadãos livres para pensar 
o País na perspectiva da afirmação de sua identidade." (CENTRO DE EDUCAÇÃO A DISTÂNCIA, 2006).

De abrangência nacional, o curso pretendia capacitar $50 \mathrm{mil}$ multiplicadores para atuar na formação dos discentes no que se refere à "cultura de matriz africana" em 4.500 escolas. Nessa ação era também objetivo a inclusão da perspectiva da diversidade cultural no projeto educacional das instituições de ensino.

Na prática, os alunos participariam de um curso de extensão a distância, com duração de quatro meses e 120 horas/aula. As aulas eram separadas por unidades temáticas, sendo cinco módulos com quatro temas cada um. $\mathrm{O}$ curso seria ministrado no Ambiente Virtual de Aprendizagem (AVA) utilizado pelo CEAD, o Moodle, um sistema de gerenciamento de cursos virtuais de código aberto. O conteúdo das aulas também seria impresso e o livro seria enviado para os alunos.

Foi montado Comitê Gestor do curso para acompanhar sua execução. O Comitê deveria ter representantes da SECADI/MEC, um do CEAD/UnB e da Faculdade de Educação da UnB, responsável também pela coordenação pedagógica do curso.

Foram contratados professores-conteudistas para elaborarem o material, professores-formadores para acompanhar o curso, e tutores para supervisionar as atividades e estabelecer a relação com os estudantes. O modelo de implantação do curso tinha a seguinte estrutura de pessoal: para cada um professor-formador deveria haver 17 tutores, e para cada tutor deveria haver 140 alunos.

Para a seleção das escolas participantes foram estabelecidos critérios, como: i) ter número mínimo de 500 alunos; ii) ser públicas; iii) localizada em capitais, em regiões metropolitanas ou em áreas com comunidades quilombolas; iv) ter computadores e acesso à Internet.

A partir da escolha das escolas, eram definidos pela Secretaria Municipal de Educação local em parceria com a direção da 
escola, os professores que participariam do curso. Foi estabelecido o quantitativo de sete professores por escola no caso das escolas da rede pública municipal e estadual, e seis professores no caso de escolas técnicas federais.

A partir dos critérios de seleção, foi definido um grupo de escolas a participarem do curso, inferindo-se por meio da documentação, que a definição dos critérios e o processo de seleção das escolas foram realizados pela gestão do curso. Depois foi encaminhado ofício-circular solicitando que as secretarias estaduais e municipais de educação indicassem um coordenador para o Projeto.

Houve seminários em cinco capitais e em uma cidade do Complexo Metropolitano Expandido de São Paulo para a sensibilização sobre a temática e a apresentação do curso, nesses encontros, gestores do Africanidades explicaram os critérios de seleção, o objetivo e modelo de funcionamento do curso. Foram realizadas reuniões em São Paulo, SP, Campinas, SP, Rio de Janeiro, RJ, Florianópolis, SC, Recife, PE, e Manaus, AM..$^{23}$

O coordenador do curso em cada município, indicado pela secretaria de educação local, era responsável por articular com as escolas a seleção dos professores, além de ele mesmo ser obrigado a participar do curso.

O Projeto também previa um processo elaborado de avaliação no qual os objetivos principais eram:

a) Acompanhar os cursistas de forma a garantir o seu direcionamento nas atividades de formação, fornecendo-lhes feedback.

b) Reduzir o índice de evasão.

c) Mensurar a evolução dos cursistas no processo de apren-dizagem.

23 Não foram disponibilizados relatórios sobre os seminários nem pelo Ministério da Educação, nem pelo CEAD/UnB. 
d) Aferir a eficácia do programa. (CENTRO DE EDUCAÇÃO A DISTÂNCIA, 2006).

O processo de avaliação previa as seguintes etapas: i) avaliação da capacidade da gestão em aderir ao curso; ii) avaliações de aprendizagem ao longo do processo; iii) avaliação do instrumental do curso, inclusive com realização de pesquisa qualitativa com grupo focal de tutores.

A Planilha Financeira indica um orçamento de $\mathrm{R} \$ 2.658 .637,48$ para atividades que incluem a confecção e produção do material, a gestão a administração do programa e o processo avaliativo. O cálculo dos custos é baseado nas 4.500 escolas, assim estimou-se um gasto de $\mathrm{R} \$ 140.500,00$ com despesas postais.

$\mathrm{Na}$ Planilha, há uma redução do quantitativo de alunos em relação ao Projeto Básico de 50 mil para 25 mil alunos. É estabelecida uma relação de 140 alunos por tutor, o que conferiu ao projeto um total de 179 tutores.

O Plano de Trabalho, de 22 de março de 2006, que estabeleceu convênio entre a Fundação Universidade de Brasília (FUB) e o MEC para a realização do curso denomina o título como Programa de Formação Continuada em Educação e Relações Etno-raciais. Nele, o Projeto é definido por um cronograma que estabelece a duração de dez meses, sendo os quatro meses iniciais dedicados ao planejamento e gestão, os meses 4 a 6 para produção do material didático, os quatro meses finais para a execução do curso, sendo que os dois últimos já contemplariam o processo de avaliação e certificação.

O Plano reduz inexplicadamente o escopo do curso, indicando em suas metas a capacitação de 11 mil educadores, e não os 25 mil previstos no orçamento ou os 50 mil do Projeto Básico ${ }^{24}$.

\footnotetext{
24 Reitera-se que a meta de capacitar 25 mil docentes é a base de cálculo do orçamento e da infraestrutura técnica e de pessoal do curso.
} 
No dia 17 de abril de 2006, o Projeto do curso foi encaminhado ao Conselho Deliberativo do CEAD. Contudo, essas informações foram inseridas em um formulário padrão para Projeto de Extensão: Curso a Distância ou via rede. Nele é definido o número de participantes de 20 mil a 25 mil pessoas, com a execução efetuando-se de janeiro a dezembro de 2006.

Os itens de despesa discriminados nesse formulário são $\mathrm{R}$ \$ 1.345.417,32 de pagamentos a terceiros, $\mathrm{R}$ \$ 58.000,00 de material de consumo e $\mathrm{R} \$ 331.590,00$ de despesas postais. Esses valores financeiros não são equivalentes aos da Planilha Financeira do curso, sendo que ambos os documentos já contam com a redução para 25 mil docentes formados.

\subsubsection{Execução e resultados}

Depois do processo de seleção das escolas e contato com as secretarias de educação para a seleção e indicação dos professores, houve dificuldade de adesão para o curso, especialmente no município de São Paulo.

A matrícula deveria ser realizada no site do CEAD, o qual gerou dificuldades técnicas relatadas pelos participantes ao realizarem a inscrição. Em junho de 2006, havia somente 15 mil professores matriculados no curso. Para o alcance da meta de $25 \mathrm{mil}$ professores, foram autorizadas as inscrições de mais do que sete professores por escola.

Até o início do curso estavam matriculados 26.054 profissionais de educação, de 26 estados e o Distrito Federal, em 704 municípios, contemplando 4.000 escolas.

Quando houve o término do curso, em dezembro de 2006, 1.103 alunos tinham enviado alguma(s) das atividades previstas. Contudo, somente 533 alunos haviam concluído o curso, gerando um índice de evasão de $98 \%$. 
Em 2007, o AVA foi aberto novamente para possibilitar que alunos que não tivessem concluído as atividades, enviassem o trabalho final. Nessa outra etapa foram aprovados 358 alunos.

É controverso o quantitativo de aprovados. Numa das planilhas do $\mathrm{CEAD}$, está registrada a informação que 4.056 alunos foram aprovados, 1.057 foram reprovados, três desistiram e uma aluna faleceu. Porém, somando esses quantitativos, não se chega aos 8.916 profissionais presentes na planilha. Número também bem distante dos mais de 26 mil matriculados.

O que está expresso é que foram emitidos 6.205 certificados, ${ }^{25}$ gerando um quantitativo de $23 \%$ de sucesso do curso.

\subsubsection{Uma experiência no Africanidades}

Fui contratada para trabalhar como tutora no Africanidades em outubro de 2006. Na época, havia uma colega ${ }^{26}$ que desistiu do curso e me indicou para ocupar sua vaga. A atribuição dos tutores era acessar ao AVA todos os dias e acompanhar os cursistas, sendo que 4 horas semanais poderiam ser trabalhadas no escritório do $\mathrm{CEAD}$ e as demais 16 horas poderiam ser efetuadas em home-office.

Eu era responsável pelo acompanhamento de 140 estudantes do Município de Viamão, no Rio Grande do Sul. Desses 140 alunos, 85 nunca haviam acessado à plataforma do Africanidades até aquele momento. Por meio de contato com os estudantes, foi verificado que mesmo os 55 que estavam ativos no AVA não estavam participando efetivamente do curso.

25 Considerando que as escolas que participaram do curso tinham entre seis e sete professores matriculados, no mínimo, é possível que o quantitativo de certificados seja referente à multiplicação do número de trabalhos entregues, 891, pela quantidade de professores em cada escola, chegando-se a essa quantidade de certificados. Contudo, é importante destacar que o curso era individual e, pretensamente, também a avaliação.

${ }^{26}$ A desistência se deu em virtude dos atrasos no pagamento da bolsa, que foi paga, naquele ano somente em dezembro, depois da conclusão do curso. 
O CEAD dispunha de infraestrutura telefônica para que os tutores contatassem os estudantes. Nas 4 horas semanais no CEAD, ligava-se para os alunos, para acompanhar a sua participação e, principalmente, tentar convencê-los a não desistirem do curso.

Mas ao final o índice de desistência da turma chegou aos 90\%. As causas dadas para a desistência eram: i) a falta de tempo para realizar as atividades; ii) as dificuldades de operacionalizar o AVA, pois muitos professores não tinham familiaridade com a ferramenta e precisavam de um suporte bem detalhado; iii) o desgaste com a coordenação do curso e os inconvenientes das trocas de tutores; iv) a discordância com o conteúdo, com destaque para a unidade que versava sobre religiosidade afro-brasileira; v) as tarefas eram realizadas "coletivamente" e somente um alunos por escola postava a atividade.

Ao final do contrato de tutoria, no dia 10 de janeiro de 2007, foi enviado o Relatório Final do Curso à CEAD/UnB, porém depois disso não houve mais contato da $\mathrm{CEAD}$ seja para atuação dessa tutoria na repescagem em 2007, seja sobre a avaliação com tutores.

\subsubsection{Análise}

É importante destacar que esse curso foi a primeira tentativa de implementação de capacitação no âmbito federal da educação das relações étnico-raciais. Era um projeto ambicioso e inovador, na medida em que mais que efetivamente formar professores, a ideia era formar multiplicadores como disseminadores desse conteúdo.

Sendo essa a primeira capacitação promovida pelo MEC no âmbito da implementação da educação das relações étnico-raciais, é notável a ausência de uma análise pormenorizada dessa experiência, identificando quais seus avanços e suas limitações.

Resta evidente que esse Projeto não foi exitoso na sua expressão mais quantitativa, que é o percentual de alunos concluintes. 
Contudo, essa é somente uma das questões problemáticas que podem ser encontradas desde a concepção à execução do Projeto. Para analisar essas questões, dividiu-se em tópicos, destacando algumas questões na concepção, no desenho do curso, no modelo de gestão e execução.

A primeira questão que chama atenção no curso é o objetivo de formar 50 ou 25 mil multiplicadores na temática de educação das relações étnico-raciais. Qual a razão para esse quantitativo? É orçamentária? Esse valor foi estipulado baseado em quê? Não foi possível saber o motivo por meio da pesquisa. O que parece evidente é que era necessário fazer um projeto piloto com um quantitativo menor para testar as condições do CEAD de monitorar e realizar o curso, para depois, a partir desse resultado, realizar a expansão.

Ainda nesse aspecto quantitativo, pouco foi explicitado nos documentos consultados com relação aos seis ou sete professores por escola. Havia a definição de que eles deveriam ser de "diversas áreas", mas sem nenhuma especificação, sendo que no processo de alcance do quantitativo mínimo para o início do curso, quando foi aumentado o número máximo de professores por escola, não foi informada a continuidade dessa determinação. Não seria mais proveitoso no primeiro momento formar preferencialmente os professores das disciplinas obrigadas pelo texto da Lei 10.639/2003 (artes, literatura e história), para depois expandir ao conjunto de docentes?

Outra questão controversa nesse objetivo é a categoria "multiplicador" como objeto de um curso de capacitação para a implementação da educação das relações étnico-raciais. A inclusão desse conteúdo na legislação visa exatamente a qualificação da abordagem dessa temática. Assim, cada disciplina escolar, especialmente história, português, literatura e artes, deveriam incluir temáticas específicas, além de revisarem suas metodologias e pressupostos teóricos. 
Essa capacitação deveria ser um substitutivo da ausência de formação nessas temáticas desses docentes, quando estudantes de licenciatura. No entanto, capacitar profissionais da educação para capacitarem outros professores nesse tema, não é necessariamente considerar a complexidade e a especificidade da questão, mas sim pensar em termos de disseminação da temática, sem necessidade de tratamento específico. Essa é uma questão essencial para a concepção desse curso. Em que medida fazer uma capacitação para que professores se tornem professores de outros sobre determinado tema é incluir esse tema de forma qualitativa dentro da escola?

Outra questão bastante problemática é referente às condições de ser efetivamente um multiplicador, para isso, seria necessária uma estrutura para que esses multiplicadores disseminassem o conteúdo aprendido no curso com horas-aula para tanto, com definição de modelo de disseminação, com prazos e com estratégias.

E por fim, frisa-se: quem voluntariamente atribuiria a si mesmo a responsabilidade, não só de fazer o curso, mas de disseminá-lo na escola sem nenhuma garantia de infraestrutura de disseminação?

Essa pode ser uma das causas do baixo índice de matrículas observado no primeiro momento. Porém, para analisar inclusive esse fator, é importante observar o modelo de seleção das escolas.

Ainda que, no processo de implementação, a execução possa ter se afastado do Projeto Básico, a documentação apresentada indica que o grupo gestor do Africanidades selecionou as escolas, com base nos indicadores, e depois dessa seleção, entrou em contato com as secretarias de educação estaduais, para ser um ponto focal com as escolas.

Contudo, sem qualquer discordância com os critérios de escolha das escolas, a maneira como o curso foi apresentado, em uma forma já pronta, sem agregar as contribuições dos sistemas estaduais e municipais de ensino pode ter dificultado a sua aplicação. 
Além de não agregar essas secretarias à gestão e à concepção do Projeto, foi solicitado a esses órgãos, um trabalho extremamente difícil no momento da implementação, articular e acompanhar a participação dos docentes no curso.

O modelo do curso, que previa 140 alunos por tutor, já é uma grande sobrecarga para os tutores, que, em tese, trabalhariam 20 horas por semana. Assim, proporcionalmente, cada aluno teria 8 minutos semanais da dedicação do tutor para estimulá-los a participarem das atividades, analisar seus comentários, corrigir as atividades, prestar apoio técnico para a utilização das ferramentas presentes no AVA, quando necessário.

Quando da realização do Africanidades, não havia ainda a Portaria Normativa n. 2 do MEC, de 19 de janeiro de 2007, que dispõe sobre os procedimentos de regulação e avaliação da educação superior na modalidade a distância. E quando foi criado o Projeto, em novembro de 2005, não tinha sido publicado o Decreto n. 5.622, de 19 de dezembro de 2005, que regulamenta a Educação a Distância (EAD) na LBD.

Porém, ambos os instrumentos normativos não se aplicam ao Africanidades, devido ao curso ser de extensão. Contudo, é interessante observar o que esses instrumentos legais instituem, porque se esses procedimentos devem ser aplicados aos cursos de graduação e pós-graduação em EAD visando uma melhor qualidade de aplicação, talvez esses critérios pudessem se aplicar igualmente aos cursos livres.

O Decreto 5.622/2005 prevê obrigatoriedade das seguintes atividades presenciais, nos cursos a distância: i) avaliação discente; ii) estágios obrigatórios; iii) defesa de trabalhos de conclusão de curso e atividades laboratoriais. No caso dos cursos de graduação ou pró-graduação, tais atividades são diluídas ao longo de diversos meses, no caso de um curso de somente quatro meses, talvez um 
momento presencial no início fosse essencial para reforçar esse vínculo da participação do curso.

A Portaria Normativa 02/2007 estabelece que para a instituição ser credenciada para oferta de cursos de $\mathrm{EAD}$, ela deve dispor de "[...] estrutura física e tecnológica e recursos humanos adequados e suficientes”. A Portaria também consolida o polo presencial, como obrigatório para realização das atividades, consideradas como "[...] desenvolvimento descentralizado de atividades pedagógicas.” (BRASIL, 2007).

De modo geral, é possível afirmar que essa legislação sobre EAD garanta exatamente que esses cursos não sejam 100\% a distância, prevendo momentos presenciais e estrutura física no município ou na Unidade da Federação onde é ofertado, a fim de possibilitar a materialização da coordenação o mais próxima possível do domicílio do estudante.

É possível afirmar que a coordenação do Africanidades estava tentando desenvolver a aproximação que a legislação iria garantir posteriormente ${ }^{27}$ ao estabelecer contato com as secretarias estaduais e municipais de educação. Contudo, essa estrutura não fazia parte da gestão do curso. Talvez a incorporação efetiva das secretarias no Projeto seja uma questão importante a ser avaliada. Contudo, essa avaliação não é tarefa fácil, haja vista que a ausência dos relatórios de execução e acompanhamento da memória institucional do que foi o curso é talvez uma das suas maiores lacunas de implementação.

A EAD tem passado por uma grande expansão nos últimos dez anos. Porém, ainda possui índices de evasão superiores ao en-

27 Destaca-se que o fato de a legislação garantir a existência dos polos presenciais como parte da coordenação pedagógica dos cursos não significa que atualmente nos cursos a distância tal obrigação seja cumprida. 
sino presencial no País (SOUZA, 2009). Ao analisar a evasão nos cursos de EAD no ensino, Conceição Aparecida Nascimento de Souza destaca alguns motivos principais dessa evasão, são eles: i) a insatisfação com o tutor; ii) a dificuldade de acesso à Internet; iii) a complexidade das atividades; iv) a dificuldade de assimilação das ferramentas da EAD; v) as falhas na elaboração dos cursos; vi) as expectativas equivocadas por parte dos alunos; vii) a tecnologia inadequada ou falta de habilidade para usá-la corretamente.

É interessante observar que a formação docente pela EAD tem sido um grande foco de ações no Programa Universidade Aberta do Brasil do MEC. Talvez a principal questão do destaque nessa modalidade de ensino seja pela sua possibilidade de escala. De modo geral, os cursos são montados por uma equipe de especialistas e depois são operacionalizados por tutores ${ }^{28}$ com a supervisão de um professor formador. Assim um curso a distância, ainda que tenha um elevado custo tecnológico, tem um menor custo em recursos humanos, infraestrutura física e de material e administrativo.

Essa é a solução para a formação em larga escala de docentes? Esse parece ser uma prioridade de ações do MEC na gestão 2011-2014. Entretanto, infelizmente, a experiência do Africanidades parece apontar para um problema específico nesse modelo, relacionado às seguintes questões: i) a inserção do conteúdo das relações étnico-raciais no formato de curso EAD é valorativa para a temática? ii) é mais eficiente para capacitar os mais de 2 milhões de professores existentes atualmente em sala de aula? iii) como acompanhar a efetividade dessa capacitação na formação dos discentes e dos docentes?

${ }^{28}$ Os tutores são pessoas formadas que devem ter experiência docente, terem concluído ou estarem matriculadas em programas de pós-graduação. Os tutores recebem subsidio pago pelo Fundo Nacional de Desenvolvimento da Educação (FNDE), cujo valor era de $\mathrm{R} \$ 700$ reais. 


\subsection{Programa de Ações Afirmativas para a População Negra nas Instituições Federais e Estaduais de Educação Superior (Uniafro)}

A presente seção é dedicada à análise pormenorizada do Uniafro a partir da definição da concepção do projeto, a execução, os resultados e a análise da estratégia de política pública adotada.

\subsubsection{Projeto}

O Edital n. 01, de 26 de abril de 2005, da Secretaria de Educação Superior/ Departamento de Políticas da Educação Superior, foi o primeiro do Uniafro. Nele era estabelecida a parceria entre a SECAD e a Secretaria de Educação Superior na convocação das instituições públicas de ensino superior a apresentarem propostas de ensino, pesquisa e extensão universitária, por meio de seus NEAB e congêneres. Foram definidos os seguintes objetivos e eixos para as ações, no Edital 01:

Objetivos:

O objetivo geral do UNIAFRO $2005 \mathrm{MEC} / \mathrm{SESu} / \mathrm{SECAD}$ é apoiar as Instituições Públicas de Educação Superior no desenvolvimento de programas e projetos de ensino, pesquisa e extensão que contribuam para a implementação e para o impacto de políticas de ação afirmativa para a população negra, potencializando e ampliando patamares de qualidade das ações propostas, projetando a natureza das mesmas e a missão da universidade pública, e dirigindo recursos para atividades específicas dos programas e projetos. O Edital 2005 objetiva também dotar os NEABs ou grupos correlatos no interior das IES de melhores condições de gestão de suas atividades acadêmicas de ensino, pesquisa e extensão para os fins prioritários enunciados nesse programa. 
Eixos:

Os programas e projetos deverão atender a pelo menos um dos seguintes eixos:

a) Publicação

Incentivo a publicações de obras dirigidas à implementação da Lei 10.639/2003, do Parecer CNE/CP 003/2004 e da Resolução CNE/CP 01/2004 com ênfase em aspectos regionais. Incentivo à produção de material didático-pedagógico.

Apoio a publicações de trabalhos sobre acesso e permanência de afro-brasileiros nas instituições de educação superior.

Apoio à tradução de obras estrangeiras.

b) Formação de professores

Apoio a cursos de especialização, extensão, aperfeiçoamento em conformidade com a implementação da Lei 10.639/2003, do Parecer CNE/CP 003/2004 e da Resolução CNE/CP 01/2004. Os cursos deverão contemplar, prioritariamente, as seguintes áreas: História do negro no Brasil; Literatura afrobrasileira; História da África; História do negro nas Américas.

c) Acesso e Permanência

Apoio a iniciativas institucionais voltadas ao acesso de estudantes negros ao ensino superior.

Apoio a cursos complementares e elaboração de estratégias para o acompanhamento do desempenho acadêmico de estudantes negros cotistas.

Apoio a projetos de pesquisa na área de relações raciais, que contemplem estudantes negros cotistas com bolsas para esse fim. (BRASIL, 2005).

$\mathrm{O}$ edital destinava-se ao apoio a programas ou projetos das instituições, com o valor até $\mathrm{R} \$ 200.000,00$ para os programas, considerados como um conjunto de projetos, e no valor até R\$ 50.000,00 para os projetos, considerados um conjunto de ações. Sendo selecionados até dez propostas de cada categoria 
(programas e/ou projetos), com o valor total do recurso a ser empenhado de $\mathrm{R} \$ 2.500 .000,00$.

Os programas e projetos teriam a duração de dez meses depois da assinatura dos termos de cooperação. $\mathrm{O}$ repasse de recursos seria realizado com uma primeira parcela de $60 \%$ do valor, depois da execução e entrega do relatório da primeira parcela, seria liberada a última, com os $40 \%$ restantes.

O edital n. 02, de 10 de maço de 2006, da SECAD estabelecia exatamente a mesma parceria, eixos e recurso total. Contudo, não havia a distinção entre programas e projetos, e seriam apoiados projetos em uma ou mais linhas de ação com o valor de até $\mathrm{R} \$ 150.000,00$.

Outra inovação do Edital 02/2006 foi informar o calendário dos prazos desde o lançamento do edital e inscrição dos projetos, que contemplava a análise da Comissão Técnica, da Comissão Externa, a divulgação dos resultados e a liberação dos recursos financeiros. Ambos os editais não previam prazos para a interposição de recursos das instituições não aprovadas.

Em 28 de abril de 2008 foi publicada a Resolução n. 14, do Conselho Deliberativo/FNDE/MEC estabelecendo a assistência financeira a projetos no âmbito do Programa Uniafro. A seleção aos projetos foi realizada tendo essa Resolução como instrumento de divulgação.

Em 2009 foi publicado o último edital do Uniafro, o Edital de Convocação n. 18, de 13 de julho de 2009, da SECAD. A Resolução n. 14/2008 e o Edital n. 18/2009 têm as mesmas considerações e objetivos.

Ambos estabelecem considerações sobre a política educacional para a educação das relações étnico-raciais, como:

a) A necessidade de promover ações supletivas e redistributivas, para correção progressiva das disparidades de 
acesso, de permanência e de garantia do padrão de qualidade da Educação Básica.

b) A necessidade de corrigir injustiças, eliminar discriminações e promover a inclusão social e a cidadania para todos no sistema de ensino.

c) A necessidade de respeitar e de valorizar a diversidade étnico-racial e de fortalecer a auto-estima dos alunos e professores.

d) A necessidade de oferta de Educação Básica que atenda ao que dispõe o Artigo 26-A da Lei n 9394/96, o Parecer CNE n. 03/04 e a Resolução 01/2003 que estabelece as Diretrizes Curriculares Nacionais para a Educação das Relações Étnico-Raciais e o Ensino de História e Cultura Afro-Brasileira e Africana.

e) A necessidade de estabelecer critérios e parâmetros para habilitação e apresentação de projetos na temática da Educação para as Relações Etnicorraciais, visando assegurar a implementação dos mesmos, na configuração estabelecida no orçamento de 2009.

f) O Programa de Ações Afirmativas para a População Negra no Ensino Superior - UNIAFRO - visa apoiar e incentivar o fortalecimento e a institucionalização das atividades desenvolvidas pelos Núcleos de Estudos Afro-Brasileiros - NEAB's ou grupos correlatos das Instituições Federais e Estaduais de Educação Superior, contribuindo para a implementação de políticas de ação afirmativa voltadas para a população negra. O Programa busca articular a produção e difusão de conhecimento sobre a temática étnico-racial e o acesso e permanência da população afro-brasileira no ensino superior. (SECAD, 2009).

Essas considerações expressam a posição do Uniafro dentro da esfera da implementação da educação das relações étnico-raciais como programa de promoção da igualdade racial na educação. O programa pretendia possuir um caráter tanto valorativo da cultura negra, na medida em que incentivava a formação e a produção 
de conteúdo que tem a educação das relações étnico-raciais como premissa, quanto redistributivo, por incentivar a adoção de ações afirmativas nas instituições públicas de ensino superior.

Houve mudanças significativas também na descrição dos objetivos. Nos editais de 2005 e 2006 o objetivo era o apoio às ações a serem implementadas pelas instituições dentro dos eixos de atuação e o fortalecimento institucional dos NEAB. Em 2008 e 2009 os objetivos são:
a) Apoiar técnica e financeiramente os projetos que pro- movam a formação continuada de professores e propos- tas de elaboração de materiais didáticos que estejam em devida consonância com a formação de professores, no atendimento do artigo 26-A da Lei de Diretrizes e Base da Educação Nacional.
b) Promover Formação Inicial de graduandos em licen- ciatura e curso de pedagogia em educação das relações étnico-raciais e ensino de história e cultura afro-brasileira e africana, de acordo com o disposto na Resolução CNE/ CP 01/2004 e no Parecer CNE/CP n. 03/2004.
c) Fomentar projetos de Elaboração de Material Didático específico para uso professores e alunos da Educação Bá- sica, sobre Educação das relações étnico-raciais e história e cultura afro-brasileira e africana que atenda ao disposto na Resolução CNE/CP 01/2004 e no Parecer CNE/CP n. 03/2004, visando à implementação do Artigo 26-A da Lei de Diretrizes e Bases da Educação Nacional. (BRASIL, 2008, 2009).

A fim de cumprir tais objetivos, os projetos a serem enviados deveriam apresentar-se de acordo com as seguintes linhas de ação:

a) Projetos de formação inicial que contemplem ações acadêmicas para graduandos de licenciatura e de Pedagogia com a carga horária mínima de $60 \mathrm{~h}$. 
b) Projetos de curso de formação continuada para professores da educação básica do sistema estadual e municipal de ensino, sendo:

Extensão, com carga horária mínima de 80h.

Aperfeiçoamento, com carga horária mínima de 180h.

Especialização, com carga horária de $360 \mathrm{~h}$.

c) Projetos de elaboração de material didático que atenda ao disposto na Resolução CNE/CP n. 01 de 2004, e o anexo II desse Edital. (BRASIL, 2008, 2009).

A Resolução 14/2008 estabelece o valor mínimo das propostas de $\mathrm{R} \$ 100.000,00$ e o máximo de $\mathrm{R} \$ 150.000,00$, sendo os recursos financeiros totais para o apoio aos projetos de $\mathrm{R}$ \$ 2.000.000,00. O prazo máximo para execução dos projetos, depois do recebimento de recursos, era de 18 meses.

O Edital 18/2009 não citava os valores mínimos dos projetos, nem o total do disponibilizado para o edital, nem estabelecia prazos máximos de execução.

Ambos os Editais estabeleceram calendário de 40 dias a partir da publicação para o recebimento das respostas, e 55 dias para a divulgação do resultado final. Não foram previstas datas para a divulgação das inscrições homologadas, ou mesmo para o início do acordo de cooperação, ou o repasse de recursos. A Resolução 14/2008 previa o prazo de 15 dias depois da publicação do resultado final para as instituições encaminharem documentação.

\subsubsection{Execução e resultados}

A partir da análise dos registros no Diário Oficial da União e dos documentos administrativos do Ministério da Educação, foram sistematizadas as informações dos exercícios de 2005 a 2009 do Uniafro. 


\subsubsection{0 exercício de 2005}

O primeiro edital do Uniafro foi publicado no DOU, de 29 de abril de 2005. A Comissão Técnica Multidisciplinar para a seleção e o acompanhamento dos projetos e programas foi instituída pela Portaria Conjunta n. 42, de 1 de junho de 2005.

No dia 8 de julho de 2005 foi publicada no DOU a seguinte lista de aprovados:

Quadro 2 - Instituições Selecionadas/Edital 2005

\begin{tabular}{|c|c|c|}
\hline Instituição & Título do Projeto & Situação \\
\hline $\begin{array}{l}\text { 1. UFBA - } \\
\text { Universidade Federal } \\
\text { da Bahia }\end{array}$ & $\begin{array}{l}\text { Políticas de Inclusão Social na } \\
\text { UFBA: Programa de Ações } \\
\text { Afirmativas }\end{array}$ & $\begin{array}{l}\text { Aprovado } \\
\text { Integralmente }\end{array}$ \\
\hline $\begin{array}{l}\text { 2. UFF - Universidade } \\
\text { Federal Fluminense }\end{array}$ & $\begin{array}{l}\text { Penesb - Educação sobre o Negro na } \\
\text { Sociedade Brasileira }\end{array}$ & $\begin{array}{l}\text { Aprovado } \\
\text { Integralmente }\end{array}$ \\
\hline $\begin{array}{l}\text { 3. UFG - Universidade } \\
\text { Federal de Goiás }\end{array}$ & Uniafro & $\begin{array}{l}\text { Aprovado } \\
\text { Parcialmente }\end{array}$ \\
\hline $\begin{array}{l}\text { 4. UFMA - } \\
\text { Universidade Federal } \\
\text { de Maranhão }\end{array}$ & $\begin{array}{l}\text { Mapeamento étnico-racial e } \\
\text { implementação de um Programa } \\
\text { de ações afirmativas para } \\
\text { afrodescendentes }\end{array}$ & $\begin{array}{l}\text { Aprovado } \\
\text { Parcialmente }\end{array}$ \\
\hline $\begin{array}{l}\text { 5. UFMG - } \\
\text { Universidade Federal } \\
\text { de Minas Gerais }\end{array}$ & $\begin{array}{l}\text { Percursos e horizontes de } \\
\text { formação - ações afirmativas para } \\
\text { universitários negros }\end{array}$ & $\begin{array}{l}\text { Aprovado } \\
\text { Integralmente }\end{array}$ \\
\hline $\begin{array}{l}\text { 6. UFMT - } \\
\text { Universidade Federal } \\
\text { do Mato Grosso }\end{array}$ & $\begin{array}{l}\text { Trabalhando as diferenças na } \\
\text { educação em Mato Grosso }\end{array}$ & $\begin{array}{l}\text { Aprovado } \\
\text { Parcialmente }\end{array}$ \\
\hline $\begin{array}{l}\text { 7. UFPR - } \\
\text { Universidade Federal } \\
\text { do Paraná }\end{array}$ & $\begin{array}{l}\text { Representações do negro e seus } \\
\text { impactos no processo educacional } \\
\text { no Paraná }\end{array}$ & $\begin{array}{l}\text { Aprovado } \\
\text { Integralmente }\end{array}$ \\
\hline $\begin{array}{l}\text { 8. UFSCAR - } \\
\text { Universidade Federal } \\
\text { de São Carlos }\end{array}$ & $\begin{array}{l}\text { Curso de especialização "Estudos } \\
\text { culturais Afro-brasileiros e } \\
\text { Africanidades" }\end{array}$ & $\begin{array}{l}\text { Aprovado } \\
\text { Parcialmente }\end{array}$ \\
\hline $\begin{array}{l}\text { 9. UFT - Universidade } \\
\text { Federal de Tocantins }\end{array}$ & $\begin{array}{l}\text { Curso de Especialização em História } \\
\text { da África, da Cultura Negra e do } \\
\text { Negro no Brasil }\end{array}$ & $\begin{array}{l}\text { Aprovado } \\
\text { Parcialmente }\end{array}$ \\
\hline
\end{tabular}




\begin{tabular}{|l|l|l|}
\hline Instituição & Título do Projeto & Situação \\
\hline $\begin{array}{l}\text { 10. UDESC - } \\
\text { Universidade do Estado } \\
\text { de Santa Catarina }\end{array}$ & Diversidade étnica na educação & $\begin{array}{l}\text { Aprovado } \\
\text { Parcialmente }\end{array}$ \\
\hline $\begin{array}{l}\text { 11. UEL - Universidade } \\
\text { Estadual de Londrina }\end{array}$ & $\begin{array}{l}\text { Programa de ações afirmativas para a } \\
\text { população negra de Londrina }\end{array}$ & $\begin{array}{l}\text { Aprovado } \\
\text { Parcialmente }\end{array}$ \\
\hline $\begin{array}{l}\text { 12. UERJ - } \\
\text { Universidade Estadual } \\
\text { do Rio de Janeiro }\end{array}$ & $\begin{array}{l}\text { Formação e Permanência de Afro- } \\
\text { Brasileiros da UERJ }\end{array}$ & $\begin{array}{l}\text { Aprovado } \\
\text { Parcialmente }\end{array}$ \\
\hline $\begin{array}{l}\text { 13. UESC - } \\
\text { Universidade Estadual } \\
\text { de Santa Cruz }\end{array}$ & $\begin{array}{l}\text { BANTU-IÊ - África-Brasil e } \\
\text { educação das relações étnico-raciais }\end{array}$ & $\begin{array}{l}\text { Aprovado } \\
\text { Parcialmente }\end{array}$ \\
\hline $\begin{array}{l}\text { 14. UNEB - } \\
\text { Universidade Estadual } \\
\text { da Bahia }\end{array}$ & $\begin{array}{l}\text { AFROUNEB - Ações afirmativas, } \\
\text { igualdade racial e compromisso } \\
\text { social na construção de uma nova } \\
\text { cultura }\end{array}$ & $\begin{array}{l}\text { Aprovado } \\
\text { Integralmente }\end{array}$ \\
\hline $\begin{array}{l}\text { 15. UNEMAT - } \\
\text { Universidade Estadual } \\
\text { do Mato Grosso }\end{array}$ & $\begin{array}{l}\text { Programa étnico-racial de acesso, } \\
\text { permanência e qualificação }\end{array}$ & $\begin{array}{l}\text { Aprovado } \\
\text { Parcialmente }\end{array}$ \\
\hline $\begin{array}{l}\text { 16. UNESP - } \\
\text { Universidade Estadual } \\
\text { de São Paulo }\end{array}$ & $\begin{array}{l}\text { Ações afirmativas para a população } \\
\text { negra do núcleo negro da UNESP } \\
\text { para pesquisa e extensão }\end{array}$ & $\begin{array}{l}\text { Aprovado } \\
\text { Integralmente }\end{array}$ \\
\hline $\begin{array}{l}\text { 17. UNIOESTE - USP - Universidade } \\
\text { de São Paulo } \\
\text { do Oeste do Paraná }\end{array}$ & $\begin{array}{l}\text { Pró-Afro - pesquisa, releitura e } \\
\text { formação } \\
\text { Africanos/USP na formação, } \\
\text { produção e transformação social no } \\
\text { espírito da Lei 10.639/2003 }\end{array}$ & $\begin{array}{l}\text { Aprovado } \\
\text { Integralmente }\end{array}$ \\
\hline Parcialmente \\
\hline Fonado
\end{tabular}

Fonte: Adaptado de SECAD (2005, p. 31)

Foi informado também que as instituições públicas de ensino superior aprovadas receberiam ofícios do MEC para adequações orçamentárias e o início da implementação dos projetos.

Contudo, os recursos financeiros para execução dos projetos começaram a ser repassados pelo MEC no dia $1^{\circ}$ de dezembro de 2005 para as seguintes instituições: 
Quadro3 - Instituições Selecionadas que Receberam Recursos em 01/12/2005 ${ }^{29}$

\begin{tabular}{|c|c|c|}
\hline Instituição & Título $^{29}$ & $\begin{array}{l}\text { Recursos } \\
\text { financeiros }\end{array}$ \\
\hline $\begin{array}{l}\text { Universidade Federal do } \\
\text { Paraná - UFPR }\end{array}$ & $\begin{array}{l}\text { Representações do negro no } \\
\text { estado do Paraná e suas relações } \\
\text { com as políticas afirmativas } \\
\text { implantadas }\end{array}$ & $\mathrm{R} \$ 50.000,00$ \\
\hline $\begin{array}{l}\text { Universidade Federal } \\
\text { Fluminense - UFF }\end{array}$ & $\begin{array}{l}\text { Programa de Educação sobre o } \\
\text { Negro na Sociedade Brasileira }\end{array}$ & $\mathrm{R} \$ 200.000,00$ \\
\hline $\begin{array}{l}\text { Universidade Federal da } \\
\text { Bahia - UFBA }\end{array}$ & $\begin{array}{l}\text { Desenvolvimento do programa } \\
\text { de ações afirmativas da UFBA, } \\
\text { através de ações pelo Centro de } \\
\text { Estudos Afro-Orientais, visando } \\
\text { à permanência de estudantes } \\
\text { negros oriundos de escola } \\
\text { pública; publicações de textos e } \\
\text { livros africanos, e formação de } \\
\text { professores nas áreas de História, } \\
\text { Cultura e Literatura Afro- } \\
\text { Brasileira }\end{array}$ & $\mathrm{R} \$ 200.000,00$ \\
\hline $\begin{array}{l}\text { Fundação Universidade } \\
\text { Federal de Tocantins - UFT }\end{array}$ & $\begin{array}{l}\text { Apoio à publicação de vídeo } \\
\text { Comunidade Negra Rural } \\
\text { dos Kalunga; Comunidade } \\
\text { Negra Rural do Mumbucas e } \\
\text { Comunidade Negra Rural da } \\
\text { Aroeira; publicação de uma } \\
\text { coletânea bibliográfica referente } \\
\text { aos trabalhos produzidos pelos } \\
\text { membros do NEAB, TO e a } \\
\text { iniciação científica de alunos da } \\
\text { Graduação }\end{array}$ & $\begin{array}{l}\mathrm{R} \$ 197.400,00 \\
\mathrm{R} \$ 50.000,00\end{array}$ \\
\hline $\begin{array}{l}\text { Fundação Universidade } \\
\text { Federal de São Carlos - } \\
\text { FUFSCar }\end{array}$ & $\begin{array}{l}\text { Programa de Extensão } \\
\text { Universitária: Curso de } \\
\text { especialização "Estudos culturais } \\
\text { Afro-brasileiros e Africanidades" }\end{array}$ & $50.000,00$ \\
\hline
\end{tabular}

${ }^{29}$ Alguns títulos de projetos mudaram do período da aprovação até o repasse dos recursos financeiros. 


\begin{tabular}{|l|l|l|}
\hline Instituição & Título $^{29}$ & $\begin{array}{l}\text { Recursos } \\
\text { financeiros }\end{array}$ \\
\hline $\begin{array}{l}\text { Universidade Federal do } \\
\text { Maranhão - UFMA }\end{array}$ & $\begin{array}{l}\text { Mapeamento Étnico Racial } \\
\text { e Implementação de um } \\
\text { Programa de Ações Afirmativas } \\
\text { para Afrodescendentes na } \\
\text { Universidade Federal do } \\
\text { Maranhão }\end{array}$ & $\mathrm{R} \$ 50.000,00$ \\
\hline Total & 6 projetos & $\mathrm{R} \$ 797.400,00$ \\
\hline
\end{tabular}

Fonte: Adaptado de SESu (2005a, p. 13)

Em 9 de dezembro de 2005, foram publicados no DOU os seguintes repasses financeiros:

Quadro 4 - Instituições Selecionadas que Receberam Recursos em 09/12/2005

\begin{tabular}{|l|l|l|}
\hline Instituição & Título & $\begin{array}{l}\text { Recursos } \\
\text { financeiros }\end{array}$ \\
\hline $\begin{array}{l}\text { Fundação Universidade } \\
\text { Federal de Mato Grosso - } \\
\text { FUFMT }\end{array}$ & $\begin{array}{l}\text { Apoio financeiro destinado a } \\
\text { estabelecer ações no âmbito da } \\
\text { Universidade e da Educação } \\
\text { Básica que contribuam a erradicar } \\
\text { as desigualdades raciais no Estado } \\
\text { do Mato Grosso }\end{array}$ & R\$ 50.000,00 \\
\hline $\begin{array}{l}\text { Universidade Federal de } \\
\text { Minas Gerais - UFMG }\end{array}$ & $\begin{array}{l}\text { Percursos e Horizontes de } \\
\text { Formação: Ações afirmativas para } \\
\text { universitários negros na UFMG } \\
- \text { Uma proposta do Programa } \\
\text { Ações Afirmativas na UFMG }\end{array}$ & R \$200.000,00 \\
\hline $\begin{array}{l}\text { Universidade Federal de } \\
\text { Goiás - UFG }\end{array}$ & $\begin{array}{l}\text { Apoio financeiro destinado ao } \\
\text { Projeto “Passagem do Meio: } \\
\text { Qualificação Para Pesquisa } \\
\text { Étnico-Racial” }\end{array}$ & R\$ 49.994,00 \\
\hline Total & 3 projetos & $299.994,00$ \\
\hline
\end{tabular}

Fonte: Adaptado de SESu (2005b, p. 25)

Ou seja, das 18 instituições aprovadas, somente nove firmaram o Acordo de Cooperação e receberam os recursos do MEC 
para a execução de seus projetos em 2005, tendo essas informações publicadas no DOU.

A fim de sistematizar as informações dos Relatórios Técnicos sobre os projetos, foi organizado o Quadro 5.

Quadro 5 - Resumo das Informações dos Convênios/2005

\begin{tabular}{|c|c|c|c|}
\hline $\begin{array}{l}\text { Título/ } \\
\text { Instituição }\end{array}$ & Objetivo & Conclusão & Ações realizadas \\
\hline $\begin{array}{l}\text { 1. Universidade } \\
\text { Estadual de São } \\
\text { Paulo }\end{array}$ & $\begin{array}{l}\text { Apoiar a permanência } \\
\text { e aprimoramento } \\
\text { técnico, científico } \\
\text { e acadêmico } \\
\text { de graduandos } \\
\text { afro-brasileiros; } \\
\text { promover ingresso } \\
\text { de alunos negros } \\
\text { concluintes do Ensino } \\
\text { Médio na escola } \\
\text { às Universidades } \\
\text { Públicas do Estado } \\
\text { de São Paulo; realizar } \\
\text { levantamento } \\
\text { de dados sobre a } \\
\text { população negra do } \\
\text { interior do estado de } \\
\text { São Paulo }\end{array}$ & 2008 & $\begin{array}{l}\text { Realização de } \\
\text { cursos à distância } \\
\text { para formação de } \\
\text { professores, formação } \\
\text { de banco de dados e } \\
\text { revistas acadêmicas } \\
\text { na temática étnico- } \\
\text { racial, parceria da } \\
\text { Universidade com a } \\
\text { Secretaria de Saúde } \\
\text { para a realização de } \\
\text { cartilha sobre a Saúde } \\
\text { da População Negra }\end{array}$ \\
\hline $\begin{array}{l}\text { 2. Universidade } \\
\text { Estadual do Rio } \\
\text { de Janeiro }\end{array}$ & $\begin{array}{l}\text { Apoiar as ações } \\
\text { de implantação e } \\
\text { implementação } \\
\text { do Programa } \\
\text { de Formação e } \\
\text { Permanência de Afro- } \\
\text { Brasileiros da UERJ }\end{array}$ & 2007 & $\begin{array}{l}\text { Fornecimento de } \\
\text { auxílio a estudantes de } \\
\text { graduação e de pós- } \\
\text { graduação; realização } \\
\text { de seminários sobre } \\
\text { educação das relações } \\
\text { étnico-raciais; } \\
\text { curso de extensão } \\
\text { sobre educação das } \\
\text { relações étnico- } \\
\text { raciais e publicação } \\
\text { de materiais de } \\
\text { orientação a } \\
\text { professores sobre } \\
\text { educação das relações } \\
\text { étnico-raciais }\end{array}$ \\
\hline
\end{tabular}




\begin{tabular}{|c|c|c|c|}
\hline $\begin{array}{l}\text { Título/ } \\
\text { Instituição }\end{array}$ & Objetivo & Conclusão & Ações realizadas \\
\hline $\begin{array}{l}\text { 3. Universidade } \\
\text { Estadual de } \\
\text { Londrina }\end{array}$ & $\begin{array}{l}\text { Apoiar as ações } \\
\text { de implantação e } \\
\text { implementação } \\
\text { do Programa de } \\
\text { Ações Afirmativas } \\
\text { para a População } \\
\text { Negra de Londrina, } \\
\text { desenvolvidas pelo } \\
\text { Núcleo de Estudos } \\
\text { Afro Asiáticos - } \\
\text { NEAA. A formação } \\
\text { de professores, } \\
\text { a publicação de } \\
\text { material e bolsas } \\
\text { de permanência de } \\
\text { estudantes negros }\end{array}$ & 2008 & $\begin{array}{l}\text { Realização de } \\
\text { capacitação de } \\
\text { professores para } \\
\text { trabalhar com a Lei } \\
\text { 10.639/2003 e apoio a } \\
\text { acesso e permanência } \\
\text { de estudantes } \\
\text { afro-brasileiros na } \\
\text { universidade }\end{array}$ \\
\hline $\begin{array}{l}\text { 4. Universidade } \\
\text { Estadual de Santa } \\
\text { Cruz }\end{array}$ & $\begin{array}{l}\text { Realizar Pesquisa } \\
\text { de Amostragem } \\
\text { Étnico-Racial; Curso } \\
\text { de Especialização } \\
\text { em Educação e } \\
\text { Relações Étnico- } \\
\text { Raciais; Seminário } \\
\text { de avaliação do } \\
\text { Programa BANTU-IÊ }\end{array}$ & 2008 & $\begin{array}{l}\text { Descrita como uma } \\
\text { das experiências mais } \\
\text { exitosas de ação por } \\
\text { articular os } 3 \text { eixos } \\
\text { de ação e ter sido } \\
\text { executa integralmente. } \\
\text { Segundo o relatório } \\
\text { "Como resultado } \\
\text { direto das ações } \\
\text { dos envolvidos no } \\
\text { projeto (estudantes, } \\
\text { professores } \\
\text { de graduação, } \\
\text { participantes das } \\
\text { ações de formação), } \\
\text { foi aprovada a } \\
\text { reserva de vagas } \\
\text { para estudantes } \\
\text { negros na UESC e } \\
\text { foi criada a linha de } \\
\text { pesquisa "Educação e } \\
\text { Diversidade Cultural" } \\
\text { no Departamento de } \\
\text { Ciências da Educação } \\
\text { da Universidade." }\end{array}$ \\
\hline
\end{tabular}




\begin{tabular}{|c|c|c|c|}
\hline $\begin{array}{l}\text { Título/ } \\
\text { Instituição }\end{array}$ & Objetivo & Conclusão & Ações realizadas \\
\hline $\begin{array}{l}\text { 5. Universidade } \\
\text { do Estado de } \\
\text { Mato Grosso }\end{array}$ & $\begin{array}{l}\text { Qualificar professores } \\
\text { do município de } \\
\text { Cáceres/MT para a } \\
\text { implementação da } \\
\text { 10.639/2003 }\end{array}$ & 2007 & $\begin{array}{l}\text { Foram formados } 19 \\
\text { professores no nível } \\
\text { especialização, com } \\
460 \text { horas aula }\end{array}$ \\
\hline $\begin{array}{l}\text { 6. Universidade } \\
\text { do Estado da } \\
\text { Bahia }\end{array}$ & $\begin{array}{l}\text { Apoio ao Projeto } \\
\text { AFROUNEB: Ações } \\
\text { Afirmativas, igualdade } \\
\text { racial e compromisso } \\
\text { social na construção } \\
\text { de uma nova } \\
\text { cultura universitária } \\
\text { (Publicação de } \\
\text { distribuição de } \\
\text { material; bolsas de } \\
\text { estudo e iniciação } \\
\text { cientifica a alunos } \\
\text { negros. Formação de } \\
\text { docentes) }\end{array}$ & 2008 & $\begin{array}{l}\text { Foram implantados } \\
05 \text { (cinco) Núcleos de } \\
\text { estudos sobre História } \\
\text { e Cultura Afro- } \\
\text { Brasileira e Africana } \\
\text { na UNEB, abrangendo } \\
\text { as seguintes } \\
\text { licenciaturas: } \\
\text { Biologia, Matemática, } \\
\text { Pedagogia, Geografia, } \\
\text { História e Letras }\end{array}$ \\
\hline $\begin{array}{l}\text { 7. Universidade } \\
\text { Estadual do Oeste } \\
\text { do Paraná }\end{array}$ & $\begin{array}{l}\text { Executar o Projeto } \\
\text { "Pró-Afro: Pesquisa, } \\
\text { releitura e formação", } \\
\text { o qual pretende fazer } \\
\text { pesquisa acerca da } \\
\text { inserção de alunos } \\
\text { afro-descendentes } \\
\text { na escola e capacitar } \\
\text { alunos da rede } \\
\text { pública do município } \\
\text { de Francisco Beltrão } \\
\text { e professores da rede } \\
\text { pública }\end{array}$ & 2008 & $\begin{array}{l}\text { Realização de curso de } \\
\text { formação continuada } \\
\text { presencial para } 44 \\
\text { professores (60h) } \\
\text { intitulado "Formação } \\
\text { de professores e } \\
\text { diversidade étnico- } \\
\text { racial", e uma pesquisa } \\
\text { quantitativa sobre a } \\
\text { inserção de alunos } \\
\text { afro-brasileiros } \\
\text { na escola pública, } \\
\text { "Afrodescendentes na } \\
\text { escola pública" }\end{array}$ \\
\hline
\end{tabular}




\begin{tabular}{|c|c|c|c|}
\hline $\begin{array}{l}\text { Título/ } \\
\text { Instituição }\end{array}$ & Objetivo & Conclusão & Ações realizadas \\
\hline $\begin{array}{l}\text { 8. Universidade } \\
\text { do Estado de } \\
\text { Santa Catarina }\end{array}$ & $\begin{array}{l}\text { Fornecer apoio } \\
\text { técnico e financeiro } \\
\text { à execução } \\
\text { do Programa } \\
\text { "Diversidade Étnica } \\
\text { na Educação" }\end{array}$ & 2008 & $\begin{array}{l}\text { Foi realizado } \\
\text { processo de formação } \\
\text { com educadores e } \\
\text { educadoras nas redes } \\
\text { de ensino formal e } \\
\text { informal, de modo } \\
\text { a redimensionar } \\
\text { práticas educativas } \\
\text { fundamentando-as } \\
\text { em uma proposta } \\
\text { multicultural para a } \\
\text { educação das relações } \\
\text { étnico-raciais }\end{array}$ \\
\hline $\begin{array}{l}\text { 9. Universidade } \\
\text { do Estado da } \\
\text { Bahia }\end{array}$ & $\begin{array}{l}\text { Implantação e } \\
\text { Implementação do } \\
\text { Projeto AFROUNEB: } \\
\text { Ações Afirmativas, } \\
\text { igualdade racial e } \\
\text { compromisso social } \\
\text { na construção de } \\
\text { uma nova cultura } \\
\text { universitária }\end{array}$ & 2008 & $\begin{array}{l}\text { Publicação de } \\
\text { material didático e } \\
\text { distribuição às escolas } \\
\text { da rede pública de } \\
\text { ensino fundamental; } \\
\text { fornecimento de } \\
\text { bolsas de estudo a } \\
35 \text { estudantes afro- } \\
\text { brasileiros cotistas e } \\
\text { realização da inserção } \\
\text { destes estudantes em } \\
\text { projetos científicos } \\
\text { sobre história e } \\
\text { cultura afro-brasileira } \\
\text { e africana; realização } \\
\text { de formação de } 250 \\
\text { professores do Ensino } \\
\text { Fundamental em } \\
\text { história e cultura afro- } \\
\text { brasileira e africana; e } \\
\text { avaliação do sistema } \\
\text { de cotas }\end{array}$ \\
\hline
\end{tabular}

Fonte: Elaborado pela autora desta obra 


\subsubsection{Exercício de 2006}

Como exposto anteriormente, no dia 10 de março de 2006 foi publicado no DOU o $2^{\circ}$ Edital do Uniafro. A Comissão Técnica Multidisciplinar para a seleção dos projetos foi instituída pela Portaria Conjunto n. 27, de 18 de maio de 2006.

No dia 2 de junho de 2006, foi publicada a seguinte lista de aprovados:

Quadro 6 - Instituições Selecionadas/Edital 2006

\begin{tabular}{|c|c|c|}
\hline Instituição & Título & Situação \\
\hline $\begin{array}{l}\text { 1. Universidade } \\
\text { Federal do Sergipe }\end{array}$ & $\begin{array}{l}\text { Curso de Aperfeiçoamento em } \\
\text { Estudos africanos, história e cultura } \\
\text { afro-brasileira }\end{array}$ & $\begin{array}{l}\text { Aprovado } \\
\text { Integralmente }\end{array}$ \\
\hline $\begin{array}{l}\text { 2. Universidade } \\
\text { Federal do Rio de } \\
\text { Janeiro }\end{array}$ & $\begin{array}{l}\text { Pesquisa e extensão sobre } \\
\text { desigualdades raciais no Brasil: } \\
\text { construção de séries históricas, } \\
\text { análises e tendências dos indicadores } \\
\text { sociais e formação teórica de } \\
\text { lideranças da sociedade civil }\end{array}$ & $\begin{array}{l}\text { Aprovado } \\
\text { Parcialmente }\end{array}$ \\
\hline $\begin{array}{l}\text { 3. Universidade } \\
\text { Federal do Piauí }\end{array}$ & $\begin{array}{l}\text { Políticas de Ação Afirmativa para } \\
\text { Afrodescendentes na Universidade } \\
\text { Federal do Piauí }\end{array}$ & $\begin{array}{l}\text { Aprovado } \\
\text { Parcialmente }\end{array}$ \\
\hline $\begin{array}{l}\text { 4. Universidade } \\
\text { Federal do Paraná }\end{array}$ & $\begin{array}{l}\text { Desigualdades raciais e políticas } \\
\text { afirmativas no estado do Paraná }\end{array}$ & $\begin{array}{l}\text { Aprovado } \\
\text { Integralmente }\end{array}$ \\
\hline $\begin{array}{l}\text { 5. Universidade } \\
\text { Federal do Mato } \\
\text { Grosso }\end{array}$ & $\begin{array}{l}\text { Trabalhando as Diferenças na } \\
\text { Educação em Mato Grosso }\end{array}$ & $\begin{array}{l}\text { Aprovado } \\
\text { Integralmente }\end{array}$ \\
\hline $\begin{array}{l}\text { 6. Universidade } \\
\text { Federal de Uberlândia }\end{array}$ & $\begin{array}{l}\text { Projeto de apoio ao núcleo de } \\
\text { estudos afro-brasileiros da UFU }\end{array}$ & $\begin{array}{l}\text { Aprovado } \\
\text { Parcialmente }\end{array}$ \\
\hline $\begin{array}{l}\text { 7. Universidade } \\
\text { Federal de Minas } \\
\text { Gerais }\end{array}$ & $\begin{array}{l}\text { Novos percursos e novos horizontes } \\
\text { de formação: a continuidade das } \\
\text { ações afirmativas para universitários } \\
\text { negros na UFMG }\end{array}$ & $\begin{array}{l}\text { Aprovado } \\
\text { Integralmente }\end{array}$ \\
\hline $\begin{array}{l}\text { 8. Universidade } \\
\text { Federal de São Carlos }\end{array}$ & $\begin{array}{l}\text { Programa de Pesquisa e Formação } \\
\text { em Estudos Culturais Afro- } \\
\text { Brasileiros e Africanidades }\end{array}$ & $\begin{array}{l}\text { Aprovado } \\
\text { Parcialmente }\end{array}$ \\
\hline
\end{tabular}




\begin{tabular}{|c|c|c|}
\hline Instituição & Título & Situação \\
\hline $\begin{array}{l}\text { 9. Universidade } \\
\text { Federal de Alagoas }\end{array}$ & $\begin{array}{l}\text { Programa de Ações Afirmativas da } \\
\text { UFAL }\end{array}$ & $\begin{array}{l}\text { Aprovado } \\
\text { Parcialmente }\end{array}$ \\
\hline $\begin{array}{l}\text { 10. Universidade } \\
\text { Federal da Bahia }\end{array}$ & $\begin{array}{l}\text { Programa Preparatório para a } \\
\text { Promoção da Igualdade Étnico-racial } \\
\text { na Educação }\end{array}$ & $\begin{array}{l}\text { Aprovado } \\
\text { Integralmente }\end{array}$ \\
\hline $\begin{array}{l}\text { 11. Universidade } \\
\text { Estadual de Goiás }\end{array}$ & $\begin{array}{l}\text { Estudos Africanos e Afro- } \\
\text { Americanos - Qualificação e } \\
\text { Capacitação Docente para Formação } \\
\text { de Multiplicadores }\end{array}$ & $\begin{array}{l}\text { Aprovado } \\
\text { Pacialmente }\end{array}$ \\
\hline $\begin{array}{l}\text { 12. Universidade } \\
\text { Estadual de Santa Cruz }\end{array}$ & $\begin{array}{l}\text { Programa Bantu-Iê: África-Brasil e } \\
\text { educação das relações étnico-raciais }\end{array}$ & $\begin{array}{l}\text { Aprovado } \\
\text { Parcialmente }\end{array}$ \\
\hline $\begin{array}{l}\text { 13. Universidade } \\
\text { Estadual de Londrina }\end{array}$ & $\begin{array}{l}\text { Programa de ações afirmativas para } \\
\text { a população negra de Londrina } \\
\text { desenvolvidas pelo NEAA/UEL }\end{array}$ & $\begin{array}{l}\text { Aprovado } \\
\text { Parcialmente }\end{array}$ \\
\hline $\begin{array}{l}\text { 14. Universidade } \\
\text { Estadual do Sudoeste } \\
\text { da Bahia }\end{array}$ & $\begin{array}{l}\text { Educação e Relações Étnicas com } \\
\text { Ênfase em Culturas Afro-Brasileiras }\end{array}$ & $\begin{array}{l}\text { Aprovado } \\
\text { Parcialmente }\end{array}$ \\
\hline $\begin{array}{l}\text { 15. Universidade do } \\
\text { Estado do Rio Grande } \\
\text { do Norte }\end{array}$ & $\begin{array}{l}\text { EQUIDADE SOCIAL E } \\
\text { IGUALDADE RACIAL: horizontes } \\
\text { de uma educação democrática e } \\
\text { cidadã }\end{array}$ & $\begin{array}{l}\text { Aprovado } \\
\text { Parcialmente }\end{array}$ \\
\hline $\begin{array}{l}\text { 16. Universidade do } \\
\text { Estado do Rio de } \\
\text { Janeiro }\end{array}$ & $\begin{array}{l}\text { II Programa de Formação e } \\
\text { Permanência de Afro-Brasileiros da } \\
\text { UERJ }\end{array}$ & $\begin{array}{l}\text { Aprovado } \\
\text { Parcialmente }\end{array}$ \\
\hline $\begin{array}{l}\text { 17. Universidade } \\
\text { do Estado de Santa } \\
\text { Catarina }\end{array}$ & $\begin{array}{l}\text { Programa Diversidade Étnica na } \\
\text { Educação - PDEE/UNIAFRO }\end{array}$ & $\begin{array}{l}\text { Aprovado } \\
\text { Parcialmente }\end{array}$ \\
\hline $\begin{array}{l}\text { 18. Universidade } \\
\text { do Estado de Minas } \\
\text { Gerais }\end{array}$ & $\begin{array}{l}\text { Capacitação em História Afro- } \\
\text { Brasileira e Africana de Professores } \\
\text { da Educação Básica da Região } \\
\text { Metropolitana de Belo Horizonte }\end{array}$ & $\begin{array}{l}\text { Aprovado } \\
\text { Parcialmente }\end{array}$ \\
\hline $\begin{array}{l}\text { 19. Universidade do } \\
\text { Estado da Bahia }\end{array}$ & $\begin{array}{l}\text { AFROUNEB II: ações afirmativas, } \\
\text { igualdade racial e compromisso social } \\
\text { na construção de uma nova cultura } \\
\text { universitária }\end{array}$ & $\begin{array}{l}\text { Aprovado } \\
\text { Integralmente }\end{array}$ \\
\hline
\end{tabular}




\begin{tabular}{|l|l|l|}
\hline Instituição & Título & Situação \\
\hline $\begin{array}{l}\text { 20. Universidade de } \\
\text { São Paulo }\end{array}$ & $\begin{array}{l}\text { Percepções da diferença. Produção } \\
\text { de material de consulta e apoio } \\
\text { para a educação das relações raciais } \\
\text { e implementação da Lei 10.639/2003 }\end{array}$ & $\begin{array}{l}\text { Aprovado } \\
\text { Integralmente }\end{array}$ \\
\hline $\begin{array}{l}\text { 21. Universidade de } \\
\text { Brasília }\end{array}$ & $\begin{array}{l}\text { Curso de Especialização em Estudos } \\
\text { Afro-brasileiros no contexto da Lei } \\
\text { Federal 10.639/2003 com apoio a } \\
\text { estudantes cotistas de baixa renda }\end{array}$ & $\begin{array}{l}\text { Aprovado } \\
\text { Parcialmente }\end{array}$ \\
\hline $\begin{array}{l}\text { 22. Centro Federal de } \\
\text { Educação Tecnológica } \\
\text { do Pará }\end{array}$ & $\begin{array}{l}\text { Resgate e mapeamento da exclusão } \\
\text { de afro descendentes no ensino } \\
\text { superior nos CEFET da região norte } \\
\text { e nordeste - implicações nas políticas } \\
\text { Públicas }\end{array}$ & $\begin{array}{l}\text { Aprovado } \\
\text { Parcialmente }\end{array}$ \\
\hline
\end{tabular}

Fonte: Adaptado de SECAD (2006, p. 44)

No DOU só há menção a repasses financeiros no dia 20 de novembro de 2006, destinado à UnB, no valor de R $\$ 107.788,10$ para a realização de seminários de avaliação e socialização de experiências do Programa de Formação Superior e Licenciaturas (PROLIND) e do Uniafro. Assim, é possível que o repasse dos demais recursos, via destaque orçamentário, não tenha sido publicado.

A fim de sistematizar as informações dos Relatórios Técnicos sobre os projetos, foi organizado o Quadro 7.

Quadro 7 - Resumo das Informações dos Convênios de 2006

\begin{tabular}{|c|c|c|c|}
\hline Título/Instituição & Objetivo & Conclusão & Ações realizadas \\
\hline $\begin{array}{l}\text { 1. Universidade do } \\
\text { Estado de Santa } \\
\text { Catarina }\end{array}$ & $\begin{array}{l}\text { Programa } \\
\text { Diversidade } \\
\text { Étnica na } \\
\text { Educação } \\
\text { - PDEE/ } \\
\text { UNIAFRO }\end{array}$ & 2010 & $\begin{array}{l}\text { Apoio as ações de } \\
\text { Programa de pesquisa e } \\
\text { Extensão universitária, } \\
\text { voltado para a criação } \\
\text { e consolidação de } \\
\text { Programas Municipais } \\
\text { e Estadual de } \\
\text { diversidade Étnica na } \\
\text { Educação, com vista a } \\
\text { implementação da Lei } \\
\text { Federal 10.639/2003. } \\
\text { R\$ } 114.325,00\end{array}$ \\
\hline
\end{tabular}




\begin{tabular}{|c|c|c|c|}
\hline Título/Instituiçãao & Objetivo & Conclusão & Ações realizadas \\
\hline $\begin{array}{l}\text { 2. Universidade } \\
\text { Estadual de Londrina }\end{array}$ & $\begin{array}{l}\text { Programa } \\
\text { de ações } \\
\text { afirmativas para a } \\
\text { população negra } \\
\text { de Londrina } \\
\text { desenvolvidas } \\
\text { pelo NEAA/ } \\
\text { UEL }\end{array}$ & & $\begin{array}{l}\text { Publicação, capacitação } \\
\text { de docentes e } \\
\text { fornecimento de bolsas } \\
\text { de permanência }\end{array}$ \\
\hline $\begin{array}{l}\text { 3. Universidade de } \\
\text { São Paulo }\end{array}$ & $\begin{array}{l}\text { Percepções } \\
\text { da diferença. } \\
\text { Produção de } \\
\text { material de } \\
\text { consulta e } \\
\text { apoio para a } \\
\text { educação das } \\
\text { relações raciais e } \\
\text { implementação } \\
\text { da Lei } \\
\text { 10.639/2003 }\end{array}$ & 2007 & $\begin{array}{l}\text { Criação do site } \\
\text { "NEINB responde" e } \\
\text { produção da coleção } \\
\text { "Percepções da } \\
\text { diferença. Negros e } \\
\text { brancos na escola" }\end{array}$ \\
\hline $\begin{array}{l}\text { 4. Universidade } \\
\text { Federal de Sergipe }\end{array}$ & $\begin{array}{l}\text { Curso de } \\
\text { Aperfeiçoamento } \\
\text { em Estudos } \\
\text { africanos, } \\
\text { história e cultura } \\
\text { afro-brasileira }\end{array}$ & & $\begin{array}{l}\text { Produzir, editar } \\
\text { e publicar } 1000 \\
\text { exemplares de um livro } \\
\text { contendo artigos dos } \\
\text { diferentes atores do } \\
\text { programa UNIAFRO, } \\
\text { produzidos a partir do } \\
\text { curso oferecido. } \\
\text { Certificar } 40 \text { pessoas } \\
\text { em Aracaju e } 40 \text { em } \\
\text { Itabaiana, num de total } \\
80 \text { alunos, em História } \\
\text { Africana e Afro- } \\
\text { brasileira }\end{array}$ \\
\hline
\end{tabular}




\begin{tabular}{|c|c|c|c|}
\hline Título/Instituição & Objetivo & Conclusão & Ações realizadas \\
\hline $\begin{array}{l}\text { 5. Universidade } \\
\text { Federal do Rio de } \\
\text { Janeiro }\end{array}$ & $\begin{array}{l}\text { Pesquisa e } \\
\text { extensão sobre } \\
\text { desigualdades } \\
\text { raciais no Brasil: } \\
\text { construção de } \\
\text { séries históricas, } \\
\text { análise de } \\
\text { tendências dos } \\
\text { indicadores } \\
\text { sociais e } \\
\text { formação teórica } \\
\text { de lideranças da } \\
\text { sociedade civil }\end{array}$ & 2007 & $\begin{array}{l}\text { Publicação* - } \\
\text { Relatório Anual das } \\
\text { Desigualdades Raciais } \\
\text { no Brasil. Realização de } \\
\text { Oficinas de formação } \\
\text { de pesquisadores e } \\
\text { ativistas na leitura } \\
\text { e interpretação } \\
\text { de indicadores } \\
\text { demográficos e } \\
\text { socioecnômicos, com } \\
\text { especial ênfase para } \\
\text { o tema das relações } \\
\text { raciais }\end{array}$ \\
\hline $\begin{array}{l}\text { 6. Universidade } \\
\text { Federal de Minas } \\
\text { Gerais }\end{array}$ & $\begin{array}{l}\text { Novos Percursos } \\
\text { e Novos } \\
\text { Horizontes de } \\
\text { Formação: A } \\
\text { continuidade } \\
\text { das Ações } \\
\text { Afirmativas para } \\
\text { universitários } \\
\text { negros na } \\
\text { UFMG }\end{array}$ & & $\begin{array}{l}\text { Realização do II Curso } \\
\text { de Aperfeiçoamento } \\
\text { em História da África } \\
\text { e das Culturas Afro- } \\
\text { brasileiras. } \\
\text { Meta prevista: } 40 \\
\text { professores, registro } \\
\text { e publicação das } \\
\text { experiências do curso }\end{array}$ \\
\hline $\begin{array}{l}\text { 7. Universidade } \\
\text { Federal do Piauí }\end{array}$ & & 2007 & $\begin{array}{l}\text { Formar pesquisadores } \\
\text { e profissionais } \\
\text { da educação na } \\
\text { área da história e } \\
\text { cultura africana e } \\
\text { afrodescendente. } \\
\text { Fortalecer o } \\
\text { desempenho acadêmico } \\
\text { e a participação } \\
\text { de estudantes } \\
\text { afrodescendentes da } \\
\text { Universidade Federal } \\
\text { do Piauí no ÍFARADÁ } \\
\text { como pesquisadores, } \\
\text { contribuindo para } \\
\text { a permanência dos } \\
\text { alunos na universidade, } \\
\text { através da concessão } \\
\text { de bolsas de trabalho } \\
\text { e bolsas de auxílio à } \\
\text { pesquisa }\end{array}$ \\
\hline
\end{tabular}




\begin{tabular}{|c|c|c|c|}
\hline Título/Instituição & Objetivo & Conclusão & Ações realizadas \\
\hline $\begin{array}{l}\text { 8. Universidade } \\
\text { Federal de } \\
\text { Uberlândia }\end{array}$ & $\begin{array}{l}\text { Projeto de Apoio } \\
\text { ao Núcleo de } \\
\text { Estudos Afro- } \\
\text { brasileiros da } \\
\text { Universidade } \\
\text { Federal de } \\
\text { Uberlândia } \\
\text { (NEAB/UFU) }\end{array}$ & 2007 & $\begin{array}{l}\text { Formação de } 124 \\
\text { (meta original:200) } \\
\text { professores em gênero, } \\
\text { raça e etnia e realizar } \\
\text { publicação sobre a } \\
\text { experiência }\end{array}$ \\
\hline $\begin{array}{l}\text { 9. Universidade } \\
\text { Federal de Alagoas }\end{array}$ & & & $\begin{array}{l}\text { Promoção de debates } \\
\text { com professores e } \\
\text { alunos da universidade. } \\
\text { Publicar revista Kulé } \\
\text { Kulé com os artigos do } \\
\text { Programa Afroatitude } \\
\text { da Universidade } \\
\text { Federal de Alagoas }\end{array}$ \\
\hline $\begin{array}{l}\text { 10. Universidade } \\
\text { Estadual de Goiás }\end{array}$ & $\begin{array}{l}\text { O objeto do } \\
\text { Convênio é } \\
\text { realizar pesquisa } \\
\text { sócio-cultural } \\
\text { e étnico- } \\
\text { racial junto a } \\
\text { professores e } \\
\text { alunos do Estado } \\
\text { de Goiás; realizar } \\
\text { a capacitação de } \\
\text { professores da } \\
\text { rede pública de } \\
\text { ensino do Estado } \\
\text { de Goiás e } \\
\text { publicar apostila } \\
\text { instrumental } \\
\text { para professores } \\
\text { sobre a Lei } \\
\text { 10.639/2003 }\end{array}$ & 2008 & $\begin{array}{l}\text { O curso de extensão em } \\
\text { educação das relações } \\
\text { étnico-raciais teve carga } \\
\text { horária de } 45 \text { (quarenta } \\
\text { e cinco) horas e através } \\
\text { dele foram formados } \\
440 \text { (quatrocentos e } \\
\text { quarenta) professores } \\
\text { das redes estadual e } \\
\text { municipal de ensino, } \\
\text { residentes em } 83 \\
\text { (oitenta e três) } \\
\text { municípios do estado } \\
\text { de Goiás. Foram } \\
\text { produzidos, através } \\
\text { do convênio, 1.500 } \\
\text { (mil e quinhentos) } \\
\text { exemplares da apostila } \\
\text { instrucional sobre } \\
\text { história e cultura afro- } \\
\text { brasileira e africana. } \\
\text { Estes exemplares foram } \\
\text { distribuídos na rede } \\
\text { pública de ensino do } \\
\text { Estado de Goiás }\end{array}$ \\
\hline
\end{tabular}




\begin{tabular}{|c|c|c|c|}
\hline Título/Instituição & Objetivo & Conclusão & Ações realizadas \\
\hline $\begin{array}{l}\text { 11. Universidade } \\
\text { Estadual de Santa } \\
\text { Cruz }\end{array}$ & $\begin{array}{l}\text { "Bantu-iê: Africa- } \\
\text { Brasil e Educação } \\
\text { das Relações } \\
\text { Étnico-Raciais" }\end{array}$ & 2009 & $\begin{array}{l}\text { Curso de especialização } \\
\text { lato-sensu: Educação } \\
\text { e Relações Étnico- } \\
\text { Raciais” com } 37 \\
\text { concluintes (meta } \\
\text { original: } 60 \text { ) Formação } \\
\text { de grupos de pesquisa } \\
\text { em } 12 \text { municípios, } \\
\text { posteriormente } \\
\text { reduzidos a 10, e } \\
\text { finalmente sem a } \\
\text { comprovação da efetiva } \\
\text { formação dos grupos de } \\
\text { pesquisa }\end{array}$ \\
\hline $\begin{array}{l}\text { 12. Universidade } \\
\text { Estadual do Sudoeste } \\
\text { da Bahia }\end{array}$ & $\begin{array}{l}\text { Criação de } \\
\text { banco de dados } \\
\text { de publicações, } \\
\text { pesquisas, obras } \\
\text { de arte sobre a } \\
\text { questão étnico- } \\
\text { racial; realização } \\
\text { de um curso de } \\
\text { aperfeiçoamento } \\
\text { em educação das } \\
\text { relações étnico- } \\
\text { raciais; apoio à } \\
\text { permanência de } \\
\text { estudantes afro- } \\
\text { descendentes na } \\
\text { Universidade }\end{array}$ & & $\begin{array}{l}\text { O curso de } \\
\text { aperfeiçoamento em } \\
\text { educação das relações } \\
\text { étnico-raciais teve carga } \\
\text { horária para } 130 \text { (cento } \\
\text { e trinta) professores } \\
\text { das redes estadual e } \\
\text { municipal de ensino, } \\
4 \text { seminários sobre } \\
\text { a temática étnico- } \\
\text { racial, que atingiram } \\
\text { a um público de } 800 \\
\text { (oitocentos) professores } \\
\text { da rede pública de } \\
\text { ensino da região do } \\
\text { sudoeste da Bahia. } \\
\text { Foram adquiridos, } \\
\text { exemplares de livros } \\
\text { raros sobre a temática } \\
\text { étnico-racial. Realizadas } \\
\text { exposições sobre } \\
\text { história e cultura afro- } \\
\text { brasileira e africana } \\
\text { e foram publicadas } \\
\text { cartilhas sobre a } \\
\text { temática, que foram } \\
\text { distribuídas a alunos da } \\
\text { UESB e a professores da } \\
\text { rede pública de ensino }\end{array}$ \\
\hline
\end{tabular}




\begin{tabular}{|c|c|c|c|}
\hline Título/Instituição & Objetivo & Conclusão & Ações realizadas \\
\hline $\begin{array}{l}\text { 13. Universidade do } \\
\text { Estado do Rio de } \\
\text { Janeiro }\end{array}$ & $\begin{array}{l}\text { Projeto "II } \\
\text { Programa de } \\
\text { Formação e } \\
\text { Permanência de } \\
\text { Afro-Brasileiros } \\
\text { da UERJ- } \\
\text { NEABUREJ" }\end{array}$ & 2008 & $\begin{array}{l}\text { Oferta de auxílio } \\
\text { acadêmico a } 11 \\
\text { estudantes de } \\
\text { graduação e a } 02 \\
\text { estudantes de pós- } \\
\text { graduação; realização } \\
\text { de seminários sobre a } \\
\text { temática étnico-racial. } \\
\text { II Curso de Extensão } \\
\text { História e Cultura } \\
\text { negra, destinado a } \\
\text { alunos de graduação e } \\
\text { 144 professores da rede } \\
\text { pública de ensino da } \\
\text { Baixada Fluminense }\end{array}$ \\
\hline $\begin{array}{l}\text { 14. Universidade do } \\
\text { Estado da Bahia }\end{array}$ & $\begin{array}{l}\text { AFROUNEB II: } \\
\text { ações afirmativas, } \\
\text { igualdade racial } \\
\text { e compromisso } \\
\text { social na } \\
\text { construção de } \\
\text { uma nova cultura } \\
\text { universitária }\end{array}$ & 2009 & $\begin{array}{l}\text { Revista em quadrinhos; } \\
\text { livro para-didático } \\
\text { e catálogo de } \\
\text { personagens negros. } \\
\text { Bolsas de permanência } \\
\text { para estudantes negros }\end{array}$ \\
\hline $\begin{array}{l}\text { 15. Universidade } \\
\text { Estadual de Minas } \\
\text { Gerais }\end{array}$ & $\begin{array}{l}\text { Produção de } \\
\text { material didático } \\
\text { em educação das } \\
\text { relações étnico- } \\
\text { raciais }\end{array}$ & 2008 & $\begin{array}{l}\text { O convênio de } 2006 \text { foi } \\
\text { reformalizado em } 2007 \\
\text { em virtude em atrasos } \\
\text { no pregão. }\end{array}$ \\
\hline
\end{tabular}

Fonte: Elaborado pela autora desta obra

\subsubsection{Exercício de 2008}

Os projetos a serem apoiados em 2008, foram regidos pela Resolução 14/2008. Contudo, tal Resolução foi alterada pela n. 26 de 26 de junho de 2008, em virtude da solicitação de extensão do prazo. A comissão técnica que avaliou os projetos foi constituída por Portaria n. 910 no dia 4 de julho de 2008. 
No dia 15 de setembro de 2008, foi publicada a Portaria Conjunta n. 01, apresentando as instituições selecionadas conforme Quadro 8.

Quadro 8 - Instituições Selecionadas/Edital 2008

\begin{tabular}{|c|c|}
\hline \multicolumn{2}{|l|}{ Material Didático-Pedagógico } \\
\hline Instituição & Valor do Projeto \\
\hline 1. Universidade Federal de São Carlos & $\mathrm{R} \$ 140.000,00$ \\
\hline 2. Universidade Federal do Rio Grande do Sul & $\mathrm{R} \$ 117.650,00$ \\
\hline \multicolumn{2}{|l|}{ Formação de Professores } \\
\hline Instituição & Valor do Projeto \\
\hline 1. Universidade Federal Rural do Rio de Janeiro & $\mathrm{R} \$ 150.000,00$ \\
\hline 2. Universidade do Estado de Mato Grosso & $\mathrm{R} \$ 111.990,50$ \\
\hline 3. Universidade do Estado do Mato Grosso do Sul & $\mathrm{R} \$ 129.381,00$ \\
\hline 4.Universidade Federal do Espírito Santo & $\mathrm{R} \$ 150.000,00$ \\
\hline 5. Universidade Estadual do Oeste do Paraná & $\mathrm{R} \$ 133.460,00$ \\
\hline 6. Universidade Federal de Minas Gerais & $\mathrm{R} \$ 150.000,00$ \\
\hline 7. Universidade Federal do Maranhão & $\mathrm{R} \$ 137.200,00$ \\
\hline 8. Universidade do Estado do Rio de Janeiro & $\mathrm{R} \$ 150.000,00$ \\
\hline 9. Universidade Federal Fluminense & $\mathrm{R} \$ 150.000,00$ \\
\hline 10. Universidade Federal de Mato Grosso & $\mathrm{R} \$ 149.800,00$ \\
\hline 11. Universidade Federal de Santa Maria & $\mathrm{R} \$ 142.490,00$ \\
\hline 12. Universidade Federal de Uberlândia & $\mathrm{R} \$ 147.884,00$ \\
\hline 13. Universidade Federal do Rio de Janeiro & $\mathrm{R} \$ 113.860,00$ \\
\hline 14. Universidade Estadual do Sudoeste da Bahia & $\mathrm{R} \$ 120.000,00$ \\
\hline 15. Universidade Federal do Paraná & $\mathrm{R} \$ 150.000,00$ \\
\hline 16. Universidade Federal de Juiz de Fora & $\mathrm{R} \$ 129.165,00$ \\
\hline 17. Universidade Federal de Roraima & $\mathrm{R} \$ 149.950,00$ \\
\hline 18. Universidade Federal do Tocantins & $\mathrm{R} \$ 102.700,00$ \\
\hline 19 Universidade Federal Rural de Pernambuco & R\$ $105.949,90$ \\
\hline 20. Centro de Ensino Federal Tecnológico do Pará & $\mathrm{R} \$ 150.000,00$ \\
\hline 21. Universidade Federal do Piauí & $\mathrm{R} \$ 100.000,00$ \\
\hline 22. Universidade Federal da Bahia & $\mathrm{R} \$ 149.920,00$ \\
\hline 23. Universidade Federal de Alagoas & $\mathrm{R} \$ 121.639,30$ \\
\hline 24. Universidade Federal do Recôncavo da Bahia & $\mathrm{R} \$ 128.080,00$ \\
\hline $\begin{array}{l}\text { 25. Universidade Federal dos Vales do Jequitinhonha e } \\
\text { Mucuri }\end{array}$ & $\mathrm{R} \$ 150.000,00$ \\
\hline
\end{tabular}

Fonte: Adaptado de SECAD (2008, p. 11) 
É importante reiterar que, a partir de 2008, há a definição das linhas de ações de forma mais específica, assim os projetos a serem apresentados pelas instituições tinham o objetivo de formar docentes ou produzir material didático. Analisando-se exclusivamente a formação de docentes, os projetos realizados por meio desse edital foram organizados no seguinte quadro:

Quadro 9 - Resultados dos Convênios/2008

\begin{tabular}{|c|c|c|c|}
\hline UF & Instituição & $\begin{array}{l}\text { Docentes } \\
\text { formados }\end{array}$ & Conclusão \\
\hline $\mathrm{AL}$ & 1. Universidade Federal de Alagoas & 600 & 2009 \\
\hline \multirow{3}{*}{$\mathrm{BA}$} & $\begin{array}{l}\text { 2. Universidade Estadual do Sudoeste da } \\
\text { Bahia }\end{array}$ & 350 & 2011 \\
\hline & 3. Universidade Federal da Bahia & 500 & 2010 \\
\hline & $\begin{array}{l}\text { 4. Universidade Federal do Recôncavo da } \\
\text { Bahia }\end{array}$ & 150 & 2010 \\
\hline $\mathrm{CE}$ & 5. Universidade Federal do Ceará & 50 & 2009 \\
\hline DF & 6. Fundação Universidade de Brasília & 200 & \\
\hline \multirow[t]{2}{*}{ ES } & $\begin{array}{l}\text { 7. Instituto Federal da Educ. Ciência e } \\
\text { Tecnologia do Espírito Santo }\end{array}$ & 50 & \\
\hline & 8. Universidade Federal do Espírito Santo & 120 & 2010 \\
\hline MA & 9. Universidade Federal do Maranhão & 40 & 2010 \\
\hline \multirow{4}{*}{ MG } & 10. Universidade Federal de Juiz de Fora & 40 & 2010 \\
\hline & 11. Universidade Federal de Minas Gerais & 180 & 2011 \\
\hline & 12. Universidade Federal de Uberlândia & 60 & 2010 \\
\hline & $\begin{array}{l}\text { 13. Universidade Federal dos Vales do } \\
\text { Jequitinhonha e Mucuri }\end{array}$ & 960 & 2010 \\
\hline MS & $\begin{array}{l}\text { 14. Universidade do Estado do Mato } \\
\text { Grosso do Sul }\end{array}$ & 80 & 2011 \\
\hline \multirow[t]{2}{*}{ MT } & $\begin{array}{l}\text { 15. Universidade do Estado de Mato } \\
\text { Grosso }\end{array}$ & 60 & Em andamento \\
\hline & 16. Universidade Federal de Mato Grosso & 50 & 2010 \\
\hline PA & $\begin{array}{l}\text { 17. Instituto Federal de Educação, Ciência } \\
\text { e Tecnologia do Pará }\end{array}$ & 200 & 2009 \\
\hline $\mathrm{PE}$ & $\begin{array}{l}\text { 18. Universidade Federal Rural de } \\
\text { Pernambuco }\end{array}$ & 300 & 2010 \\
\hline PI & 19. Universidade Federal do Piauí & 700 & \\
\hline
\end{tabular}




\begin{tabular}{|l|l|c|c|}
\hline \multirow{2}{*}{ UF } & Instituição & $\begin{array}{c}\text { Docentes } \\
\text { formados }\end{array}$ & Conclusão \\
\hline \multirow{2}{*}{ PR } & $\begin{array}{l}\text { 20. Universidade Estadual do Oeste do } \\
\text { Paraná }\end{array}$ & 50 & 2012 \\
\cline { 2 - 4 } & 21. Universidade Federal do Paraná & 550 & \\
\hline \multirow{2}{*}{ RJ } & 22. Universidade Federal do Rio de Janeiro & 210 & 2010 \\
\cline { 2 - 4 } & 23. Universidade Federal Fluminense & 615 & Em andamento \\
\cline { 2 - 4 } & $\begin{array}{l}\text { 24. Universidade Federal Rural do Rio de } \\
\text { Janeiro }\end{array}$ & 50 & 2010 \\
\hline \multirow{2}{*}{ RR } & 25. Universidade Federal de Roraima & 50 & 2012 \\
\hline RS & 26. Universidade Federal de Santa Maria & 60 & Em andamento \\
\hline TO & 27. Universidade Federal do Tocantins & 60 & \\
\hline
\end{tabular}

Fonte: Elaborado pela autora desta obra

\subsubsection{Exercício de 2009}

Conforme explicitado anteriormente, o último edital do Uniafro foi o de Convocação 18/2009. Não foram publicadas no DOU informações sobre a data e composição da comissão de seleção.

No dia 4 de setembro de 2009, foi publicado o Edital 25, da SECAD, com as seguintes instituições selecionadas pelo Edital 18/2009:

Quadro 10 - Instituições Selecionadas/Edital 2009

\begin{tabular}{|l|c|}
\hline Instituição & Valor do Projeto \\
\hline 1. UFRGS & $\mathrm{R} \$ 242.380,00$ \\
\hline 2. UFCE & $\mathrm{R} \$ 201.760,00$ \\
\hline 3. UFMG & $\mathrm{R} \$ 342.910,00$ \\
\hline 4. UNIMONTES & $\mathrm{R} \$ 1.185 .448,75$ \\
\hline 5. UFPA & $\mathrm{R} \$ 75.000,00$ \\
\hline 6. UFRJ & $\mathrm{R} \$ 146.060,00$ \\
\hline 7. USP & $\mathrm{R} \$ 89.760,00$ \\
\hline 8. UFF & $\mathrm{R} \$ 150.000,00$ \\
\hline 9. UFJF & $\mathrm{R} \$ 138.448,00$ \\
\hline 10. UFRRJ & $\mathrm{R} \$ 150.000,00$ \\
\hline
\end{tabular}




\begin{tabular}{|l|c|}
\hline Instituição & Valor do Projeto \\
\hline 11. UFES & $\mathrm{R} \$ 376.082,00$ \\
\hline 12. IFRJ & $\mathrm{R} \$ 56.600,00$ \\
\hline 13. IFES & $\mathrm{R} \$ 75.507,80$ \\
\hline 14. UEL & $\mathrm{R} \$ 85.784,00$ \\
\hline Total & $\mathrm{R} \$ 3.315 .740,55$ \\
\hline
\end{tabular}

Fonte: Adaptado de SECAD (2009, p. 39)

Quando foi realizada a coleta de dados no MEC, em 2012, somente um dos projetos apoiados pelo Uniafro, em 2009, havia sido concluído. A situação dos projetos foi organizada no Quadro 11.

Quadro 11 - Resultados dos Convênios/2009

\begin{tabular}{|c|c|c|c|}
\hline Instituição & UF & $\begin{array}{c}\text { Professores } \\
\text { formados }\end{array}$ & Situação \\
\hline 1. Universidade Federal do Ceará & $\mathrm{CE}$ & 50 & Em andamento \\
\hline $\begin{array}{l}\text { 2. Universidade Federal do Espírito } \\
\text { Santo }\end{array}$ & ES & 200 & Em andamento \\
\hline $\begin{array}{l}\text { 3. Instituto Federal da Educ. Ciência e } \\
\text { Tecnologia do Espírito Santo }\end{array}$ & ES & 50 & Concluído \\
\hline 4. Universidade Federal de Minas Gerais & MG & 80 & Em andamento \\
\hline 5. Universidade Federal de Juiz de Fora & MG & 40 & Em andamento \\
\hline $\begin{array}{l}\text { 6. Universidade Estadual de Montes } \\
\text { Claros }\end{array}$ & MG & 1730 & Aguardando recursos \\
\hline 7. Universidade Federal do Pará & PA & 60 & \\
\hline 8. Universidade Estadual de Londrina & $\mathrm{PR}$ & 70 & Aguardando recursos \\
\hline 9. Universidade Federal Fluminense & $\mathrm{RJ}$ & 50 & Em andamento \\
\hline $\begin{array}{l}\text { 10. Centro Federal de Educação } \\
\text { Tecnológica do Rio de Janeiro }\end{array}$ & RJ & 35 & Em andamento \\
\hline $\begin{array}{l}\text { 11. Universidade Federal Rural do Rio } \\
\text { de Janeiro }\end{array}$ & RJ & 50 & Em andamento \\
\hline $\begin{array}{l}\text { 12. Universidade Federal do Rio de } \\
\text { Janeiro }\end{array}$ & RJ & 60 & Em andamento \\
\hline $\begin{array}{l}\text { 13. Universidade Federal do Rio } \\
\text { Grande do Sul }\end{array}$ & RS & 500 & Em andamento \\
\hline 14. Universidade de São Paulo & SP & 200 & Aguardando recursos \\
\hline
\end{tabular}

Fonte: Elaborado pela autora desta obra 


\subsubsection{Análise}

Ao longo de sete anos, por meio do Uniafro, foram formados 17.070 professores, produzidos 53 materiais didáticos de apoio à implementação da educação das relações étnico-raciais e fornecidas 190 bolsas de permanência para estudantes negros. Contudo, o programa teve sérios problemas de execução, além de mudanças nos seus objetivos ao longo da sua implementação.

A princípio, o objetivo era fortalecer os NEAB e fornecer apoio à pesquisa e publicação sobre a temática da educação das relações étnico-raciais e fornecer bolsas de permanência para alunos negros e formação para docentes, mas a partir de 2008, há a mudança de enfoque deslocando a ênfase para a formação dos docentes em educação das relações étnico-raciais, com uma linha dedicada à formação direta, por meio da oferta de cursos aos docentes, e outra linha voltada ao apoio e formação indireta, por meio da publicação de instrumentos didáticos voltados à temática.

Também foi alterada a forma de organização das instituições a fim de realizarem seus projetos. Nos primeiros editais, havia a possibilidade de uma mesma instituição promover todas as linhas de ação previstas. A partir de 2008, as instituições deveriam escolher destinarem ações para a formação de docentes ou para a publicação, sendo que a maior quantidade de projetos a serem apoiados era na linha temática de formação de docentes.

Para analisar a efetividade do Uniafro seria necessário realizar pesquisa qualitativa, analisando todos os 69 convênios do programa, e, também, a sua execução, além de coleta de informações das instituições de ensino executoras, das secretarias de educação municipal e dos professores.

Contudo, o objetivo neste estudo é avaliar a implementação do Uniafro sobre o seu aspecto de política de formação de docentes em educação das relações étnico-raciais. Para tanto, além de 
avaliar aspectos de sua implementação identificados, são necessárias avaliações de como esse instrumento se relaciona com o problema geral da falta de professores capacitados para ministrar o conteúdo da educação das relações étnico-raciais.

Primeiro, é importante destacar as limitações que o uso do instrumento de editais de seleção de projetos traz para a implementação de políticas públicas universais. É imperioso destacar que a obrigatoriedade do ensino de educação das relações étnico-raciais é uma política valorativa de promoção da igualdade racial, instituída por uma alteração na LDB que regula a educação em todos os estabelecimentos de ensino da educação básica.

Assim, a formação de docentes para a implementação dessa política dialoga com o universo dos mais de 300 mil estabelecimentos de ensino de educação básica do Brasil, também se deve considerar que essa formação de docentes ocorre em instituições de ensino superior públicas e particulares.

Nesse contexto, implementar uma política de estímulo de formação por meio da seleção dos melhores projetos, significa que não é possível realizar uma atenção universal, ou pela falta de recursos, ou pela falta de capacidade técnica de instituições de todas as unidades da federação de executarem esses projetos. Isso, sem mencionar o papel nada desprezível das instituições particulares de ensino superior na formação de docentes no País.

Nesse contexto, duas questões merecem destaque no uso desse modelo de implementação: em que medida os critérios de seleção de projetos por qualidade são isonômicos e tangíveis e se selecionar os melhores projetos significa excluir locais que, até mesmo pelas condições de suas instituições públicas de ensino superior não têm possibilidades de realizar essas formações, sendo que essas são as mais vulneráveis e necessitadas de tal tipo de ação. 
A falta de capacidade técnica e/ou acadêmica para a realização de cursos de formação para docentes nessa temática deveria ser um fator de atenção do poder público para a priorização. Porém, dentro desse modelo de seleção, é um impeditivo ao exercício de ações voltadas aos docentes nas localidades mais carentes.

Inclusive, é importante destacar que por meio de editais de seleção com um limite orçamentário tão pequeno (em torno de 3 milhões por ano), poucas instituições seriam contempladas mesmo na continuidade da política ano após ano. E sem limitações a mesma instituição concorrer repetidamente, as chances de alcance a regiões diversas com iguais ou maiores necessidades era muito limitada, e sem uma relação entre essa escolha de qual instituição seria contemplada e a realidade local (quantidade de docentes, escolas, etc), essa política não parece apta a contemplar da necessidade de capacitação de milhões de professores nessa temática.

Sem contar que, com a continuidade das seleções, a tendência é de as instituições que têm condições de realizarem seus projetos, continuamente aprimorarem-se tanto no que se refere ao modelo de execução do curso, quanto à elaboração dos projetos, enquanto as demais, consecutivamente se afastam dessa possibilidade.

Ao longo dos oito anos de implementação do Uniafro, foram contemplados projetos em todos os estados das regiões Sul, Sudeste e Centro-Oeste. Na região Norte, foram apoiados projetos no Pará, Roraima e Tocantins e no Nordeste nos estados da Bahia, Pernambuco, Alagoas, Ceará e Piauí. Ou seja, não houve apoio a ações nos estados do Acre, Amapá, Amazonas, Rondônia, Rio Grande do Norte, Paraíba e Sergipe. Ao mesmo tempo em que, em todas as edições houve apoio a projetos no Rio de Janeiro e na Bahia.

Destaca-se que, até 2007, os convênios formados por meio dos editais do Uniafro estavam sujeitos ao Decreto n. 1.819, de 16 de fevereiro de 1996, que estabelecia a forma de repasse de 
recursos para instituições federais. A partir de 2007, houve significativas alterações na legislação por meio dos Decretos n. 6.170, de 25 de julho de 2007, e n. 6.428, de 14 de abril de 2008, entre as quais destaca-se o provável impacto no modelo do Uniafro pela proibição da celebração de convênios abaixo de R $\$ 100.000,00$ e a obrigatoriedade do cadastramento das propostas no Sistema de Gestão de Convênios e Contratos de Repasse (SICONV).

Assim, além da questão da necessidade de capacidade técnica das instituições para construir seus projetos para a celebração dos convênios com o MEC no âmbito do Uniafro, a partir de 2008, houve a necessidade de capacitação para gerenciar o projeto utilizando o SICONV.

A fim de acompanhar os projetos referentes ao edital de 2006, foi construído um instrumento de avaliação do andamento das ações do convênio, que deveria ser enviado para o MEC, o Relatório Parcial - Uniafro 2006. Algumas instituições destacaram em seus relatórios, apontamentos relevantes para o que consideraram os problemas para a gestão dos projetos do Uniafro: i) dificuldade de celebração e pagamento dos projetos; ii) incipiente estágio de articulação entre os NEAB e baixa institucionalização desses núcleos nas instituições públicas de ensino superior; iii) dependência do convênio com o MEC para a continuidade dos projetos.

Essas questões apontadas, serão analisadas caso a caso, a partir das informações já apresentadas sobre as quatro edições do Uniafro.

\subsubsection{Dificuldade de celebração e pagamento dos projetos}

Em todas as edições houve grandes problemas para a celebração dos convênios. É importante destacar, que na maioria dos anos, os editais foram lançados no mês de abril. Nos anos de 2005 e 2006, os projetos aprovados foram publicados em meados de 
junho, e os convênios começaram a serem celebrados em dezembro, ou seja, do lançamento do edital à formalização do convênio foram gastos oito meses.

Assim, em praticamente todos os casos, houve a necessidade de extensão do prazo de execução dos projetos, chegando a até três anos o período de realização dos convênios, que, em tese, deveriam ser executados em dez meses.

No caso dos convênios de 2008 e 2009, esse tipo de problema foi exponencialmente aumentado. Nesses anos, os editais foram lançados em junho e julho, as instituições selecionadas em setembro, e a celebração dos convênios ao longo dos anos seguintes.

Dos 27 convênios firmados em 2008, 11 tiveram que ser recelebrados, em virtude da devolução de recursos para o FNDE devido a não realização dos projetos no período determinado. Assim, tiveram que ser realizados procedimentos administrativos para que o FNDE devolvesse às instituições os recursos necessários à realização dos projetos, o que gerou atrasos de anos.

No caso dos convênios de 2009, até o ano de 2012, somente um dos 14 havia sido concluído, sendo que três ainda estavam aguardando o repasse de recursos do MEC.

Assim, é evidente o sério problema na capacidade do MEC e/ou das instituições estaduais e municipais em executar os trâmites burocráticos necessários à formalização do instrumento de repasse. Além disso, é importante indicar que esse problema inicial tem sérios impactos para o planejamento do curso como um todo.

É necessário frisar que quando realizado o projeto, todo o orçamento é elaborado a partir de referências datadas. Atrasos substanciais como o apresentado, ocasionam revisão de todo o plano de trabalho.

Outra questão importante gerada por esse problema é a capacidade técnica da Coordenação de Educação das Relações 
Étnico-raciais da SECADI em acompanhar tantos projetos simultaneamente. A cada ano, além de celebrar os convênios novos, a coordenação também teve que lidar com os trâmites burocráticos para a celebração dos antigos, ainda pendentes de formalização, os inúmeros aditivos de prazo e o andamento e acompanhamento dos projetos.

3.2.3.2 Incipiente estágio de articulação entre os NEAB e a baixa institucionalização dos núcleos nas instituições públicas de ensino superior

É importante destacar, especificamente aos editais de 2005 e 2006 tinham como objetivo a consolidação e fortalecimento dos NEAB entre os objetivos do Uniafro. Contudo, a consolidação dos NEAB é importante para a consolidação da política de educação das relações étnico-raciais como um todo, porque a pesquisa e publicação sobre a temática são condições de existência da revisão dos conteúdos didáticos.

Porém, ainda que a realização de um edital específico para dotar os NEAB de recursos financeiros e, assim, consequentemente, atribuir aos núcleos mais importância e prestígio dentro de suas instituições, essa é uma questão a ser repensada. Em que medida essa ação, descolada de ações vinculadas às linhas de pesquisa apoiadas pela Coordenação de Pessoal de Nível Superior (Capes) e pelo Conselho Nacional de Desenvolvimento Científico e Tecnológico $(\mathrm{CNPq})$ tem efetividade? Ou mesmo das ações afirmativas na pós-graduação e na carreira docente? ${ }^{30}$

\footnotetext{
30 No período de 2010 a 2013, nem a Capes, nem o CNPq promoveram alguma linha de pesquisa específica para as relações étnico-raciais, sendo que, há menção da temática no processo de inscrição de instituições interessadas em participar do Programa Institucional de Bolsas de Iniciação Científica nas Ações Afirmativas PIBIC-AF.
} 
Se por um lado, para efetivar a consolidação dos NEAB como núcleos de pesquisa e formação para a temática das relações étnico-raciais relevantes nos contextos universitários, é necessário prover de condições mínimas de trabalho a sua infra-estrutura, por outro, é importante que haja apoio às pesquisas a serem desenvolvidas nesses núcleos.

Ainda que se possa afirmar que há uma série de linhas de pesquisas não específicas que contemplariam esse tipo de projeto, a necessidade da priorização é justificada tanto pela legislação, quanto pela expressão da real importância que essa temática deveria ter dentro das ações do Ministério da Ciência e Tecnologia.

No que tange às ações afirmativas na carreira docente, é mister destacar que a mesma argumentação válida para a adoção de ações afirmativas entre alunos das instituições públicas de ensino superior, quanto à importância de tornar o ambiente acadêmico diverso e promover mecanismos de inclusão da população negra, é relevante para a pós-graduação e a carreira docente, sendo que no caso específico da carreira docente, em muitos casos, a inclusão dos sujeitos negros vem articulada com objetos de pesquisa e temáticas afrocentradas.

Talvez, essa ação seja muito relevante como um estímulo à criação dos NEAB, uma vez que, as instituições que não os possuíssem vissem neles a possibilidade de apoio ao financiamento de projetos. Contudo, nas instituições que já os possuíam, esse apoio é controverso.

Dada a dificuldade de realização desses projetos e a necessidade de um conhecimento técnico para a sua realização, conforme explicitado anteriormente, somente os NEAB já relativamente consolidados teriam condições de participar, e os problemas para a realização dos projetos parecem mais um entrave para a consolidação do que um incentivo à sua efetivação. 


\subsubsection{Dependência do convênio com o MEC para a continuidade dos projetos}

Uma das principais causas para o incentivo à realização de projetos como o Uniafro é a crença de que o estímulo à pesquisa e desenvolvimento de metodologia de ensino nessa temática são ações que, uma vez iniciadas, facilmente podem ser continuadas. Uma vez criado um curso, por exemplo, os esforços realizados para a construção dos conteúdos e da metodologia poderiam ser menores nas edições seguintes, com a realização somente de atualizações periódicas.

Faz-se necessário destacar que a construção do objetivo de formar docentes para a implementação da educação das relações étnico-raciais já é uma atribuição das IES. Contudo, para a efetivação dos mecanismos de implementação da educação das relações étnico-raciais é necessária a formação continuada de docentes que não foram apresentados a tais conteúdos e também a mudança no currículo das licenciaturas para a garantia da formação dos novos profissionais com a formação adequada ao novo momento histórico.

Porém, esse desafio é extremamente denso. Por um lado, as instituições teriam a obrigação de já estarem ofertando disciplinas que possibilitassem a formação dos seus licenciados nessa temática, ação essa avaliada no capítulo anterior; por outro, formar docentes em exercício é um projeto em longo prazo $^{31}$, com o qual o Uniafro não pôde ajudar substancialmente.

31 A questão do desafio da formação de docentes no Brasil é imensa. A partir de 1996, com a instituição da LDB, que torna obrigatória a formação superior para a prática docente, foram realizados diversos esforços no sentido da garantia dessa formação, contudo, segundo dados do Censo Escolar (INEP, 2011), aproximadamente $25 \%$ dos professores não possuem o nível superior, 18 anos após a aprovação da LDB. 


\section{Conclusão}

Ao longo da pesquisa apresentada, foram discorridos pontos que serão agora brevemente retomados a fim de sintetizar os argumentos e sistematizar aprendizados relativos ao objetivo do estudo: análisar a formação de docentes para a implementação da educação das relações étnico-raciais a partir dos Programas Africanidades e Uniafro do MEC.

No primeiro capítulo foram descritas e organizadas as políticas de promoção da igualdade a partir do conceito de Jaccoud e Beghin (2002), que aglutina três objetivos desse tipo de política pública. A vantagem no uso desse conceito é que ele possibilita superar a limitação semântica da igualdade racial, e classificar "políticas de igualdade racial" como um conjunto de ações que agrega o enfrentamento ao racismo, as ações afirmativas, a valorização da cultura negra e a repressão à discriminação racial.

Contudo, há entraves na execução das políticas de promoção da igualdade racial, com destaques para as dificuldades de execução das ações como observado, também, no Programa Brasil Quilombola e pela a fragilidade da legislação.

Há que se pesar os entraves políticos e institucionais no processo tanto de esvaziamento do que efetivamente a legislação obriga, quanto da relação que a secretaria coordenadora dessas ações pode vir a estabelecer com os órgãos executores das ações e do orçamento. 
Tal constatação corrobora a independência dos ciclos proposta por Kingdom (1995), uma vez que as consequências do racismo ensejam várias entradas na agenda decisória governamental, conforme explicitado no Capítulo 1 com a ênfase nas ações articuladas por entidades da militância negra em 1950, 1986 e 1995, sendo que a Marcha Zumbi dos Palmares, contra o Racismo, pela Cidadania e pela Vida, em 1995, culminou com a adoção de uma série de ações que atualmente conformam a Política Nacional de Promoção da Igualdade Racial.

Porém, as soluções demandas por essa militância não são necessariamente as políticas adotadas pelo governo federal. Exatamente porque os ciclos são independentes, não há necessariamente uma sintonia entre problema, solução e política.

No caso específico do Estatuto da Igualdade Racial, de autoria do Senador Paulo Paim, muitos dos elementos do texto original versavam sobre diversos pontos da pauta dessa militância, no que tange à adoção de ações afirmativas e na estruturação e financiamento de políticas públicas voltadas à população negra. Contudo, o resultado final é uma lei que pouco institui para a promoção da igualdade.

No caso da Política Nacional de Promoção da Igualdade Racial do PLANAPIR, ocorre o mesmo, isto é versa sobre os temas que em tese contemplariam as demandas dessa militância, porém sem efetivar mecanismos de alcance dos objetivos relacionados a tais políticas.

Assim, mais do que a independência entre os ciclos dos problemas, das alternativas e das políticas, nesse caso específico há um momento de interseção com a entrada dessa temática na agenda, contudo, um esvaziamento do conteúdo transformador da realidade dos instrumentos que efetivariam a consecução da demanda. 
No que concerne especificamente à educação das relações étnico-raciais, analisada em detalhe no Capítulo 2, ainda que se observe uma legislação bem assertiva, a questão de como transformar a obrigatoriedade da legislação em uma prática concreta é igualmente problemática para a solução do problema da não inserção de conteúdo da história e cultura africana e afro-brasileira no conteúdo da educação básica.

É evidente o importante papel dos professores e das escolas na efetivação das ações, contudo, há que se pesar esse compartilhamento de responsabilidades conforme expresso no Plano de Implementação para identificar como e quanto a Política Nacional de Educação e de Promoção da Igualdade Racial tem contribuído para o cenário atual, em relação às dificuldades de sua própria implementação.

A educação das relações étnico-raciais é uma ação parte da Política de Promoção da Igualdade Racial, isso significa, na prática, três coisas, a princípio: i) que a Política decorre de herança de demandas históricas do movimento social negro; ii) que está em fase de implementação recente; iii) que tem uma dupla gestão, uma parte voltada a seu órgão executor, o MEC, e outra voltada ao órgão coordenador de políticas dessa natureza, a SEPPIR.

Essa dupla inserção, como política de educação e de promoção da igualdade racial não parece apresentar grandes dilemas nesse caso, ${ }^{32}$ porque, em que pese os apontamentos da pesquisa, boa parte das ações está no escopo de atuação e decisão exclusiva do MEC, a SEPPIR é uma coadjuvante, e talvez espectadora, nesse processo.

32 É importante destacar que no caso de outras políticas, como a Saúde da População Negra e as ações afirmativas na educação superior, parece haver uma maior relação entre o órgão executor e o coordenador, com pelo menos um fluxo de informações entre ambos. Contudo, mesmo em programas expressivos como o PBQ a SEPPIR não disponibiliza informações sobre ações do órgão executor. 
Contudo, talvez esse seja exatamente o principal dilema, uma vez que essa ausência da SEPPIR pode em parte ajudar a explicar o processo de esvaziamento das ações do MEC, com a descontinuidade de programas como o Uniafro, sem grandes soluções alternativas ao problema que visava combater.

No que concerne especificamente ao estado de implementação da educação das relações étnico-raciais, a ausência de diagnóstico é extremamente danosa para todo o planejamento demandado por essa política.

As avaliações apresentadas na pesquisa indicam a questão da baixa implementação como premissa das pesquisas. Ambos os resultados apontam para problemas no entendimento do que seria ministrar esse conteúdo tanto por parte dos docentes e equipe escolar, quanto dos gestores municipais, concluindo que há a necessidade de investimento em processos formativos.

Contudo, quando observada a formação em si, a partir da consulta realizada pela SEPPIR às IES, há sérios indícios de desentendimento também do que seria a implementação, além do investimento em formação complementar, em detrimento da específica, e a indefinição de critérios para o estabelecimento de parâmetros mínimos, ou mesmo um horizonte de implementação da educação das relações étnico-raciais no ensino superior com vistas à formação de docentes.

Os Programas Uniafro e Africanidades tiveram sob determinado recorte ${ }^{33}$ o mesmo objetivo, com estratégias diametralmente diferentes. Enquanto o Africanidades tentou por meio da EAD propagar uma formação única para professores das mais diversas

\footnotetext{
33 Resta evidente que o Uniafro era mais abrangente, especialmente nos dois primeiros editais, que o Africanidades, porém, ambos tinham entre seus objetivos a formação de docentes para a educação das relações étnico-raciais.
} 
unidades da federação e realidades educacionais do País, o Uniafro tentou, por meio da parceria com as instituições públicas de ensino superior, estimular a formação de docentes.

Conforme foi avaliado no Capítulo 3, ambos tiveram sérios problemas de gestão que em parte podem indicar um fracasso sob o ponto de vista da execução. Além disso, ainda que esses programas tivessem sido executados da forma prevista, alcançando os objetivos propostos, é importante reiterar o questionamento sobre se a solução apresentada por essas iniciativas dialoga com o escopo e abrangência do problema que visam combater.

Assim, a questão que permanece é: qual o aprendizado institucional que se pode extrair desses programas? Sabe-se que o Africanidades está na memória de quem participou, mas pouco na institucional do MEC. O Uniafro ainda é presente nos relatórios de gestão especialmente considerando a vigência de alguns dos convênios, com especial destaque para os milhares de docentes formados e materiais distribuídos, entretanto o que se pode concluir, haja vista a descontinuidade do programa e a pretensa incorporação do seu aspecto formativo na rede de formação de docentes? Esse tipo de programa não vai mais existir?

A formação de docentes não é uma política por si mesma, na qual o objetivo é a ação. Formar docentes tem uma intenção que se relaciona com os objetivos da educação básica, de formar o cidadão e fornecer o conhecimento mínimo necessário para o ingresso na vida profissional e/ou acadêmica. No caso específico da educação das relações étnico-raciais, há duas intenções bem claras: i) habilitar os profissionais para a inclusão da temática no currículo escolar; ii) possibilitar que os docentes identifiquem e combatam mecanismos de discriminação étnico-racial na sua prática institucional e no cotidiano da instituição.

Num contexto de formação, é possível aglutinar essas intenções, logo observando o material disponibilizado como texto-base 
do Africanidades, é clara a tentativa de possibilitar a apresentação de mecanismos de identificação e combate ao racismo assim como realizar a inserção dos conteúdos expressos na legislação.

Se por um lado o Africanidades teve problemas devido à extrema centralização das decisões em Brasília, a falta de um ponto de apoio institucional nos estados e a dificuldade de gestão de um curso com aquela proporção de alunos, por outro, havia um controle bem detalhado de todo o conteúdo e metodologia do curso, com a exata noção dos conhecimentos e habilidades que o docente concluinte em tese possuiria.

Já o Uniafro, ao utilizar as universidades como ponto de elaboração e execução dos cursos, delega a competência da execução e permanece somente com o acompanhamento, que seria realizado mediante sorteio.

Nesse aspecto, inclusive, o Uniafro apresenta alguns pontos positivos importantes para o desenho de políticas com esse objetivo. A primeira questão versa sobre a necessidade de incorporação dos estados e municípios às políticas de formação de docentes para a educação das relações étnico-raciais. Ainda que esse programa não fizesse isso diretamente, dado que as instituições apoiadas poderiam ser tanto federais quanto estaduais, é importante destacar que um ponto de apoio e coordenação nos estados é extremamente relevante para a coordenação de ações educativas, que, geralmente, demandam espaço físico, pessoal, equipamentos e materiais.

Outra ideia acertada do Uniafro refere-se exatamente à incorporação das universidades como parceiras na formação, porque em tese essas instituições têm a expertise, a capacidade de fornecer conteúdos de forma mais profunda, considerando a pretensa qualidade das instituições públicas de ensino superior.

Nesse aspecto, a instituição da Rede Nacional de Formação Continuada dos Profissionais do Magistério da Educação Básica 
Pública, em 2011, dialoga com essa contínua necessidade de promover a formação de docentes em parceria com as instituições públicas de educação superior do País, porém, o papel da formação voltada à educação das relações étnico-raciais na rede carece de evidenciamento.

Uma questão cerne para a discussão das políticas de promoção da igualdade racial discursa exatamente sobre a especificidade versus a universalidade. $\mathrm{O}$ fato de ter havido programas específicos para a formação de docentes em educação das relações étnico-raciais era um indício de uma atenção específica nessa temática.

A possibilidade de essa formação disputar com uma série de outras a sua participação na Rede é preocupante. Outra questão controversa é que houve problemas de acompanhamento em ambos os programas analisados. Contudo, no contexto da Rede, não está definido de que forma esse problema será sanado.

Assim, de modo geral, as experiências dos programas analisados, e, também, a consulta realizada pela SEPPIR e dos indicadores de formação propostas a partir dela, é possível apontar algumas questões para a construção de um modelo de formação de docentes com vistas à capacitação para ministrar o conteúdo da educação das relações étnico-raciais.

A fim de organizar as propostas, é preciso destacar a necessidade de se trabalhar em dois níveis: i) na formação de docentes nas licenciaturas; e ii) na capacitação de docentes já formados.

A primeira questão, e talvez mais problemática, é a formação nas IES. Ao mesmo tempo em que as capacitações voltadas a docentes possam habilitar milhares por ano, são inseridos no mercado dezenas de milhares de professores sem formação que inclua questões étnico-raciais.

Assim, o estímulo à formação de docentes, nas instituições públicas e particulares, é essencial para a garantia da não realização 
de um trabalho intransponível, na qual mais e mais professores são diplomados e exercem a docência sem formação que contemple a Lei $10.639 / 2003$, tendo que passar por formação específica a posteriori.

Contudo, é importante ponderar a qualidade da inserção dos conteúdos previstos em lei, haja vista que a criação de uma disciplina é insuficiente e a criação de pelo menos quatro (nas instituições que formam profissionais nas áreas de pedagogia, licenciatura de artes, história e letras) pode ser ambicioso para algumas instituições em um primeiro momento.

Assim, é necessário o estabelecimento do monitoramento da aplicação do Plano Nacional de Implementação da Educação das Relações Étnico-raciais no ensino superior, garantindo que as instituições estabeleçam metas de inserção para o alcance da formação ideal; estabelecendo que no curto prazo todas devam possibilitar a formação no nível básico, e no médio e longo prazo etapas para o alcance da formação ideal.

Ao mesmo tempo, são necessárias ações de estímulo à contratação de docentes nessa temática, e assim, a incorporação dessas linhas de pesquisa nas instituições. Para estimular essa incorporação, a existência de incentivos financeiros a pesquisa no âmbito do CNPq e da Capes seriam importantes, a exemplo do que já ocorre com outras áreas ${ }^{34}$, ou mesmo nas ações de incentivo a criação de programas de Pós-Graduação ${ }^{35}$.

Agora, no que se refere à capacitação de docentes, alguns apontamentos são resultado direto das observações no que tange

\footnotetext{
34 Nesse sentido, o Ministério da Saúde tem promovido projetos de pesquisa para incentivar pesquisadores a encontrar soluções inovadoras para serem aplicadas no Sistema Único de Saúde (SUS) e aprimorar o atendimento e a assistência ao usuário, por meio de parceria entre a Secretaria de Ciência, Tecnologia e Insumos Estratégicos (SCTIE e CNPq) e o Ministério da Ciência, Tecnologia e Inovação (MCTI).

35 No âmbito da Rede Universidade Aberta do SUS há o incentivo a programas de Pós-Graduação sobre a temática do SUS.
} 
ao Africanidades e ao Uniafro. Ao se trabalhar com um universo sabidamente gigantesco, de 2 milhões de professores, é necessário o desenvolvimento de um plano de capacitação que: i) priorize as disciplinas obrigatórias por lei; e ii) estabeleça e defina prazos para a consecução do plano.

Assim, o plano de capacitação deveria contemplar a estrutura da educação básica, considerada a necessidade de estabelecer metas para as séries iniciais, considerando que as profissionais da pedagogia desenvolvem as atividades nesse período; e as séries finais do ensino fundamental e o ensino médio, identificando como meta prioritária de inserção da temática em história, português e literaturas e artes.

Por fim, uma reflexão que permeou toda a pesquisa, principalmente depois de observada a tendência dos órgãos governamentais a dificultarem o acesso às informações sobre os programas pouco exitosos, foi exatamente: o que é o êxito das políticas públicas?

Ao longo da pesquisa foi observada uma série de problemas que vão desde a concepção à execução dos programas, ao esvaziamento organizativo e propositivo da legislação e não efetivação da transformação da pauta do movimento social em uma política pública integral. Entretanto, a impressão que fica é que esses problemas podem ser generalizados a um conjunto de políticas que passam pelas mais diversas áreas e temáticas.

O que este caso traz de específico, é que o conjunto dessas políticas, de promoção da igualdade racial, apesar de extremamente especializado, complexo e diverso é interligado ${ }^{36}$ para a consecução do problema que ele visa combater: a discriminação racial.

\footnotetext{
36 Se forem praticadas ações de repressão ao racismo na esfera penal, sem a reeducação da população e o empoderamento da população negra, não é possível o estabelecimento da equidade. Se a população negra ascender por meio de ações afirmativas, sem a educação antirracista e a repressão, não é possível a equidade. $\mathrm{E}$ se as ações educativas forem bem sucedidas, sem a repressão ao racismo e a promoção das pessoas negras, a equidade é impossível.
} 
Nesse caso específico da educação das relações étnico-raciais, no qual o desafio é imenso e as estratégias estabelecidas são de dificil execução são maiores ainda, o êxito viria na medida em que essa política: i) dialogasse com o problema que visa combater; ii) estivesse contextualizada com as soluções presentes na sociedade; iii) tivesse um horizonte temporal factível; iv) possuísse proposta de continuidade, ou de descontinuidade, mas com algum parâmetro. De modo geral, ainda que haja os parâmetros com relação ao que deve ser a implementação da educação das relações étnico-raciais, não há um projeto de implementação nesses moldes.

Assim, por meio deste trabalho, buscou-se contribuir com a implementação da educação das relações étnico-raciais na formação de docentes, em diálogo com o Eixo 5 - Avaliação e Monitoramento, do Plano Nacional de Implementação, ao propor os indicadores de implementação da formação de docentes no ensino superior, e com o Eixo 6 - Condições Institucionais, pela crítica aos modelos de implementação adotados nos Programas Africanidades e Uniafro, e a partir deles, apontar caminhos para os projetos de implementação a serem desenvolvidos.

De modo geral, ao longo da análise, observou-se que mesmo com alguns acertos e possibilidades, ambos os programas analisados não alcançam o escopo do problema da formação de docentes para a educação das relações étnico-raciais como ação estruturada e condizente com o problema da falta de formação. Tal constatação pode ser relacionada à ausência de compromisso efetivo, não da SECADI, mas do MEC como um todo, com as diretrizes dessa política; ou com a baixa capacidade de gerência da SEPPIR sobre o órgão executor dessa e das demais políticas que coordenaria, ou mesmo a ausência de um modelo de implementação, uma vez que os parâmetros e diretrizes estão bastante definidos na legislação, mas os mecanismos e estratégias de ação não estão bem delimitados e tampouco são assertivos. 
O cenário atual é bastante desanimador, pois: i) órgãos, como o MEC ao estabelecerem programas que dialogam com determinado problema, julgam que o combatem, pela simples existência de uma única ação; ii) o órgão responsável, a SEPPIR, não possui condições de exercer efetivamente essa responsabilidade; iii) os movimentos sociais negros, que antes demandavam pela obrigatoriedade, agora demandam pela efetivação da obrigatoriedade; iv) as universidades ainda podem afirmar que inserem a história afro-brasileira ao apresentar a população negra como objeto de estudo, não necessariamente sujeito de conhecimento; v) as escolas permanecem, no conjunto de demandas e matérias, aliados a falta de estrutura e conhecimento, argumentando para a continuidade da oferta de conteúdos que não contemplam a história do País ou a da população negra.

Por fim, é possível indicar que para que essa política seja efetiva e aconteça pela ação, e não pela inação governamental, é importante desenvolver mecanismos que possibilitem que sua construção seja uma tarefa das instituições de ensino, e não dos professores simpáticos; dos órgãos responsáveis, e não dos técnicos engajados, e que a estrutura dessas ações constituam a base de projeto de país que se compromete com a educação e o combate ao racismo. 


\section{Referências}

ALAGOAS. Lei no 6.542, de 7 de dezembro de 2004. Disponível em: <http://www.gabinetecivil.al.gov.br/legislacao/leis/leis-ordinarias/ 2004/lei-ordinaria-6542>. Acesso em: 15 nov. 2016.

BAHIA. Constituição do Estado da Bahia, de 5 de outubro de 1989. Disponível em: <http://www2.senado.leg.br/bdsf/handle/ id/70433>. Acesso em: 28 mar. 2017.

BARBOSA, Márcio (Org.).FrenteNegra Brasileira: depoimentos. São Paulo: Quilombhoje, 1998.

BRAGA, Maria Lúcia de Santana; SILVEIRA, Maria Helena Vargas da (Org.). O Programa Diversidade na Universidade e a Construção de uma Política Educacional Anti-racista. Brasília, DF: Secretaria de Educação Continuada, Alfabetização e Diversidade; UNESCO, 2007.

BRASIL. Constituição da República Federativa do Brasil de 1988. 1988. Disponível em: <http://www.planalto. gov.br/ ccivil_03/constituicao/constitui\%C3\%A7ao.htm>. Acesso em: 13 jan. 2011.

. Decreto no 6.428, de 14 de abril de 2008. Altera o Decreto $n^{\circ} 6.170$, de 25 de julho de 2007, que dispõe sobre as 
normas relativas às transferências de recursos da União mediante convênios e contratos de repasse. Disponível em: <http://www. planalto.gov.br/ccivil_03/_ato2007-2010/2008/decreto/d6428. htm>. Acesso em: 5 mar. 2016.

\section{- Decreto no 5.622, de 19 de dezembro de 2005.}

Regulamenta o art. 80 da Lei no 9.394, de 20 de dezembro de 1996, que estabelece as diretrizes e bases da educação nacional. Disponível em: <http://portal.mec.gov.br/seed/arquivos/pdf/ dec_5622.pdf >. Acesso em: 3 de mar. 2017.2005a.

. Decreto no 1.819, de 16 de fevereiro de 1996.

Disciplina as transferências de recursos da União por intermédio de instituições e agências financeiras oficiais federais e dá outras providências. Disponível em: <http://www.planalto.gov.br/ccivil 03/decreto/1996/D1819.htm>. Acesso em: 20 abr. 2016. 1996a.

. Decreto no 6.170, de 25 de julho de 2007. Dispõe sobre as normas relativas às transferências de recursos da União mediante convênios e contratos de repasse, e dá outras providências. Disponível em: <http://www.planalto.gov.br/ccivil_03/_ato20072010/2007/decreto/d6170.htm>. Acesso em: 5 mar. 2016.

. Lei no 5.465, de 3 de julho de 1968. (REVOGADA). Dispõe sobre o preenchimento de vagas nos estabelecimentos de ensino agrícola. Disponível em: <https://www.planalto.gov.br/ ccivil_03/leis/1950-1969/15465.htm.>. Acesso em: 3 jan. 2013. 1968a.

. Decreto no 6.872, de 4 de junho de 2009. Aprova o Plano Nacional de Promoção da Igualdade Racial - PLANAPIR, e institui o seu Comitê de Articulação e Monitoramento. Disponível 
em: <http://www.planalto.gov.br/ccivil_03/_Ato2007-2010/ 2009/Decreto/D6872.htm>. Acesso em: 3 jan. 2013.2009a.

. Decreto no 4.228, de 13 de maio de 2002. Institui, no âmbito da Administração Pública Federal, o Programa Nacional de Ações Afirmativas e dá outras providências. Disponível em: <http://www.planalto.gov.br/ccivil_03/decreto/2002/D4228. htm>. Acesso em: 3 jan. 2013.

. Decreto no 1.904, de 13 de maio de 1996. Revogado pelo Decreto no 4.229, de 13 de maio de 2002. Institui o Programa Nacional de Direitos Humanos - PNDH. Disponível em: <http:// www.planalto.gov.br/ccivil_03/decreto/d1904.htm>. Acesso em: 3 mar. 2017. 1996b.

. Decreto no 8.136, de 5 de novembro de 2013. Aprova o regulamento do Sistema Nacional de Promoção da Igualdade Racial - Sinapir, instituído pela Lei no 12.288, de 20 de julho de 2010. Disponível em: <http://www.planalto.gov.br/ccivil_03/_Ato20112014/2013/Decreto/D8136.htm>. Acesso em: 3 mar. 2017.

. Decreto no 8, de 9 de novembro de 2005. Institui Grupo de Trabalho Interministerial - GTI para elaborar proposta de formulação do Plano Nacional de Políticas de Promoção da Igualdade Racial, e dá outras providências. Disponível em: $<$ http://legis.senado.gov.br/legislacao/ListaTextoIntegral.action? $\mathrm{id}=232168$ \&norma $=253275>$. Acesso em: 3 mar. 2017. $2005 \mathrm{~b}$.

. Decreto no 4.886, de 20 de novembro de 2003. Institui a Política Nacional de Promoção da Igualdade Racial - PNPIR e dá outras providências. Disponível em: <http://www.planalto. 
gov.br/ccivil_03/decreto/2003/D4886.htm>. Acesso em: 3 jan. 2013. 2003a.

. Lei no 12.711, de 29 de agosto de 2012. Dispõe sobre o ingresso nas universidades federais e nas instituições federais de ensino técnico de nível médio e dá outras providências. Disponível em: <http://www.planalto.gov.br/ccivil_03/_Ato2011-2014/ 2012/Lei/L12711.htm>. Acesso em: 3 jan. 2013.

. Lei $\mathrm{n}^{\circ}$ 5.692, de 11 de agosto de 1971. Fixa Diretrizes e Bases para o ensino de $1^{\circ}$ e $2^{\circ}$ graus, e dá outras providências. Disponível em: <http://www.planalto.gov.br/ccivil_03/leis/ 15692.htm>. Acesso em: 21 jul. 2011.

. Lei no 8.112, de 11 de dezembro de 1990. Dispõe sobre o regime jurídico dos servidores públicos civis da União, das autarquias e das fundações públicas federais. Disponível em: <https://www.planalto.gov.br/ccivil_03/leis/L8112cons.htm>. Acesso em: 20 out. 2016.

- Ministério da Educação. Fundo Nacional de Desenvolvimento da Educação, Conselho Deliberativo. Resolução no 14, de 28 de abril de 2008. Estabelece critérios para a assistência financeira com o objetivo de fomentar ações voltadas à formação inicial e continuada de professores de educação básica e a elaboração de material didático específico no âmbito do Programa de Ações Afirmativas para a População Negra nas Instituições Federais e Estaduais de Educação Superior (UNIAFRO). Diário Oficial da União. Brasília, DF, 29 abr. 2008. Seção 1. 2008 b.

. Ministério da Educação. Secretaria de Educação Superior Departamento de Políticas da Educação Superior. Edital no 1, de 
5 de abril de 2005. Diário Oficial da União. Brasília, DF, 29 abr. 2005. Edição Número 81.2005c.

. Ministério da Educação, Secretaria de Educação Superior Departamento de Políticas da Educação Superior. Portaria Conjunta $n^{\circ} 42$, de $1^{\circ}$ de junho de 2005. Diário Oficial da União. Brasília, DF, 3 jun. 2005. Seção 2. 2005 d.

- Ministério da Educação. Secretaria de Educação Continuada, Alfabetização e Diversidade. Edital de Convocação no 18, de 13 de julho de 2009. Diário Oficial da União. Brasília, DF, 14 jul. 2009. Seção 3. 2009 b.

. Lei no 10.639, de 9 de janeiro de 2003. Altera Lei $\mathrm{n}^{\circ}$ 9.394, de 20 de dezembro de 1996, que estabelece as diretrizes e bases da educação nacional, para incluir no currículo oficial da Rede de Ensino a obrigatoriedade da temática "História e Cultura Afro-Brasileira”, e dá outras providências. Disponível em: <http:// www.planalto.gov.br/ccivil/LEIS/2003/L10.639.htm>. Acesso em: 21 jul. 2011. 2003b.

Lei no 8.213, de 24 de julho de 1991. Dispõe sobre os Planos de Benefícios da Previdência Social e dá outras providências. Disponível em: <http://www.planalto.gov.br/ccivil_03/leis/L8213 cons.htm>. Acesso em: 20 out. 2016.

. Lei no 12.288, de 20 de julho de 2010. Institui o Estatuto da Igualdade Racial; altera as Leis $\mathrm{n}^{\text {os }} 7.716$, de 5 de janeiro de 1989, 9.029, de 13 de abril de 1995, 7.347, de 24 de julho de 1985, e 10.778, de 24 de novembro de 2003. Disponível em: <http://www.planalto.gov.br/ccivil_03/_Ato2007-2010/2010/ Lei/L12288.htm>. Acesso em: 21 jul. 2011. 
. Lei no 8.666, de 21 de junho de 1993. Regulamenta o art. 37, inciso XXI, da Constituição Federal, institui normas para licitações e contratos da Administração Pública e dá outras providências. Disponível em: <https://www.planalto.gov.br/ ccivil 03/Leis/L8666cons.htm>. Acesso em: 20 out. 2016.

. Lei no 11.645, de 10 de março de 2008. Altera a Lei $\mathrm{n}^{\circ}$ 9.394, de 20 de dezembro de 1996, modificada pela Lei no 10.639, de 9 de janeiro de 2003, que estabelece as diretrizes e bases da educação nacional, para incluir no currículo oficial da rede de ensino a obrigatoriedade da temática História e Cultura AfroBrasileira e Indígena. Disponível em: <https://www.planalto.gov. br/ccivil_03/_ato2007-2010/2008/lei/111645.htm.>. Acesso em: 3 jan. 2013. 2008c.

. Lei no 5.540, de 28 de novembro de 1968. Fixa normas de organização e funcionamento do ensino superior e sua articulação com a escola média, e dá outras providências. Disponível em: <www.planalto.gov.br/ccivil_03/leis/15540.htm.>. Acesso em: 21 jul. 2011. 1968 b.

. Lei no 12.527, de 18 de novembro de 2011 . Regula o acesso a informações previsto no inciso XXXIII do art. 5\%, no inciso II do $\int 3^{\circ}$ do art. 37 e no $\$ 2^{\circ}$ do art. 216 da Constituição Federal; altera a Lei no 8.112, de 11 de dezembro de 1990; revoga a Lei $n^{\circ} 11.111$, de 5 de maio de 2005, e dispositivos da Lei no 8.159, de 8 de janeiro de 1991; e dá outras providências. Disponível em: <http://www.planalto.gov.br/ccivil_03/_ato2011-2014/2011/ lei/112527.htm>. Acesso em: 3 mar. 2017.

. Lei no 9.504, de 30 de setembro de 1997. Estabelece normas para as eleições. Disponível em: <http://www.planalto. gov.br/ccivil_03/leis/L9504.htm>. Acesso em: 20 out. 2016. 
. Ministério da Educação. Plano Nacional de Educação

2001-2010. Brasília, DF: [s.n.], 2000. Disponível em: <http:// portal.mec.gov.br/arquivos/pdf/pne.pdf $>$. Acesso em: 13 jan. 2011.

- Ministério do Planejamento, Orçamento e Gestão. Secretaria de Planejamento e Investimentos Estratégicos. Plano Plurianual 2004-2007: mensagem presidencial. Brasília, DF: Ministério do Planejamento, Orçamento e Gestão. Secretaria de Planejamento e Investimentos Estratégicos, 2003c.

- Ministério do Planejamento, Orçamento e Gestão. Secretaria de Planejamento e Investimentos Estratégicos. Plano Plurianual 2008-2011: projeto de lei. Brasília, DF: Ministério do Planejamento, Orçamento e Gestão, Secretaria de Planejamento e Investimentos Estratégicos, 2007.

. Ministério da Educação. Portaria Normativa no 2, de 19 de janeiro de 2007. Dispõe sobre os procedimentos de regulação e avaliação da educação superior na modalidade a distância. Disponível em: <http://portal.mec.gov.br/seed/arquivos/pdf/ legislacao/portaria2.pdf>. Acesso em: 3 mar. 2017.

. Ministério da Educação. Secretaria Especial de Políticas de Promoção de Igualdade Racial. Plano Nacional de Implementação das Diretrizes Curriculares Nacionais para a Educação das Relações Étnico-raciais e para o Ensino da História e Cultura Afro-brasileira e Africana. Brasília, DF: [s.n], 2009c.

- Ministério do Planejamento, Orçamento e Gestão. Secretaria de Planejamento e Investimentos Estratégicos. Plano Plurianual 2012-2015: projeto de lei. Brasília, DF: Ministério do 
Planejamento, Orçamento e Gestão. Secretaria de Planejamento e Investimentos Estratégicos, 2011.

\section{. Resolução CNE/CP no 1, de 17 de junho de 2004.}

Institui Diretrizes Curriculares Nacionais para a Educação das Relações Étnico-Raciais e para o Ensino de História e Cultura AfroBrasileira e Africana. Disponível em: <http://portal.mec.gov.br/ cne/arquivos/pdf/res012004.pdf>. Acesso em: 20 out. 2016.

CENTRO DE EDUCAÇÃO A DISTÂNCIA (CEAD). (Universidade de Brasília). Projeto Básico: educação africanidades Brasil. Brasília, DF, 2006. Não publicado.

DEGLER, Carl N. Nem Preto nem Branco: escravidão e relações raciais no Brasil e E.U.A. Rio de Janeiro: Ed. Labor, 1976.

DIAS, Lucimar Rosa. Quantos passos já foram dados? A questão de raça nas leis educacionais - da LDB de 1961 à Lei 10.639 de 2003. In: ROMÃO, Jeruse (Org.). História da Educação do Negro e Outras Histórias. Brasília, DF: Ministério da Educação/Secretaria de Educação Continuada, Alfabetização e Diversidade, 2005.

DOMINGUES, Petrônio. Movimento negro brasileiro: alguns apontamentos históricos. Tempo, v. 12, n. 23, 2007. Disponível em: <http://www.scielo.br/pdf/tem/v12n23/v12n23a07.>. Acesso em: 27 set. 2016 .

DRAIBE, Sônia Miriam. As políticas sociais brasileiras: diagnósticos e perspectivas. In: . Para a Década de 90: prioridades e perspectivas de políticas públicas. Políticas Sociais e Organização do Trabalho. v. 4, Brasília, DF: IPEA; IPLAN, 1990. 
FRASER, Nancy. From Redistribution to Recognition? Dilemmas of Justice in a 'Post-Socialist' Age. New Left Review, n. 212, jul./ ago. 1995.

GRUPO DE ESTUDOS MULTIDISCIPLINARES DA AÇÃO AFIRMATIVA (GEMAA). Grupo de Estudos Multidisciplinares da Ação Afirmativa, Legislações e resoluções sobre as ações afirmativas no Brasil. [20--]. Resumo de Legislações Antirracistas. IESP-UERJ. Disponível em: <http://gemaa.iesp. uerj.br/dados/legislacao.htm>. Acesso em: 15 nov. 2016.

GIL, Antonio Carlos. Métodos e Técnicas de Pesquisa Social. 6. ed. São Paulo: Atlas, 2008.

INSTITUTO NACIONAL DE ESTUDOS E PESQUISAS EDUCACIONAIS ANÍSIO TEIXEIRA (INEP). 2011. Censo da Educação Básica: 2010 - resumo técnico. Brasília, DF: INEP, 2011.

INSTITUTO BRASILEIRO DE GEOGRAFIA E ESTATÍSTICA (IBGE). Características da População e Domicílios. 2010. Disponível em: <http://www.ibge.gov.br/home/estatistica/ populacao/censo2010/caracteristicas_da_populacao/tabelas pdf/tab1.pdf. $>$. Acesso em: 16 fev. 2017.

- Censo Demográfico MEC/INEP/Censo Escolar 1980/2000. Brasília, DF: Edudata Brasil. [20--]. Disponível em: $<$ http://seriesestatisticas.ibge.gov.br/series.aspx?vcodigo=SEE17>. Acesso em: 16 fev. 2017.

- Pesquisa Nacional por Amostra de Domicílios PNAD. 2007. Disponível em: <http://www.ibge.gov.br/home/ estatistica/populacao/trabalhoerendimento/pnad2007/default. shtm>. Acesso em: 3 mar. 2017. 
JACCOUD, Luciana (Org.). A Construção de uma Política de Promoção da Igualdade Racial: uma análise dos últimos 20 anos. Brasília, DF: IPEA, 2009a.

.Igualdade Racial.In:Políticas Sociais: acompanhamento e análise, v. 3, n. 17, Brasília, DF: IPEA, 2009b. (Coleção Vinte Anos da Constituição).

JACCOUD, Luciana; BEGHIN, Nathalie. Desigualdades Raciais no Brasil: um balanço da intervenção governamental. Brasília, DF: IPEA, 2002.

JANNUZZI, Paulo de Martino. Indicadores para diagnóstico, monitoramento e avaliação de programas sociais no Brasil. Revista do Serviço Público, Brasília, DF, v. 56, n. 2, 2005.

JANNUZZI, P. de M.; MIRANDA, W. L.; SILVA, D. S. G. da. Análise Multicritério e Tomada de Decisão em Políticas Públicas: aspectos metodológicos, aplicativo operacional e aplicações. Revista Informática Pública, Belo Horizonte, ano II, p. 69-87, 2009.

KINGDON, John. Agendas, Alternatives and Public Policies. 2. ed. Boston: Little Brown, 1995.

LIMA, Márcia. Desigualdades Raciais e Políticas Públicas: ações afirmativas no governo Lula. Novos Estudos - CEBRAP, São Paulo, n. 87, 2010. Disponível em: <http://www.scielo.br/scielo. php?script=sci_arttext\&pid=S0101-33002010000200005>. Acesso em: 6 jun. 2012.

MANIFESTO em Defesa... Brasília, DF: [s.n], 2009. Disponível em: <https://avaliacaodurban2009.wordpress.com/2009/06/30/ 
conapir-manifesto-em-defesa-dos-direitos-e-da-autonomiapolitica-da-populacao-negra/>. Acesso em: 16 fev. 2017.

MARCHA Zumbi... Brasília, DF: [s.n], 1995. Disponível em: <http://memorialdademocracia.com.br/card/marcha-zumbireune-30-mil-em-brasilia/docset/910 > . Acesso em: 16 fev. 2017.

MINISTÉRIO DA EDUCAÇÃO (Brasil). Secretaria de Educação Continuada, Alfabetização e Diversidade. Gênero e Diversidade Sexual na Escola: reconhecer diferenças e superar preconceitos. Brasília, DF: SECAD, 2007. (Cadernos).

. Nota Técnica no 14/2009/CGDI/DEDI/SECAD/ MEC. Brasília, DF. Não publicado.

. Nota Técnica no 23/2009/CGDI/DEDI/SECAD/ MEC. Brasília, DF. Não publicado.

. Nota Técnica no 24/2009/CGDI/DEDI/SECAD/ MEC. Brasília, DF. Não publicado.

- Nota Técnica no 7/2010/CGDI/DEDI/SECAD/ MEC. Brasília, DF. Não publicado.

. Orientações e Ações para a Educação das Relações Étnico-Raciais. Brasília, DF: SECADI, 2006. Disponível em: <portal.mec.gov.br/dmdocuments/orientacoes_etnicoraciais. pdf>. Acesso em: 15 fev. 2017.

- Parecer CNE/CP 003/2004. Brasília, DF. Não publicado.

. Parecer Técnico no 03/2008/CGDI/DEDI/SECAD/

MEC. Brasília, DF. Não publicado. 
MEC. Brasília, DF. Não publicado.

. Parecer Técnico n 06/2008/CGDI/DEDI/SECAD/

MEC. Brasília, DF. Não publicado.

. Parecer Técnico nº 07/2008/CGDI/DEDI/SECAD/

MEC. Brasília, DF. Não publicado.

. Parecer Técnico no 10/2008/CGDI/DEDI/SECAD/

MEC. Brasília, DF. Não publicado.

. Parecer Técnico no 14/2008/CGDI/DEDI/SECAD/

MEC. Brasília, DF. Não publicado.

. Parecer Técnico no 15/2008/CGDI/DEDI/SECAD/

MEC. Brasília, DF. Não publicado.

. Parecer Técnico no 16/2008/CGDI/DEDI/SECAD/

MEC. Brasília, DF. Não publicado.

. Parecer Técnico no 18/2008/CGDI/DEDI/SECAD/

MEC. Brasília, DF. Não publicado.

. Parecer Técnico n 20/2008/CGDI/DEDI/SECAD/

MEC. Brasília, DF. Não publicado.

. Parecer Técnico n 21/2008/CGDI/DEDI/SECAD/

MEC. Brasília, DF. Não publicado.

. Parecer Técnico no 22/2008/CGDI/DEDI/SECAD/

MEC. Brasília, DF. Não publicado. 
MEC. Brasília, DF. Não publicado. . Parecer Técnico no 24/2008/CGDI/DEDI/SECAD/ MEC. Brasília, DF. Não publicado. . Parecer Técnico n 25/2008/CGDI/DEDI/SECAD/ MEC. Brasília, DF. Não publicado. . Parecer Técnico no 26/2008/CGDI/DEDI/SECAD/ MEC. Brasília, DF. Não publicado. . Parecer Técnico n 27/2008/CGDI/DEDI/SECAD/ MEC. Brasília, DF. Não publicado. . Parecer Técnico no 31/2008/CGDI/DEDI/SECAD/ MEC. Brasília, DF. Não publicado. . Parecer Técnico no 34/2008/CGDI/DEDI/SECAD/ MEC. Brasília, DF. Não publicado. . Parecer Técnico no 35/2008/CGDI/DEDI/SECAD/ MEC. Brasília, DF. Não publicado. . Parecer Técnico n 36/2008/CGDI/DEDI/SECAD/ MEC. Brasília, DF. Não publicado. . Parecer Técnico n 37/2008/CGDI/DEDI/SECAD/ MEC. Brasília, DF. Não publicado. . Parecer Técnico no 08/2009/CGDI/DEDI/SECAD/ MEC. Brasília, DF. Não publicado. 
. Parecer Técnico no 61/2009/CGDI/DEDI/SECAD/

MEC. Brasília,DF. Não publicado.

. Parecer Técnico no 02/2010/CGDI/DEDI/SECAD/

MEC. Brasília, DF. Não publicado.

- Parecer Técnico no 21/2011/CGERER/DPECD/

SECADI/MEC. Brasília, DF. Não publicado.

. Parecer Técnico no 72/2011/CGERER/DPECAD/

SECADI/MEC. Brasília, DF. Não publicado.

.Parecer Técnico no 16/2012/CGERER/DPECIRER/

SECADI/MEC. Brasília, DF. Não publicado.

.Parecer Técnico no 19/2012/CGERER/DPECIRER/

SECADI/MEC. Brasília, DF. Não publicado.

.Parecer Técnico n 20/2012/CGERER/DPECIRER/

SECADI/MEC. Brasília, DF. Não publicado.

.Parecer Técnico no 37 /2012/CGERER/DPECIRER/

SECADI/MEC. Brasília, DF. Não publicado.

.Parecer Técnico no 38/2012/CGERER/DPECIRER/

SECADI/MEC. Brasília, DF. Não publicado.

. Parecer Técnico no 41/2012/CGERER/DPECAD/

SECADI/MEC. Brasília, DF. Não publicado.

.Parecer Técnico no 44/2012/CGERER/DPECIRER/

SECADI/MEC. Brasília, DF. Não publicado. 
. Planilha Financeira Educação Africandades Brasil. Brasília, DF, 2006. Não publicado.

. Planilha Relação das Ofertas de Cursos da CGDI no Ministério da Educação. Programa UNIAFRO por Estado e por Edital. Brasília, DF, 2012. Não publicado.

- Planilha Educação para relações étnico-raciais. Brasília, DF, 2012.

. Planilha Dados gerais UNIAFRO. Brasília, DF, 2012. Não publicado.

Relatório Parcial - Uniafro 2006 - UEL. Brasília, DF. Não publicado.

. Relatório Parcial - Uniafro 2006 - UFAL. Brasília, DF. Não publicado.

. Relatório Parcial - Uniafro 2006 - UFMG. Brasília, DF. Não publicado.

. Relatório Parcial - Uniafro 2006 - UFPI. Brasília, DF. Não publicado.

. Relatório Parcial - Uniafro 2006 - UFRJ. Brasília, DF. Não publicado.

. Relatório Parcial - Uniafro 2006 - UFU. Brasília, DF. Não publicado.

. Instituto Nacional de Estudos e Pesquisas Educacionais Anísio Teixeira. Resumo Técnico - Censo Escolar 2010. 2010, 
Disponível em: <http://download.inep.gov.br/educacao_basica/ censo_escolar/resumos_tecnicos/divulgacao_censo2010_ revisao_04022011.pdf.>. Acesso em: 15 nov. 2016.

MOREIRA, Antônio Flávio Barbosa. Currículos e Programas no Brasil. Campinas: Papirus, 1990.

(Org.). Currículo: questões atuais. Campinas: Papirus, 1997.

MUNANGA, Kabenguele. Rediscutindo a Mestiçagem no Brasil. São Paulo: Autêntica, 2004.

NAÇÕES UNIDAS. Declaração e Programa de Ação adotados na III Conferência Mundial de Combate ao Racismo, Discriminação Racial, Discriminação Racial, Xenofobia e Intolerância Correlata. 31 de agosto a 8 de setembro de 2001. 2001. Durban, África do Sul. Disponível em: <goo.gl/E7nBMf $\rangle$. Acesso em: 3 mar. 2017.

RIOS, Flavia. O Protesto Negro no Brasil Contemporâneo (1978-2010). São Paulo: Lua Nova, 2012.

SANTOS, Sales Augusto dos (Org.). Ações Afirmativas e Combate ao Racismo nas Américas. Brasília: MEC; UNESCO, 2005.

. Políticas Públicas de Promoção da Igualdade Racial, Questão Racial, Mercado de Trabalho e Justiça Trabalhista. Revista TST, Brasília, DF, v. 76, n. 3, jul./set. 2010.

; MORENO, João Vitor; BERTÚLIO, Dora Lúcia. O Processo de Aprovação do Estatuto da Igualdade Racial, Lei no 12.288, de 20 de julho de 2010. Brasília, DF: INESC, 2011. 
SANTOS, Sônia Querino dos Santos; MACHADO, Vera Lúcia de Carvalho. Políticas públicas educacionais: antigas reivindicações, conquistas (Lei 10.639) e novos desafios. Ensaio: avaliação e políticas públicas em Educação, Rio de Janeiro, v. 16, n. 58, jan./mar. 2008. Disponível em: <http://www.scielo.br/scielo. php?script=sci_arttext\&pid=S0104-40362008000100007\&lng=e n\&nrm=iso >. Acesso em: 6 jun. 2012. http://dx.doi.org/10.1590/ S0104-40362008000100007.

SANTOS, Wanderley Guilherme dos. Do Laissez-faire Repressivo à Cidadania em Recesso. A política social autoritária e a cidadania emergente. In: Cidadania e Justiça - a política social na ordem brasileira. 2. ed. Rio de Janeiro: Ed. Campus, 1987. cap. 4;5.

SECRETARIA DE EDUCAÇÃO CONTINUADA (SECAD). Edital de Resultado de Julgamento n. 1, de 31 de maio de 2006. Diário Oficial da União. Brasília, DF, 2 jun. 2006. Seção 3, p. 44.

. Edital n. 25, de 2 de setembro de 2009. Diário Oficial da União. Brasília, DF, 4 set. 2009. Seção 3, p. 39.

. Portaria Conjunta no 1 , de 12 de setembro de 2008. Diário Oficial da União. Brasília, DF, 15 set. 2008. Seção 1. p. 11.

SECRETARIA DE EDUCAÇÃO SUPERIOR (SESu). Portaria no 94, de 8 de dezembro de 2005. Diário Oficial da União. Brasília, DF, 9 dez. 2005. Seção 1, p. 25, 2005a.

. Resultado de Julgamento n. 1. Edital, de 6 de julho de 2005. Diário Oficial da União. Brasília, DF, 8 jul. 2005. Seção 3, p. 13, 2005b.

- Portaria no 92, de 30 de novembro de 2005. Diário Oficial da União. Brasília, DF, 1 dez. 2005. Seção 1, p. 13, 2005c. 
SECRETARIA DE POLÍTICAS DE PROMOÇÃO DA IGUALDADE RACIAL (SEPPIR). Nota de Esclarecimento Estatuto da Igualdade Racial, de 3 de setembro de 2009. Brasília, DF: [s.n.], 2009.

SILVÉRIO, Valter Robério. Políticas Educacionais para AfroBrasileiros e Indígenas. In: RAMOS, Marise Nogueira et al. (Org.). Diversidade na Educação: reflexões e experiências. Brasília: Secretaria de Educação Média e Tecnologia, 2003.

SKIDMORE, Thomas Elliot. Pretono Branco: raça e nacionalidade no pensamento brasileiro. Tradução de Raul de Sá Barbosa. Rio de Janeiro: Paz e Terra, 1976.

SODRÉ, Muniz. Claros e Escuros: identidade, povo e mídia no Brasil. Petrópolis: Vozes, 1999.

SOUZA, Celina. Estado da Arte da Pesquisa em Políticas Públicas. In: Hochman, Gilberto; ARRETCHE, Marta; MARQUES, Eduardo. Políticas Públicas no Brasil. Rio de Janeiro: Ed. Fiocruz, 2007.

THEODORO, Mário; DELGADO, Guilherme. Política social: universalização ou focalização - subsídios para o debate. Políticas sociais - acompanhamento e análise, n. 7, p. 122-126, ago. 2003.

WINANT, Howard. The World is a Ghetto: race and democracy since World War II. New York: Basic Books, 2001.

YOUNG, Iris Marion. Unruly Categories: a critique of Nancy Fraser's Dual Systems Theory, New Left Review, Londres, no 222, 1997. 